\title{
WestVirginiaUniversity
}

THE RESEARCH REPOSITORY @ WVU

Graduate Theses, Dissertations, and Problem Reports

2010

\section{Satisfaction of contract poultry producers in Virginia and West Virginia}

Christina L. Richmond

West Virginia University

Follow this and additional works at: https://researchrepository.wvu.edu/etd

\section{Recommended Citation}

Richmond, Christina L., "Satisfaction of contract poultry producers in Virginia and West Virginia" (2010). Graduate Theses, Dissertations, and Problem Reports. 2974.

https://researchrepository.wvu.edu/etd/2974

This Thesis is protected by copyright and/or related rights. It has been brought to you by the The Research Repository @ WVU with permission from the rights-holder(s). You are free to use this Thesis in any way that is permitted by the copyright and related rights legislation that applies to your use. For other uses you must obtain permission from the rights-holder(s) directly, unless additional rights are indicated by a Creative Commons license in the record and/ or on the work itself. This Thesis has been accepted for inclusion in WVU Graduate Theses, Dissertations, and Problem Reports collection by an authorized administrator of The Research Repository @ WVU. For more information, please contact researchrepository@mail.wvu.edu. 
Satisfaction of Contract Poultry Producers in Virginia and West Virginia

Christina L. Richmond

Thesis Submitted to the Davis College of Agriculture, Natural Resources and Design at West Virginia University in partial fulfillment of the requirements for the degree of

\author{
Master of Science \\ in \\ Agricultural and Extension Education \\ Deborah A. Boone, Ph.D., Chair \\ Harry N. Boone, Jr., Ph.D. \\ Joseph S. Moritz, III, Ph.D. \\ Division of Resource Management \\ Morgantown, West Virginia \\ 2010
}

Keywords: Contract Poultry Production, Poultry Producer Satisfaction 


\section{ABSTRACT}

Satisfaction of Contract Poultry Growers in Virginia and West Virginia Christina L. Richmond

This study investigated the satisfaction of contract poultry producers in West Virginia and Virginia using a mailed questionnaire. Producers were asked to provide feedback on their company, income, debt load and grower relations. Producers indicated they were satisfied with their business decision to raise contract poultry. Level of satisfaction was significantly different for producers in the two states. Producers who raise pullets or broiler breeders exhibited greater satisfaction that broiler producers. The income level of producers has increased, however more producers have indicated they are losing money. Producers showed high levels of satisfaction with their service personnel who come directly to their farm operations on a regular basis when compared to statements about company management, which showed lower levels of agreement with regard to satisfaction. 


\section{ACKNOWLEDGEMENTS}

This process could not have been completed without the help of many individuals. First and foremost, to the producers who took the time to respond to this survey, without your opinions I could not have completed this project. You not only helped me complete the requirements for my graduate work, you bring joy to my professional life working with many of you day to day.

Thank you to my Mom, you have never once told me there was something I couldn't accomplish and I appreciate that more than you will ever know.

To Jim, thanks for being my biggest cheerleader through this and letting me know that someone was proud of what I was doing.

To Dr. Debby Boone, I could not have gotten any luckier to get to know you and have your help in writing this thesis, I have learned so much and I could never thank you enough for putting up with me.

To Dr. Harry Boone, without your knowledge of SPSS and formatting knowledge this would never have gotten to where it is.

To Dr. Joe Mortiz, thank you for serving on my committee, your knowledge of the poultry industry was important to this process and your friendship has been priceless.

To Jeremy, Travis, and Rebecca, it has been a pleasure to get to know you guys and your help has been most appreciated and finally to Michael Harman, thanks for the comic relief and advice on how to write. 


\section{TABLE OF CONTENTS}

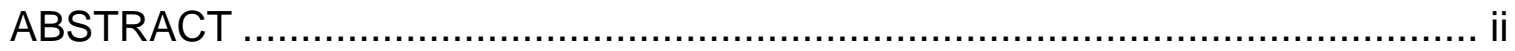

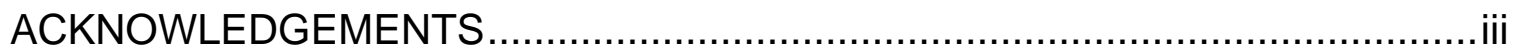

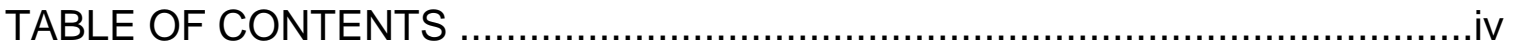

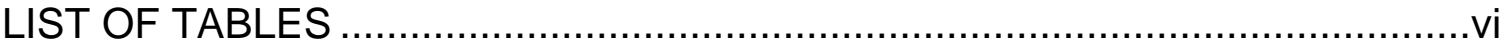

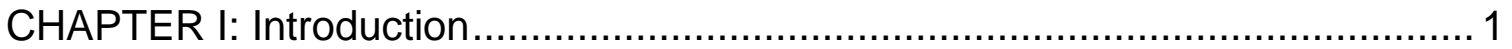

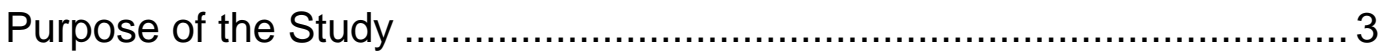

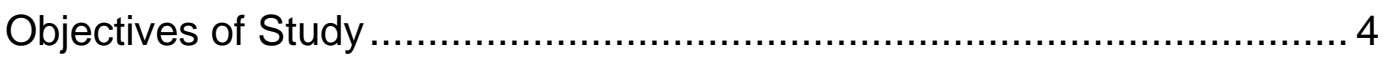

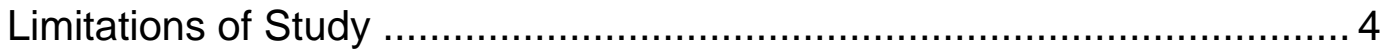

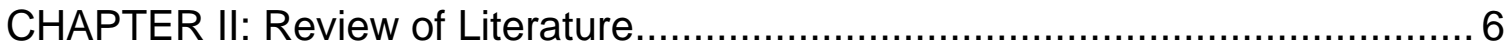

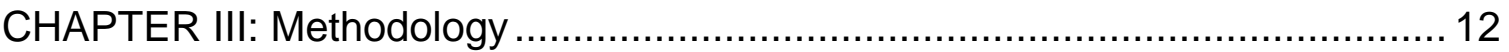

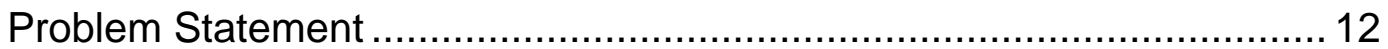

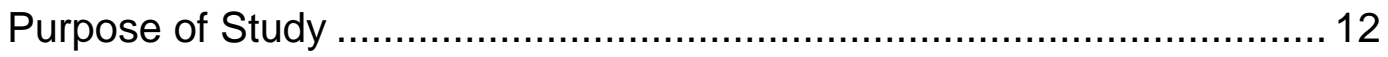

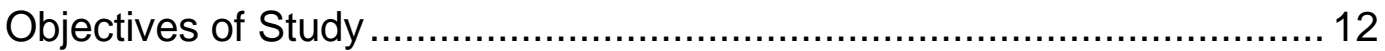

Research Design ............................................................... 13

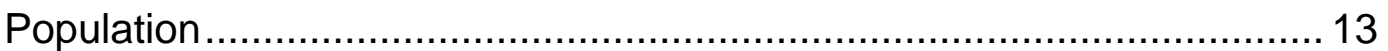

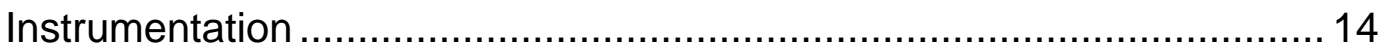

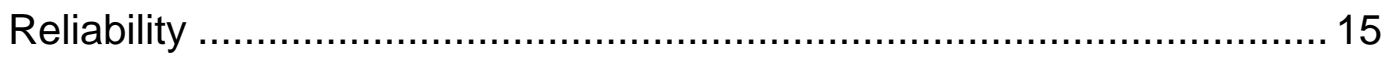

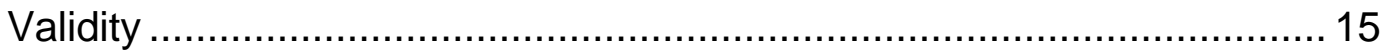

Data Collection Procedures ......................................................... 16 


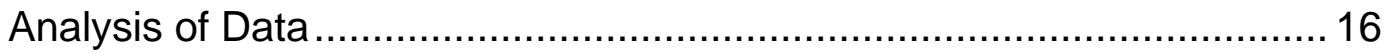

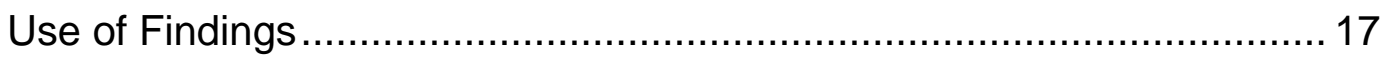

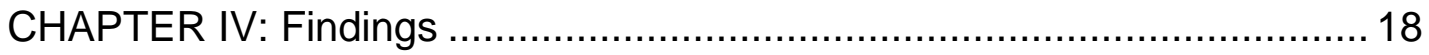

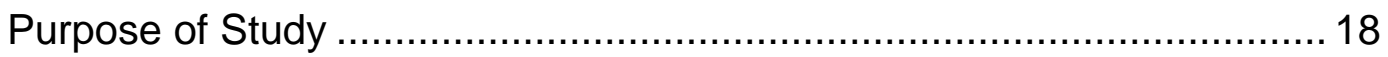

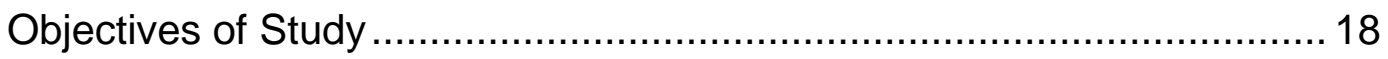

CHAPTER V: Summary, Conclusions, and Recommendations........................ 96

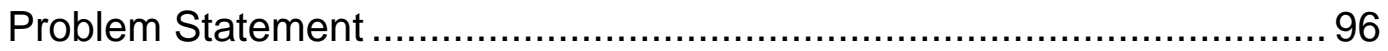

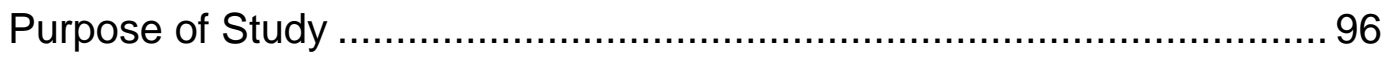

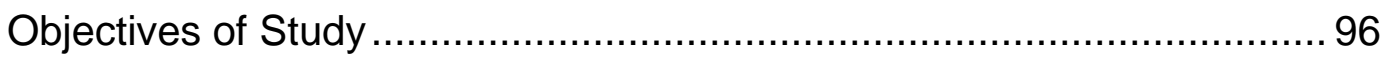

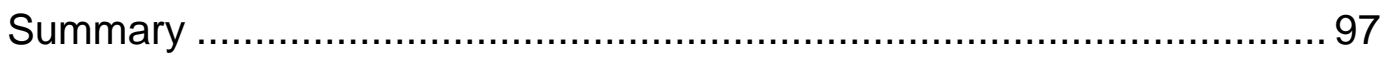

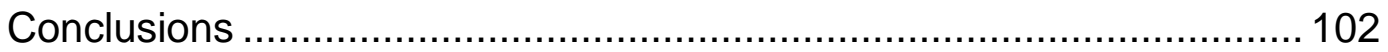

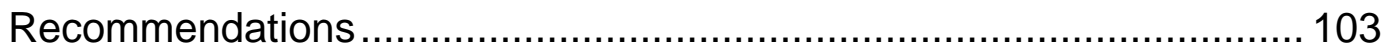

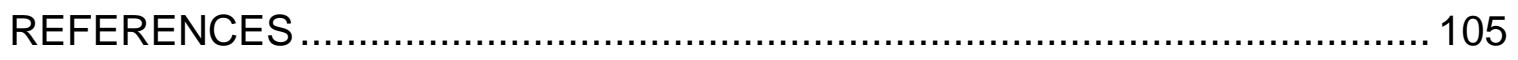

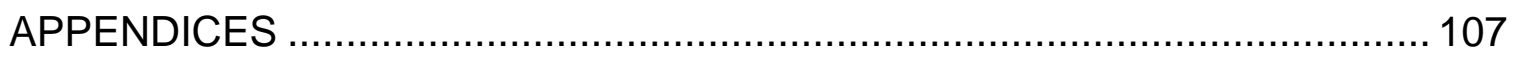

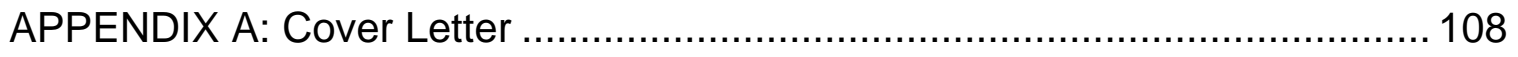

APPENDIX B: Follow-up Cover Letter ..................................................... 110

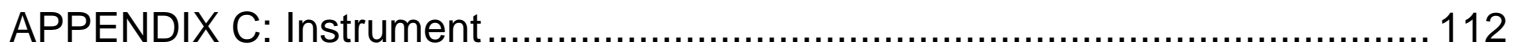

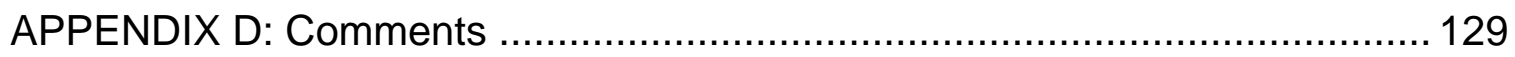

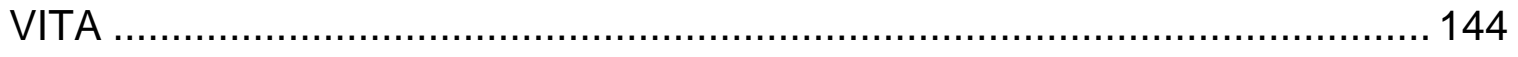




\section{LIST OF TABLES}

Table Title Page

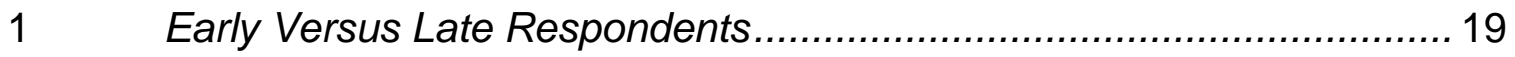

$2 \quad$ Poultry Operation Involved in Production ........................................ 20

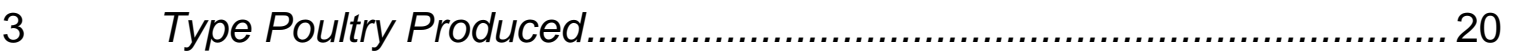

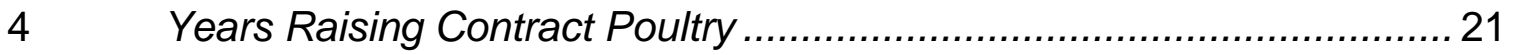

$5 \quad$ Employment Prior to Raising Poultry ............................................ 21

$6 \quad$ Reasons for Entering Poultry Profession ........................................ 23

$7 \quad$ Where Received Information About Income Expectations from

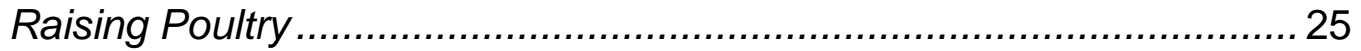

$8 \quad$ Farm Income

$9 \quad$ Off Farm Job Full Time or Part Time ................................................. 26

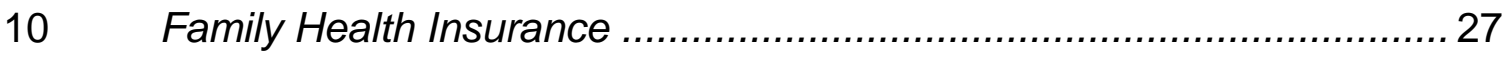

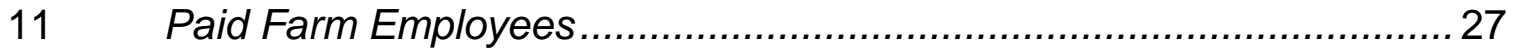

$12 \quad$ Hours Worked on Poultry Operation ................................................ 29

13 Producer Level of Agreement on Company Operations...................... 34

14 Producer Level of Agreement with Statements Related to Company and Service Person........................................................ 41

15 Have the Terms of Your Contract Been Changed to Increase Net

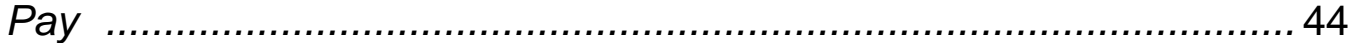

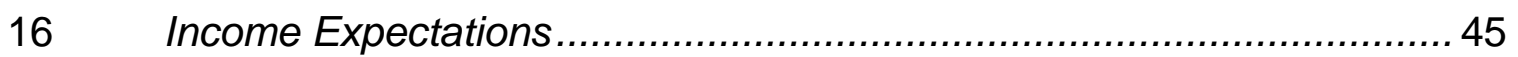

$17 \quad$ Reasons for Lower Income Expectations ....................................... 46

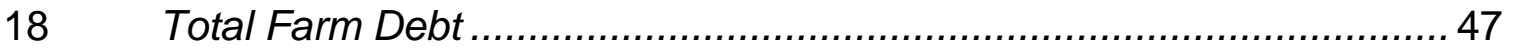

19 Percent of Farm Debt Owed on the Poultry Operation ....................... 48

$20 \quad$ Net Cash Flow from Poultry Operation 2008................................... 49 
21 Produce Crops or Livestock Other than Poultry Income ..................... 49

$22 \quad$ Percentage of Farm Income from Poultry in 2008........................... 50

$23 \quad$ Number of Times Over the Past Ten Flocks Producer was

Average or Better ........................................................................ 51

$24 \quad$ Average Number of Times Producer Settled Better than Average ........ 51

25 Producers Membership in Farm Organizations ............................... 52

$26 \quad$ Producer Satisfaction toward Poultry Business................................ 54

$27 \quad$ Producer Attitudes toward Integrator ................................................. 58

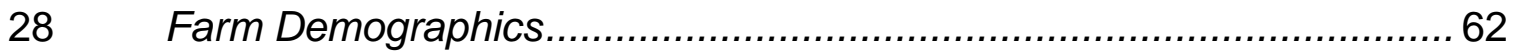

29 State of Residence and Gender of Respondents............................... 62

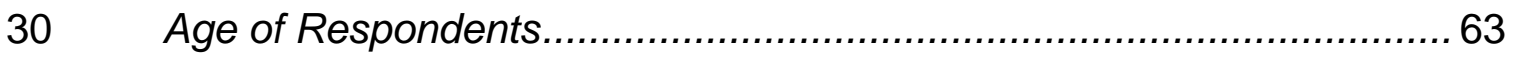

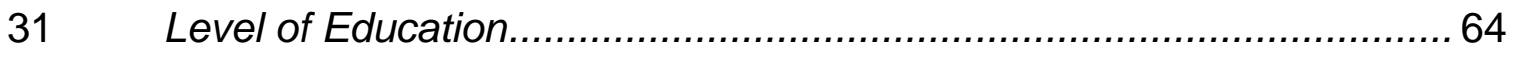

32 Comparison of Total Farm Debt in 2008 to Net Cash Flow from Poultry Production Income levels ...................................................... 67

33 Comparison of Total Farm Debt 2008 to Producer Age ...................... 70

34 Comparison of Satisfaction and Type of Poultry Produced .................. 72

35 Comparison of Satisfaction and Reason to Raise Poultry: to Make

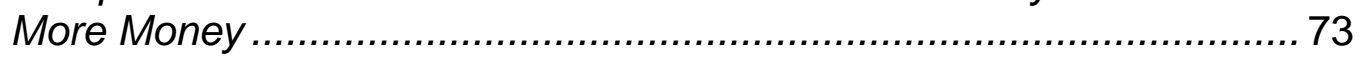

36 Comparison of Satisfaction and Reason for Raising Poultry: Retirement Income.................................................................... 75

37 Comparison of Satisfaction and Reason for Raising Poultry: Easy Financing

38 Comparison of Satisfaction and Reason for Raising Poultry: Financial Stability 79

39 Comparison of Satisfaction and Reason for Raising Poultry: Diversification of Farm Operation 
40 Comparison of Satisfaction and Reason for Raising Poultry:

Family Tradition

41 Comparison of Satisfaction and Reason for Raising Poultry: To be

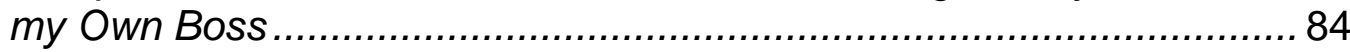

42 Comparison of Satisfaction and Reason for Raising Poultry: Other..... 85

$43 \quad$ Comparison of Satisfaction and Income Levels ................................ 88

44 Comparison of Producer Satisfaction and Debt Load ......................... 90

45 Comparison of Producer Satisfaction and State of Residence............. 92

$46 \quad$ Comparison of Producer Satisfaction by Gender .............................. 93

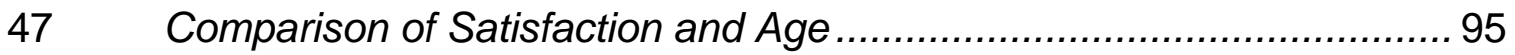




\section{CHAPTER I}

\section{Introduction}

Poultry is the number one agricultural industry in the states of Virginia and West Virginia with a combined yearly production of over 320 million broilers. The industry is important not only to the farmers who raise the birds but the local economies that are impacted by the industry (National Agriculture Statistics Service, 2007). The poultry industry provides employment for 2500 people in West Virginia and over 10,000 individuals in Virginia (Virginia Poultry Federation, 2007). There are 1100 contract poultry operations in Virginia and 350 in West Virginia (National Agriculture Statistics Service, 2007). These operations raise broilers, broiler breeders, pullets, turkeys and turkey breeders.

Commercial poultry production in these areas is under contract with local farmers. The company supplies the producers with the birds, feed, technical support and transportation. The producer in turn supplies the labor, housing, mortality management and most of the time, the utilities needed for the birds. According to Goodwin (2005), "the poultry industry represents the most vertically integrated sector of all US agriculture and food production" (p. 339). The typical broiler operation is considered small if they own less than four houses.

In the US, $45 \%$ of the contract producers have small operations that use older houses and are owned by older producers (MacDonald, 2008). Broiler production can be used as primary or supplemental income for producers who choose to contract and build houses (Cunningham, 2009B). Producers who 
contract poultry generally do so with financing for fifteen years with houses being financed at full cost, if land is available as equity (Cunningham \& Fairchild, 2009).

Poultry production is a long term commitment for producers who choose to build houses and raise poultry (MacDonald, 2008). The typical loan for a poultry operation is for fifteen years for payback on the operation. "Poultry growers have experienced significant increased heating fuel costs. Increased energy costs combined with weak consumer spending produced negative returns for most broiler integrators." (Cunningham \& Fairchild, 2009,p.2) According to McDonald (2008), broiler operations with one or two houses provide additional family income but it is unlikely to be the primary source of employment

The lack of competition for companies can also affect a producer. Producers are generally limited as to the number of companies they have available to contract their poultry production within a given geographic location. A producer needs one company to contract with, but in some areas producers have the option of up to three (MacDonald, 2008).

The bankruptcy of a major local integrator and its recent sale (Aho, 2009) has increased the unrest of local producers and left producers wondering what this could mean to the local economy. Poultry production is important to not only the growers and those employed by the industry, but the overall economy of an area or region (Cunningham, 2009A).

The last major studies of the opinions of poultry producers were conducted in the late 1990's. Two of these studies have been well documented and published. The first conducted by Schrader and Wilson (2001) surveyed 
producers in ten states about their perceptions and satisfaction with raising poultry. The study also asked about debt loading and income on poultry operations. Another study conducted by Ilvento and Watson (1998) focused on producers on the Delmarva Peninsula and did not focus on income or debt loading of operations.

\section{Problem Statement}

The poultry industry in West Virginia and Virginia is a vital part to the rural local economies that depend on the jobs produced by these industries, as well as, the farm income that enters the local economy. The producers have not been given an opportunity for some time to tell an outside group how they feel about their chosen occupation and raising contract poultry in the current economy. This study will give producers that chance to improve producer relations in the poultry producing regions of Virginia and West Virginia. In order to improve the poultry industry in West Virginia and Virginia, the producers need an opportunity to express their opinions on how they feel about the poultry industry, their income and their company.

\section{Purpose of the Study}

The purpose of this study was to determine producers' attitudes about raising poultry under contract. Contract producers were given the opportunity to provide feedback on their companies' communication, payment structure and grower relations. 


\section{Objectives of Study}

The focus of this project was to determine satisfaction of contract poultry producers in West Virginia and Virginia. Producers raise birds under a flock to flock contract and through this study have been given the opportunity to voice their opinions about their choices and how it has affected their family income. The objectives of this study were:

1. Determine satisfaction of contract poultry producers compared to type of poultry raised.

2. Determine reasons why poultry producers began raising contact poultry and if it impacts their satisfaction.

3. Determine whether having an off farm income affects a producer's satisfaction with raising poultry.

4. Determine if producer opinions of their integrators, performance, and other factors affect production and does this impact producer satisfaction?

5. What are the impacts of debt load and income on poultry operations and does this impact producer satisfaction?

6. Do specific demographics impact producer satisfaction with raising contract poultry?

\section{Limitations of Study}

This study was limited to the accessible poultry producers whose contact information was provided by their integrator for this study. There are seven companies who contract poultry in West Virginia and Virginia, only one company was willing to share their grower contact lists. The lists comprised the names 
and addresses of producers from one complex in West Virginia and one complex in Virginia. 


\section{CHAPTER II}

\section{Review of Literature}

The poultry industry in the US is very diverse and located primarily in the southeast United States. The industry has seen many ups and downs and faces many challenges including the current economy, the instability of the two largest poultry companies in the United States, environmental issues and producer profitability (Industry Correspondence, 2009).

Broiler production is the leading agricultural commodity produced in Virginia and West Virginia. With an annual production rate of 88 million birds a year in West Virginia and 250 million birds produced in Virginia, it is the most valuable agricultural commodity produced in each state (National Agriculture Statistics Service, 2007). The broiler industry is divided into to two regions of Virginia, the Eastern Shore and the Shenandoah Valley. Rockingham County in Virginia is the number three broiler producing county in the United States. In West Virginia, the broiler industry is located in the Potomac Headwaters region.

There is one major integrator in West Virginia that produces broilers and four in Virginia. The companies are Pilgrim's Pride, Tyson Inc, George's Foods and Perdue Farms. Except for Perdue all three companies produce broilers in West Virginia and Virginia. Perdue does contract broiler breeder operations in West Virginia and Virginia. According to the Virginia Poultry Federation (2007) there are approximately 1100 poultry farms operating in Virginia and according to National Agricultural Statistics Service (2007) there are approximately 350 contract poultry farms operating in West Virginia. 
The poultry industry in this country started out by accident in Sussex County Delaware. Since that time, the industry has grown to producing over 9 billion broilers a year in the US (National Agriculture Statistics Service, 2007). According to Goodwin (2005) "the poultry industry represents the most vertically integrated sector of all US agriculture and food production (p. 339)." Through vertical integration, producers raise poultry under contract for a company until the birds reach a certain age. According to MacDonald (2008) and Cunningham (1997), producer contracts are typically paid on a competitive basis and require a long term commitment for producers involved in poultry production.

MacDonald (2008) explains:

Broiler production is organized in a distinctive manner. Most farms are linked to an integrator through a will production contract, under which the integrator provides chicks, will, veterinary services, and other inputs to the farmer, who grows the birds to market weight. Besides providing their own labor, farmers invest in specialized poultry housing (along with associated equipment), pay for any hired labor, and bear some or all the cost of utilities. Because broiler housing is specialized and long-lived, the decision to produce broilers is a long-term commitment, and most producers have worked with their integrator for at least 10 years.

Integrators usually own hatcheries, feed mills, slaughter plants, and further processing plants-that is, they may be vertically integrated into all stages except for broiler production, where they 
rely on networks of growers assembled through production contracts. Integrators also contract with, or own, primary breeder companies that develop poultry breeding stock, and they contract with other farm operations to produce broiler eggs for hatcheries. (p. 3-4)

Vertical integration reduces product costs through coordinating and professionally managing each production stage. This approach not only improves cost efficiency, but permits the production of more uniform birds in large volumes necessary to successfully compete in the market. In this system, the integrator is responsible for all processing facilities, processing labor and salaries, and marketing activities crucial to the success of the poultry business. Processing and marketing are very specialized and require considerable expertise and experience for success. For this system to work effectively, integrators and producers make significant contributions to the process and depend on each other (Cunningham, 2008).

When raising poultry under contract, producers have limited choices of who they can contract to raise poultry in their given geographic location. MacDonald (2008) states that, "Nearly a quarter (24.7\%) reported that only a single integrator served their area, while another 28.7 percent reported two and 21.7 percent reported three(p. 13)."

The lack of integrators for producers to choose from has become a topic in recent years when assessing producer satisfaction. In the last ten years, there have been three major studies of producer satisfaction with raising poultry under 
contract. In 2001, Goodwin examined poultry producer satisfaction. Schrader and Wilson (2001) surveyed producers in ten states about their perceptions and satisfaction with raising poultry. They also focused on income and debt loading on the poultry operations. In 1998, Ilvento and Watson conducted a study that focused on producers on the Delmarva Peninsula.

There are some similarities and differences in the study findings. Goodwin's (2001) survey of Arkansas poultry producers found that $78 \%$ of respondents agreed or strongly agreed they had a good relationship with their company representatives. Schrader and Wilson (2001) found that producers were more likely to have a good relationship with their service personnel than upper company management. Ilvanto and Watson (1998) found that $88.9 \%$ of growers believed they had a good relationship with their flock serviceperson, while only $52 \%$ believed that company management understood the concerns of producers.

In the three poultry producer surveys satisfaction of raising poultry was examined. Goodwin (2001) found that growers were generally satisfied with poultry production and optimistic about the future of the poultry industry in Arkansas. Ilvento and Watson (1998) found that overall most poultry growers were satisfied with their business as a poultry grower with $73 \%$ indicating satisfaction. Schrader and Wilson (2001) did not specifically ask if producers were satisfied, but $57 \%$ responded they earned about what they expected or more than they expected in income from their poultry operations. 
Studies conducted by Schrader and Wilson (2001) and Ilvanto and Watson (1998) evaluated producers income from farm and off farm sources. Schrader and Wilson (2001) found that $37 \%$ of the respondents had an off farm job and $45 \%$ of their spouses worked off the farm. While Ilvanto and Watson (1998) found that $14.4 \%$ of the producers raised poultry part time and worked mostly off the farm, while $25 \%$ of the producers indicated they raised poultry part time and concentrated on other farm operations. IIvanto and Watson (1998) also found that $47.2 \%$ of the respondent's spouses worked off the farm either full or part time. Schrader and Wilson (2001)studied income for the poultry operations. Sixty-six percent of the producers indicated they had an income of $\$ 0-\$ 29,999$ with $66 \%$ of the respondents also having a debt load of less than $\$ 199,999$ on their operations.

Fernandez-Cornejo, Mishra, Nehring, Hendricks, Southern, \& Gregory (2007) found that "farm level efficiency decreases as off farm activities increase" (pp 12-16). The study also found that smaller farm operations were more likely to participate in off farm employment and have a higher off farm income than large farm operations (Fernandez-Cornejo, et. al, 2007, pp. 12-16).

Current demographics, as reported by McDonald (2008) in the document The Economic Organization of US Broiler Production, states that most poultry operations are small with less than four houses. Forty-five percent of producers in the United States raise birds on a flock to flock contract and smaller operations tend to have older houses and farm operations are maintained by older producers. 


\section{Summary}

A review of literature indicates that poultry producers have not been asked about their satisfaction for quite some time. The last major studies on producer satisfaction were conduced approximately 10 years ago. There have been many changes in the poultry industry during the past 10 years. There has also been a significant change in the economics of the poultry industry with fluctuating fuel and feed prices which has created uncertainty and instability in the industry. USDA and other government entities, have maintained studies on the economics of raising poultry and the costs associated with contract poultry production. Producers in West Virginia and Virginia have not been given an opportunity to express their concerns and satisfaction with raising poultry under contract. 


\section{CHAPTER III}

\section{Methodology}

\section{Problem Statement}

The poultry industry in West Virginia and Virginia is a vital part to the rural local economies that depend on the jobs produced by these industries, as well as, the farm income that enters the local economy. The producers have not been given an opportunity for some time to tell an outside group how they feel about their chosen occupation and raising contract poultry in the current economy. This study will give producers that chance to improve producer relations in the poultry producing regions of Virginia and West Virginia. In order to improve the poultry industry in West Virginia and Virginia, the producers need an opportunity to express their opinions on how they feel about the poultry industry, their income and their company.

\section{Purpose of Study}

The purpose of this study was to provide producers an opportunity to express their attitudes about raising poultry under contract. Contract producers were given the opportunity to provide feedback on their companies' communication, payment structure and grower relations.

\section{Objectives of Study}

The focus of this project was to determine satisfaction of contract poultry producers in West Virginia and Virginia. Producers raise birds under a flock to flock contract and through this study have been given the opportunity to voice their opinions about their choices and how it has affected their family income. 
The objectives of this study were:

1. Determine satisfaction of contract poultry producers compared to type of poultry raised.

2. Determine reasons why poultry producers began raising contact poultry and if it impacts their satisfaction.

3. Determine whether having an off farm income affects a producer's satisfaction with raising poultry.

4. Determine if producer opinions of their integrators, performance, and other factors affect production and does this impact producer satisfaction?

5. What are the impacts of debt load and income on poultry operations and does this impact producer satisfaction?

6. Do specific demographics impact producer satisfaction with raising contract poultry?

\section{Research Design}

A descriptive research design using a mailed questionnaire was used to determine the satisfaction of poultry producers in Virginia and West Virginia. According to Ary, Jacobs, Razavieh, and Sorensen (2006), survey research allows the researcher to measure the attitudes and opinions of a group toward some issue and to summarize characteristics of the group.

\section{Population}

There were approximately 1500 commercial poultry farms in Virginia and West Virginia (National Agriculture Statistics Service, 2007). These operations produce broilers, broiler breeders, turkeys, pullets, turkey breeders and primary 
breeders under contract. The companies that produce poultry in these states are Pilgrim's Pride, Tyson, Perdue Farms Inc, Cargill, Georges Inc, and the Virginia Poultry Growers Cooperative.

The target population for this study was all producers who raise poultry under contract in Virginia and West Virginia. A request was sent to the poultry companies asking them to provide their producer names and contact information for this study.

Privacy of contract producers is important to poultry companies and all integrators except one denied the request for their producers contact information. This company provided their contact list which totaled 383 producers (multiple contacts for single producers were removed from the data set). A census of all producers was conducted. A total of 160 producers responded to the survey for a response rate of $42 \%$.

\section{Instrumentation}

A single survey was sent to contract poultry producers in West Virginia and Virginia. The survey consisted of Likert - type questions with six responses available. The responses included completely agree, agree, somewhat agree, somewhat disagree, disagree and completely disagree. Neutral was not included so that respondents had to give an opinion on each topic. This type of question was chosen because it is the way to determine attitudes on a subject (Ary et al., 2006). In addition to the Likert type questions, the instrument including single response questions and demographic type questions. 


\section{Reliability}

The reliability of the instrument was determined using the final data set from all respondents. The questionnaire responses were used to determine internal consistency using an unequal Spearman Brown. Reliability was found to be exemplary with a Spearman Brown of .98 (Robinson, Shaver, \& Wrightsman, 1991). The instrument was determined to be reliable in nature.

\section{Validity}

The survey was developed using two previous surveys and was presented to a panel of experts to establish content and face validity. The panel of experts consisted of teacher educators in Agricultural and Extension Education and poultry research in Extension and Nutritional Sciences at West Virginia University, Each individual on the panel had extensive teaching, research and experience in extension at the university. The panel of experts concluded the instrument had content and face validity.

Through the use of a mailed questionnaire, the researcher was able to reach the accessible population regardless location. There are five errors which

exist with survey research that need to be controlled. To avoid frame error, only the official lists provided by the poultry integrator were used. A census of all names was conducted to avoid sample error. Selection error was avoided by going through the list of producer names and addresses and making sure that each producer only appeared once on the official lists.

Measurement error was controlled by making sure the instrument was valid and reliable. To address non-response error, early and late respondents 
were compared on the factors of age, off-farm job, expectations of income involved in poultry production and state of residence. A significant difference was found between state of residence and early and late respondents. Therefore, generalizations from this study will be limited to those who responded.

\section{Data Collection Procedures}

With the support of the poultry integrator, a letter was left at each farm by their service person notifying them of the upcoming survey that was going to be sent to them in the mail in approximately two weeks. Dillman's (2008) Tailored Design Method was used to communicate with the participants for this study to maximize the response rate. The initial letter to the producers contained a cover letter explained the research study, a questionnaire, a self-addressed stamped envelope and a return card for a gift card drawing for those who participated.

Approximately two weeks after the initial notification, a second mailing was sent to producers containing a cover letter explaining the research study, a questionnaire, a self-addressed stamped envelope and a return card for entry into the gift card drawing for those who participated in the study. After the second mailing, the poultry integrator again left notification with the producers asking them to please return the surveys if they had not yet done so.

\section{Analysis of Data}

The data collected from each respondent were compiled into an Excel spreadsheet and were analyzed using the SPSS data analysis software. Descriptive analyses were performed on the data and the appropriate methods of reporting each type of data were used. 
To account for non response error a Chi-square of independence analysis between four variables was calculated. The four variables were early and late responders compared to age, off farm job, the respondents expected income with raising poultry, and state of residence. "Research has shown that nonrespondents are often similar to late respondents," (Ary, et.al, 2006, p. 439). State of residence variable showed a significant difference. Due to the difference between state of residence, generalizations were limited to the participants who responded.

\section{Use of Findings}

The findings from this study will be used to draw conclusions about the attitudes and opinions of poultry producers in West Virginia and Virginia, The information gathered will be shared with the integrators and producers who participated in the study. Extension personnel, poultry educators, poultry organizations and others in the industry will be provided the information for educational and outreach purposes. 


\section{CHAPTER IV}

\section{Findings}

\section{Problem Statement}

The poultry industry in West Virginia and Virginia is a vital part to the rural local economies that depend on the jobs produced by these industries, as well as, the farm income that enters the local economy. The producers have not been given an opportunity for some time to tell an outside group how they feel about their chosen occupation and raising contract poultry in the current economy. This study will give producers that chance to improve producer relations in the poultry producing regions of Virginia and West Virginia. In order to improve the poultry industry in West Virginia and Virginia, the producers need an opportunity to express their opinions on how they feel about the poultry industry, their income and their company.

\section{Purpose of Study}

The purpose of this study was to provide producers an opportunity to express their attitudes about raising poultry under contract. Contract producers were given the opportunity to provide feedback on their companies' communication, payment structure and grower relations.

\section{Objectives of Study}

The focus of this project was to determine satisfaction of contract poultry producers in West Virginia and Virginia. Producers raise birds under a flock to flock contract and through this study have been given the opportunity to voice their opinions about their choices and how it has affected their family income. 
The objectives of this study were:

1. Determine satisfaction of contract poultry producers compared to type of poultry raised.

2. Determine reasons why poultry producers began raising contact poultry and if it impacts their satisfaction.

3. Determine whether having an off farm income affects a producer's satisfaction with raising poultry.

4. Determine if producer opinions of their integrators, performance, and other factors affect production and does this impact producer satisfaction?

5. What are the impacts of debt load and income on poultry operations and does this impact producer satisfaction?

6. Do specific demographics impact producer satisfaction with raising contract poultry?

\section{Demographics}

The mailed questionnaire was sent to 383 poultry producers in West Virginia and Virginia. Of the 380 surveys sent, 160 were returned for a response rate of $42 \%$. One hundred seven (66.9\%) were considered early respondents and 53 (33. 1\%) were late respondents (see Table 1).

Table 1

Early Versus Late Respondents

\begin{tabular}{lcc}
\hline & $\mathrm{N}$ & $\%$ \\
\hline Early & 107 & 66.9 \\
Late & 53 & 33.1 \\
\hline
\end{tabular}


When asked if this operation was currently engaged in poultry production, $158(98.8 \%)$ responded yes, one (.6\%) respondent indicated no, they were never engaged in poultry production, and one (.6\%) response was missing (see Table 2).

Table 2

Poultry Operation Involved in Production

\begin{tabular}{lrc}
\hline & $N$ & $\%$ \\
\hline Yes & 158 & 98.8 \\
No (never engaged) & 1 & .6 \\
Missing & 1 & .6 \\
\hline
\end{tabular}

A majority of the respondents were broiler producers, 112 (70.9\%) indicated they raised broilers under contract. Thirty-four (21.5\%) respondents raised broiler breeders and $12(7.6 \%)$ raised pullets (see Table 3).

Table 3

Type Poultry Produced

\begin{tabular}{lrc}
\hline & N & $\%$ \\
\hline Broilers & 112 & 70.9 \\
Broiler Breeders & 34 & 21.5 \\
Pullets & 12 & 7.6 \\
\hline
\end{tabular}

The last major expansion of the poultry industry was in 1996 . The mean number of years that respondents had been raising poultry was 19.95 with a standard deviation of 10.59 (see Table 4). 
Table 4

Years Raising Contract Poultry

M

Years raising poultry under
19.95
SD

10.59

When asked what they were doing prior to raising poultry under contract, $63(39.8 \%)$ producers indicated they were operating a farm while $68(42.8 \%)$ were working off the farm and 11 (6.9\%) were working as a homemaker. Twelve (7.5\%) were completing their high school education and 10 (6.3\%) were completing their college education (see Table 5).

Table 5

Employment Prior to Raising Poultry

\begin{tabular}{lcc}
\hline & $\mathrm{N}$ & $\%$ \\
\hline Operating a farm & 63 & 39.6 \\
Working off the farm & 68 & 42.8 \\
Homemaker & 11 & 6.9 \\
Completing high school education & 12 & 7.5 \\
Completing college education & 10 & 6.3 \\
\hline
\end{tabular}

When asked to indicate the importance of various reasons for entering the poultry profession, $103(66.9 \%)$ responded it was very important to make more money, 49 (31.8\%) stated that making more money was somewhat important and two (1.3\%) responded it was not at all important. Seventy (46.4\%) stated a very important factor was to have something extra to live on in their retirement, 
while $53(35.1 \%)$ responded it was somewhat important. Twenty-eight (18.5\%) responded it was not at all important (see Table 6). Ten (7.1\%) responded that the fact that it was the easiest way for them to get financing was very important in their decision to enter into poultry production. Thirty-six (25.5\%) responded it was somewhat important and 95 (67.4\%) responded it was not at all important. Eighty-six (57.0\%) stated to provide more financial security was a very important reason for them to enter the contract poultry business, 53 (35.1\%) responded it was somewhat important and $12(7.9 \%)$ respondents responded it was not all important (see Table 6).

Diversifying an existing farm operation was very important to 64 (43.5\%) of the respondents. It was that somewhat important to 44 (29.9\%) and not at all important to $39(26.5 \%)$ of the respondents (see Table 6). It was very important, to $45(30.4 \%)$ of respondents who responded the poultry production has been in their family. Thirty-seven (25.0\%) responded it was somewhat important and 66 (44.6\%) responded that it was not at all important poultry production had been in their family (see Table 6). 
Table 6

Reasons for Entering Poultry Profession

\begin{tabular}{|c|c|c|c|c|c|c|}
\hline & \multicolumn{2}{|c|}{$\begin{array}{l}\text { Not at All } \\
\text { Important }\end{array}$} & \multicolumn{2}{|c|}{$\begin{array}{l}\text { Somewhat } \\
\text { Important }\end{array}$} & \multicolumn{2}{|c|}{ Very Important } \\
\hline & $\mathrm{N}$ & $\%$ & $\mathrm{~N}$ & $\%$ & $\mathrm{~N}$ & $\%$ \\
\hline Make more money & 2 & 1.3 & 49 & 31.8 & 103 & 66.9 \\
\hline Have extra for retirement & 28 & 18.5 & 53 & 35.1 & 70 & 46.4 \\
\hline $\begin{array}{l}\text { Easiest way to get } \\
\text { financing }\end{array}$ & 95 & 67.4 & 36 & 25.5 & 10 & 7.1 \\
\hline $\begin{array}{l}\text { Provide more financial } \\
\text { security }\end{array}$ & 12 & 7.9 & 53 & 35.1 & 86 & 57.0 \\
\hline $\begin{array}{l}\text { Diversify existing farm } \\
\text { operation }\end{array}$ & 39 & 26.5 & 44 & 29.9 & 64 & 43.5 \\
\hline $\begin{array}{l}\text { Poultry production has } \\
\text { been in family }\end{array}$ & 66 & 44.6 & 37 & 25.0 & 45 & 30.4 \\
\hline $\begin{array}{l}\text { Enable family to work } \\
\text { together }\end{array}$ & 41 & 28.3 & 66 & 45.5 & 38 & 26.2 \\
\hline Be my own boss & 28 & 18.3 & 48 & 31.4 & 77 & 50.3 \\
\hline Other & 1 & 9.1 & 1 & 9.1 & 9 & 81.8 \\
\hline
\end{tabular}

When producers were asked about where they got information about the income they expected to earn raising poultry $62(43.1 \%)$ responded the integrator was very important in providing information (see Table 7). Fifty-six (38.9\%) responded that their integrator was somewhat important and 26 (18.1\%) responded it was not at all important. A family member's information on income expected to raise from earning poultry was very important to $53(36.3 \%)$ of the respondents, it was somewhat important to 45 (30.8\%) and not at all important to 
$48(32.9 \%)$ of respondents. Information provided by other poultry growers was very important to $68(46.3 \%)$ respondents, somewhat important to $62(42.2 \%)$ and not at all important to $17(11.6 \%)$ respondents.

Information from Farm Credit was very important to 32 (22.9\%) respondents, it was somewhat important to $41(29.3 \%)$ and not at all important to $67(47.9 \%)$ of survey respondents (see Table 7$)$. Ten (7.4\%) responded that the Farm Service Agency was very important in providing information about income they expected to earn from raising poultry, $35(25.7 \%)$ consider this information somewhat important and 91 (66.9\%) responded this information source was not all important. Nine (6.7\%) of the respondents indicated the Extension service was a very important source for information about income expected to raise earning poultry, 29 (21.5\%) felt it was somewhat important and $97(71.9 \%)$ of the respondents indicated it was not at all important. When looking for information about income expected to earn while raising poultry $11(8.1 \%)$ indicated a poultry association was very important, 35 (25.9\%) felt that it was somewhat important and $89(65.9 \%)$ responded it was not at all important (see Table 7). 
Table 7

Where Received Information About Income Expectations from Raising Poultry

\begin{tabular}{lrrrrrr}
\hline & \multicolumn{2}{c}{$\begin{array}{c}\text { Not at All } \\
\text { Important }\end{array}$} & \multicolumn{2}{c}{$\begin{array}{c}\text { Somewhat } \\
\text { Important }\end{array}$} & \multicolumn{2}{c}{ Very Important } \\
& N & $\%$ & $\mathrm{~N}$ & $\%$ & $\mathrm{~N}$ & $\%$ \\
\hline Integrator & 26 & 18.1 & 56 & 38.9 & 62 & 43.1 \\
Family Member & 48 & 32.9 & 45 & 30.8 & 53 & 36.3 \\
Other poultry growers & 17 & 11.6 & 62 & 42.2 & 68 & 46.3 \\
Farm Credit Services & 67 & 47.9 & 41 & 29.3 & 32 & 22.9 \\
Farm Service Agency & 91 & 66.9 & 35 & 25.7 & 10 & 7.4 \\
Extension Service & 97 & 71.9 & 29 & 21.5 & 9 & 6.7 \\
Poultry Association & 89 & 65.9 & 35 & 25.9 & 11 & 8.1 \\
Other Farm & & & & & & .0 \\
Organizations & 54 & 94.7 & 3 & 5.3 & 0 & 28.6 \\
Other & 15 & 71.4 & 0 & .0 & 6 & 5.9 \\
Other & 16 & 94.1 & 0 & .0 & 1 & \\
\hline
\end{tabular}

Producers were asked if they currently worked off the farm, 48 (30.2\%) responded yes and 111 (69.8\%) responded no. When asked if the farm operation raised crops or other livestock in addition to raising poultry, 114 (72.6\%) responded yes, while $43(27.4 \%)$ responded no. When asked if the producer was married or living with a partner, 130 (85.4\%) responded yes and 23 (14.6\%) responded no. And when asked if your spouse or partner worked off the farm, 73 (54.1\%) responded yes and 62 (45.9\%) responded no (see Table 8). 
Table 8

Farm Income

\begin{tabular}{lrrrr}
\hline & \multicolumn{3}{c}{ No } & \multicolumn{2}{c}{ Yes } \\
\cline { 2 - 5 } & $\mathrm{N}$ & $\%$ & $\mathrm{~N}$ & $\%$ \\
\hline Currently have an off farm job & 111 & 69.8 & 48 & 30.2 \\
$\begin{array}{l}\text { Raise crops or livestock in addition to raising } \\
\text { poultry }\end{array}$ & 43 & 27.4 & 114 & 72.6 \\
Married or living with a partner & 23 & 14.6 & 135 & 85.4 \\
Spouse or partner work off the farm & 62 & 45.9 & 73 & 54.1 \\
\hline
\end{tabular}

Producers who responded they had off farm employment were then asked to indicate if they were employed full time or part time. Thirty-six (92.3\%) respondents worked off the farm full time and three (7.7\%) were employed parttime (see Table 9).

Table 9

Off Farm Job Full Time or Part Time

\begin{tabular}{lcc}
\hline & $\mathrm{N}$ & $\%$ \\
\hline Full Time & 36 & 92.3 \\
Part Time & 3 & 7.7 \\
\hline
\end{tabular}

Producers were asked, do you have health insurance for your family. Sixty-six (43.7\%) stated yes that insurance was provided by an off farm job. Thirty-seven (24.5\%) respondents responded yes they had an individual policy and $16(10.6 \%)$ responded they had a group policy. Thirty-two (21.2\%) of the 
respondents stated they did not have any kind of health insurance for their family (see Table 10).

Table 10

Family Health Insurance

\begin{tabular}{lcc}
\hline & $\mathrm{N}$ & $\%$ \\
\hline Yes, provided by off farm job & 66 & 43.7 \\
Yes, individual policy & 37 & 24.5 \\
Yes, group policy & 16 & 10.6 \\
No & 32 & 21.2 \\
\hline
\end{tabular}

Producers were asked to indicate the number of paid employees on their poultry operation. Survey respondents indicated an average of 1.5 paid employees $(S D=2.63)$. The number of part-time paid employees was an average of $1.07(\mathrm{SD}=1.18)$, and the number of full-time paid employees averaged 1.21 $(\mathrm{SD}=2.27)($ see Table 11).

Table 11

Paid Farm Employees

\begin{tabular}{lll}
\hline & M & SD \\
\hline Total number of paid employees & 1.54 & 2.63 \\
Number of part time paid employees & 1.07 & 1.18 \\
Number of full time paid employees & 1.21 & 2.27 \\
\hline
\end{tabular}

Respondents were asked to list the average number of hours per day that they work on their poultry operation during several stages of the operation. The producers indicated the first two weeks after they receive a new flock of birds 
they worked a mean of 4.6 hours per day $(S D=3.85)$. During the rest of the production cycle, producers indicated that they worked an averag of 4.24 hours per day $(S D=3.78)$. When preparing for each new flock, they worked a mean of 8.74 hours $(S D=9.13)$. During each major cleanout, producers worked a mean of 9.80 hours $(S D=11.87)$ (see Table 12).

Other household members worked a mean of 2.83 hours per day $(\mathrm{SD}=$ 3.45) in the first two weeks after the farm received birds and with a mean of 2.84 hours per day $(S D=2.65)$ during the rest of the production cycle. Other household members worked an average of 4.96 hours per day $(S D=5.56)$ in preparation for each new flock with a mean of $5.71(S D=7.41)$ during each major cleanout (see Table 12).

Producers indicated hired employees worked an average of 5.29 $(S D=10.96)$ hours each day in the first two weeks after receiving a new flock of birds. During the rest of the production cycle, hired employees worked a mean of 7.05 hours per day $(S D=27.56)$. When preparing for a new flock, these employees worked a mean of 7.37 hours per day $(S D=12.02)$. At each major clean out, the paid employees also worked a mean of 8.03 hours per day (SD=11.66) (see Table 12). 
Table 12

Hours Worked on Poultry Operation

\begin{tabular}{lccccccc}
\hline & \multicolumn{3}{c}{ Hours You Work } & \multicolumn{3}{c}{$\begin{array}{l}\text { Other } \\
\text { Household } \\
\text { Hours }\end{array}$} & Hired Hours \\
& M & SD & M & SD & M & SD \\
First two weeks with birds & 4.60 & 3.85 & 2.83 & 3.45 & 5.29 & 10.96 \\
Rest of the production period & 4.24 & 3.78 & 2.84 & 2.65 & 7.05 & 27.56 \\
Preparation for new flock & 8.74 & 9.13 & 4.96 & 5.56 & 7.37 & 12.02 \\
During each major cleanout & 9.80 & 11.87 & 5.71 & 7.41 & 8.03 & 11.66 \\
\hline
\end{tabular}

Producers were next asked about their contract, their settlement and payment for their work done raising contract birds. These responses were ranked by the producer using a Likert scale. Respondents overall were in agreement, with the statement, "my company provides me with helpful information about flock management". Twenty-five (15.8\%) completely agreed with the statement, $69(43.7 \%)$ respondents agreed with the statement and 47 (29.7\%) respondents somewhat agreed with the statement. Eight (5.1\%) respondents somewhat disagreed, while five (3.2\%) disagreed and four (2.5\%) completely disagreed with the statement (see Table 13).

Twenty-nine (18.5\%) respondents completely agreed with the statement, "I feel free to complain to my company if I have a problem." Forty-seven (29.9\%) agreed with the statement and 40 (25.5\% somewhat agreed with the statement. Fifteen (9.6\%) somewhat disagreed with the statement and $13(8.3 \%)$ of 
respondents either disagreed are completely disagreed with the statement (see Table 13).

The statement, "my service person is a good judge of the quality of my work," was completely agreed upon by 38 (24.2\%) respondents, 76 (48.4\%) agreed with the statement and 28 respondents (17.8\%) somewhat agreed with that statement. Six (3.8\%) respondents somewhat disagreed with the statement, while two (1.3\%) disagreed and seven (4.5\%) respondents completely disagreed with the statement.

Most producers also agreed with the statement, "I have made a real effort to read and understand my contract." Forty-two (26.9\%) completely agreed with the statement, $75(48.1 \%)$ agreed and 28 (17.9\%) somewhat agreed with the statement. Five (3.2\%) respondents somewhat disagreed or disagreed with the statement, and one (.6\%) respondent completely disagreed with the statement (see Table 13).

Twenty-nine (18.8\%) of the respondents completely agreed with the statement, "I understand the terms of my contract," 60 (39.0\%) agreed and 44 (28.6\%) somewhat agreed. Of the respondents who disagreed with the statement, 11 (7.1\%) somewhat disagreed, seven (4.5\%) disagreed and three (1.9\%) completely disagreed. Twenty-one (13.6\%) completely agreed with the statement, "I understand the calculations on my settlement sheet." Fifty-three individuals (34.4\%) agreed with the statement and 36 (23.4\%) somewhat agreed. Of the producers who disagreed with the statement, 17 (11.0\%) somewhat 
disagreed, 16 (10.4\%) disagreed and 11 (7.1\%) completely disagreed (see Table 13).

The statement, "the settlement method provides me a good incentive to work hard," was completely agreed upon by $15(9.7 \%)$ of respondents, 36 (23.4\%) agreed with the statement. Thirty-five respondents (22.7\%) somewhat agreed with the statement. Twenty-three (14.9\%) of the producers somewhat disagreed with the statement, $25(16.2 \%)$ disagreed and 20 of the respondents (13.0\%) completely disagreed with the statement (see Table 13).

Fifty-eight (38.7\%) of the respondents completely agree with the statement, "my pay depends more on the quality of chicks supplied by the company than on the quality of my work." Twenty-nine (19.3\%) of the respondents agreed with the statement and 47 (31.3\%) somewhat agreed. Seven $(4.7 \%)$ of the respondents somewhat disagreed with the statement, six (4.0\%) disagreed and three (2.0\%) of the respondents completely disagreed. Most producers were in agreement with the statement, "my pay depends more on the quality of the feeds supplied by my company than on the quality of my work." Fifty-three (34.9\%) of respondents completely agreed, 34 (22.4\%) agreed with the statement and $46(30.3 \%)$ somewhat agreed. Of respondents who disagreed, 12 (7.9\%) somewhat disagreed, five (3.3\%) disagreed and two (1.3\%) of the respondents completely disagreed (see Table 13).

Twenty-four (15.3\%) of the respondents strongly agreed with the statement, "the time my family and I spend caring for the poultry is more than my company led me to expect." Twenty-seven (17.2\%) agreed with the statement 
and $44(28.0 \%)$ of the respondents somewhat agreed. Twenty-eight (17.8\%) of the respondents either disagreed or somewhat disagreed and six (3.8\%) completely disagreed with the statement (see Table 13).

Thirteen (8.4\%) respondents completely agreed with the statement, "the improvements to my house as suggested by my company have made me better off." Twenty-nine (18.7\%) of the respondents agreed with the statement and 68 (38.7\%) somewhat agreed with the statement. Twenty-five (16.1\%) of the respondents somewhat disagreed with the statement, 16 (10.3\%) disagreed and $12(7.7 \%)$ producers completely disagreed (see Table 13).

The statement, "my company strongly suggests that new equipment should be purchased from particular vendors," was strongly agreed upon by 14 (9.0\%) of the respondents, $22(14.2 \%)$ agreed with the statement and $35(22.6 \%)$ somewhat agreed. Twenty-three (14.8\%) somewhat disagreed, 41 (26.5\%) disagreed and 20 (12.9\%) completely disagreed with the statement.

Twenty-two (15.7\%) of respondents completely agree with the statement, "my contract will not be renewed unless I follow my company's recommendations about building new houses." Thirty-two individuals (22.9\%) agreed with the statement and $20(14.3 \%)$ somewhat agreed with the statement. Of respondents who disagreed, 18 (12.9\%) somewhat disagreed, 29 (20.7\%) disagreed and 19 (13.6\%) completely disagreed (see Table 13).

Twenty-six (17.7\%) of the respondents strongly agreed with the statement, "my contract will be renewed unless I follow my company's recommendations about making major improvements to my old houses." Thirty-nine (26.5\%) 
agreed and 29 (19.7\%) somewhat agreed with the statement. Of the respondents who were in disagreement, 23 (15.6\%) somewhat disagreed, 22 (15.0\%) disagreed and eight (5.4\%) of the respondents completely disagreed with the statement (see Table 13).

Most producers agreed with the statement, "poultry growers are also company employees should not be included in the same grow out group as others." Fifty-eight (37.7\%) completely agreed with the statement, while 30 (19.5\%) producers agreed and $25(16.2 \%)$ producers somewhat agreed with the statement. Nine (5.8\%) of the respondents somewhat disagreed with the statement, while 20 (13.0\%) disagreed and 12 (7.8\%) completely disagreed.

Twenty-eight (17.7\%) of the respondents strongly agreed with the statement, "getting into poultry growing has been a good decision for me." Fiftytwo (32.9\%) of the respondents agreed with the statement and $40(25.3 \%)$ somewhat agreed. Ten (6.3\%) of respondents somewhat disagreed with the statement, while 13 (8.2\%) disagreed and 15 (9.5\%) completely disagreed.

Nine (5.8\%) of the respondents completely agreed with the statement, "I would encourage others to become poultry growers." Fifteen (9.7\%) agreed with the statement and $50(32.5 \%)$ somewhat agreed. Twenty (13.0\%) producers somewhat disagreed with the statement, and $22(14.3 \%)$ of the respondents disagreed and $38(24.7 \%)$ of the respondents completely disagreed with the statement (see Table 13). 
Table 13

Producer Level of Agreement on Company Operations

\begin{tabular}{|c|c|c|c|c|c|c|c|c|c|c|c|c|}
\hline & \multicolumn{2}{|c|}{$\begin{array}{l}\text { Completely } \\
\text { Disagree }\end{array}$} & \multicolumn{2}{|c|}{ Disagree } & \multicolumn{2}{|c|}{$\begin{array}{l}\text { Somewhat } \\
\text { Disagree }\end{array}$} & \multicolumn{2}{|c|}{$\begin{array}{l}\text { Somewhat } \\
\text { Agree }\end{array}$} & \multicolumn{2}{|c|}{ Agree } & \multicolumn{2}{|c|}{$\begin{array}{l}\text { Completely } \\
\text { Agree }\end{array}$} \\
\hline & $\mathrm{N}$ & $\%$ & $N$ & $\%$ & $\mathrm{~N}$ & $\%$ & $\mathrm{~N}$ & $\%$ & $\mathrm{~N}$ & $\%$ & $\mathrm{~N}$ & $\%$ \\
\hline $\begin{array}{l}\text { Company provides helpful } \\
\text { information about flock management }\end{array}$ & 4 & 2.5 & 5 & 3.2 & 8 & 5.1 & 47 & 29.7 & 69 & 43.7 & 25 & 15.8 \\
\hline $\begin{array}{l}\text { I feel free to complain to my } \\
\text { company if I have a problem }\end{array}$ & 13 & 8.3 & 13 & 8.3 & 15 & 9.6 & 40 & 25.5 & 47 & 29.9 & 29 & 18.5 \\
\hline $\begin{array}{l}\text { My service person is a good judge of } \\
\text { the quality of my work }\end{array}$ & 7 & 4.5 & 2 & 1.3 & 6 & 3.8 & 28 & 17.8 & 76 & 48.4 & 38 & 24.2 \\
\hline $\begin{array}{l}\text { I have made a real effort to read and } \\
\text { understand my contract }\end{array}$ & 1 & .6 & 5 & 3.2 & 5 & 3.2 & 28 & 17.9 & 75 & 48.1 & 42 & 26.9 \\
\hline $\begin{array}{l}\text { I understand the terms of my } \\
\text { contract }\end{array}$ & 3 & 1.9 & 7 & 4.5 & 11 & 7.1 & 44 & 28.6 & 60 & 39.0 & 29 & 18.8 \\
\hline $\begin{array}{l}\text { I understand the calculations on my } \\
\text { settlement sheet }\end{array}$ & 11 & 7.1 & 16 & 10.4 & 17 & 11.0 & 36 & 23.4 & 53 & 34.4 & 21 & 13.6 \\
\hline $\begin{array}{l}\text { The settlement method provides me } \\
\text { a good incentive to work hard }\end{array}$ & 20 & 13.0 & 25 & 16.2 & 23 & 14.9 & 35 & 22.7 & 36 & 23.4 & 15 & 9.7 \\
\hline
\end{tabular}


Table 13 (continued)

Producer Level of Agreement on Company Operations

\begin{tabular}{|c|c|c|c|c|c|c|c|c|c|c|c|c|}
\hline & \multicolumn{2}{|c|}{$\begin{array}{l}\text { Completely } \\
\text { Disagree }\end{array}$} & \multicolumn{2}{|c|}{ Disagree } & \multicolumn{2}{|c|}{$\begin{array}{l}\text { Somewhat } \\
\text { Disagree }\end{array}$} & \multicolumn{2}{|c|}{$\begin{array}{l}\text { Somewhat } \\
\text { Agree }\end{array}$} & \multicolumn{2}{|c|}{ Agree } & \multicolumn{2}{|c|}{$\begin{array}{c}\text { Completely } \\
\text { Agree }\end{array}$} \\
\hline & $N$ & $\%$ & $N$ & $\%$ & $\mathrm{~N}$ & $\%$ & $\mathrm{~N}$ & $\%$ & $\mathrm{~N}$ & $\%$ & $\mathrm{~N}$ & $\%$ \\
\hline $\begin{array}{l}\text { My pay depends more on the quality } \\
\text { of chicks supplied by the company } \\
\text { than on the quality of my work }\end{array}$ & 3 & 2.0 & 6 & 4.0 & 7 & 4.7 & 47 & 31.3 & 29 & 19.3 & 58 & 38.7 \\
\hline $\begin{array}{l}\text { My pay depends more on the quality } \\
\text { of the feed supplied by the company } \\
\text { than on the quality of my work }\end{array}$ & 2 & 1.3 & 5 & 3.3 & 12 & 7.9 & 46 & 30.3 & 34 & 22.4 & 53 & 34.9 \\
\hline $\begin{array}{l}\text { Time spent by my family and I caring } \\
\text { for the poultry is more than company } \\
\text { led me to expect }\end{array}$ & 6 & 3.8 & 28 & 17.8 & 28 & 17.8 & 44 & 28.0 & 27 & 17.2 & 24 & 15.3 \\
\hline $\begin{array}{l}\text { Improvements to houses suggested } \\
\text { by company have made me better } \\
\text { off }\end{array}$ & 12 & 7.7 & 16 & 10.3 & 25 & 16.1 & 60 & 38.7 & 29 & 18.7 & 13 & 8.4 \\
\hline $\begin{array}{l}\text { Company strongly suggests that new } \\
\text { equipment be purchased from } \\
\text { particular vendors }\end{array}$ & 20 & 12.9 & 41 & 26.5 & 23 & 14.8 & 35 & 22.6 & 22 & 14.2 & 14 & 9.0 \\
\hline
\end{tabular}


Table 13 (continued)

Producer Level of Agreement on Company Operations

\begin{tabular}{|c|c|c|c|c|c|c|c|c|c|c|c|c|}
\hline & \multicolumn{2}{|c|}{$\begin{array}{l}\text { Completely } \\
\text { Disagree }\end{array}$} & \multicolumn{2}{|c|}{ Disagree } & \multicolumn{2}{|c|}{$\begin{array}{l}\text { Somewhat } \\
\text { Disagree }\end{array}$} & \multicolumn{2}{|c|}{$\begin{array}{l}\text { Somewhat } \\
\text { Agree }\end{array}$} & \multicolumn{2}{|c|}{ Agree } & \multicolumn{2}{|c|}{$\begin{array}{l}\text { Completely } \\
\text { Agree }\end{array}$} \\
\hline & $\mathrm{N}$ & $\%$ & $\mathrm{~N}$ & $\%$ & $\mathrm{~N}$ & $\%$ & $\mathrm{~N}$ & $\%$ & $\mathrm{~N}$ & $\%$ & $\mathrm{~N}$ & $\%$ \\
\hline $\begin{array}{l}\text { Contract will not be renewed unless I } \\
\text { follow company's recommendations } \\
\text { about building new houses }\end{array}$ & 19 & 13.6 & 29 & 20.7 & 18 & 12.9 & 20 & 14.3 & 32 & 22.9 & 22 & 15.7 \\
\hline $\begin{array}{l}\text { Contract will not be renewed unless I } \\
\text { follow company's recommendations } \\
\text { about making major improvements to } \\
\text { old houses }\end{array}$ & 8 & 5.4 & 22 & 15.0 & 23 & 15.6 & 29 & 19.7 & 39 & 26.5 & 26 & 17.7 \\
\hline $\begin{array}{l}\text { Poultry growers who are also } \\
\text { company employees should not be } \\
\text { included in the same grow-out group } \\
\text { as others }\end{array}$ & 12 & 7.8 & 20 & 13.0 & 9 & 5.8 & 25 & 16.2 & 30 & 19.5 & 58 & 37.7 \\
\hline $\begin{array}{l}\text { Getting into poultry growing has } \\
\text { been a good decision }\end{array}$ & 15 & 9.5 & 13 & 8.2 & 10 & 6.3 & 40 & 25.3 & 52 & 32.9 & 28 & 17.7 \\
\hline $\begin{array}{l}\text { I would encourage others to become } \\
\text { poultry growers }\end{array}$ & 38 & 24.7 & 22 & 14.3 & 20 & 13.0 & 50 & 32.5 & 15 & 9.7 & 9 & 5.8 \\
\hline
\end{tabular}


Using a Likert Scale, producers were asked to respond with their level of agreement about company operations and how they feel the company treats them as a producer. The statement, "company management responds helpfully to my complaints," saw eight (5.1\%) of the respondents completely agreed with that statement. Thirty-two (20.5\%) agreed with the statement and 62 (39.7\%) somewhat agreed. Of respondents who disagreed with the statement, 27 (17.3\%) somewhat disagreed, $11(7.1 \%)$ disagreed and 16 (10.3\%) completely disagreed with the statement (see Table 14).

Most respondents agreed with the statement, "my service person takes the time to help me understand and follow recommendations." Thirty-three (20.9\%) producers completely agreed, while 72 (45.6\%) agreed with the statement and 38 (24.1\%) of the respondents somewhat agreed. Four (2.5\%) somewhat disagreed with the statement, six (3.8\%) disagreed and five (3.2\%) respondents completely disagreed with the statement.

Most of the respondents were also in agreement with the statement, "my service person makes a written evaluation after visiting my farm." Fifty-five (34.8\%) completely agreed with the statement, while 88 (55.7\%) agreed and 11 (7.0\%) somewhat agreed. One respondent (.6\%) somewhat disagreed with the statement and three (1.9\%) respondents disagreed with the statement (see Table 14).

When asked about the statement, "my service person provides me with a hard copy of any written evaluation." Forty-seven (30.7\%) producers completely agreed with the statement, $80(52.3 \%)$ agreed and $15(9.8 \%)$ of the respondents 
somewhat agreed with the statement. Four (2.6\%) of the respondents somewhat disagreed with the statement their service person provides them with a hard copy of any written evaluation, six (3.9\%) disagreed and one (.7\%) completely disagreed with the statement.

Most respondents agreed with the statement, "my service person keeps promises made to me." Thirty-three (21.0\%) producers completely agreed with the statement, $66(42.0 \%)$ agreed and 41 (26.1\%) somewhat agreed with the statement, seven (4.5\%) of the respondents somewhat disagreed and five (3.2\%) selected disagree or completely disagree (see Table 14).

Respondents disagreed with the statement, "my service person is hard to contact between visits." Thirty-six individuals (23.1\%) completely disagreed, 54 (34.6\%) producers disagreed and $33(21.2 \%)$ somewhat disagreed with that statement. Five respondents (3.2\%) completely agreed with the statement that their service person is hard to contact between visits, nine (5.8\%) agreed and 19 $(12.2 \%)$ somewhat agreed with the statement.

Twenty-nine (19.2\%) of the respondents completely agreed with the statement, "I am left without birds long enough to hurt me financially." Twentyfour respondents (15.9\%) agreed with the statement and 29 (19.2\%) somewhat agreed. Seventeen (11.3\%) producers somewhat disagreed with the statement, while $43(28.5 \%)$ of the respondents disagreed and nine (6.0\%) completely disagreed with the statement (see Table 14).

Respondents were in agreement with the statement, "chicks are delivered to my farm when promised." Fifty producers (31.8\%) completely agreed, while 92 
(58.6\%) agreed and 12 (7.6\%) somewhat agreed with the statement. Only three respondents (1.9\%) disagreed with the statement (see Table14).

Five (3.3\%) of the respondents strongly agreed with the statement, "goodquality chicks are delivered to my farm." Thirty-four producers (22.2\%) agreed with the statement and 75 (49.0\%) somewhat agreed. Seventeen (11.1\%) of the respondents somewhat disagreed with the statement, while $16(10.5 \%)$ disagreed and six (3.9\%) of the respondents completely disagreed with the statement.

The statement, "the chick count I'm given is accurate," was completely agreed upon by $11(7.5 \%)$ of the respondents, 54 (37.0\%) agreed and 64 (43.8\%) somewhat agreed with the statement. Eight (5.5\%) of the respondents somewhat disagreed with the statement five (3.4\%) disagreed, and four (2.7\%) completely disagreed with the statement (see Table 14)

"Birds are weighed promptly once they get to the plant," was completely agreed upon by six (5.1\%) of the respondents, 45 (38.1\%) agreed and 46 (39.0\%) somewhat agreed with the statement. Seven (5.9\%) of the respondents somewhat disagreed with the statement while eight (6.8\%) disagreed and six (5.1\%) completely disagreed with the statement.

Most respondents agreed, "the catching crew does a good job." Sixteen producers (10.5\%) strongly agreed with the statement, 61 (39.9\%) agreed and 60 (39.2\%) somewhat agreed with the statement. Nine (5.9\%) of respondents somewhat disagreed with the statement while three (2.0\%) disagreed with the statement and four (2.6\%) is completely disagreed 
Five (3.4\%) of the respondents completely agreed with the statement, "my company provides them with good-quality feed." Forty producers (27.0\%) agreed and 65 (43.9\%) somewhat agreed. Eighteen (12.2\%) somewhat disagreed with 12 (8.1\%) disagreeing and eight (5.4\%) completely disagreeing (see Table 14).

Most respondents agreed with the statement, "feed is delivered to my farm as scheduled." Twenty-one individuals (13.9\%) completely agreed with the statement, while $80(53.0 \%)$ agreed and $43(28.5 \%)$ somewhat agreed with the statement. Four respondents (2.6\%) somewhat disagreed and three (2.0\%) completely disagreed with the statement.

Most respondents disagreed with the statement "I am charged for more feed that is delivered." Twenty producers (15.4\%) completely disagreed, while 40 (30.8\%) disagreed and 44 (33.8\%) somewhat disagreed with the statement. Two respondents (1.5\%) completely agreed with the statement while five (3.8\%) agreed and 19 (14.6\%) somewhat agreed with the statement.

Six (4.3\%) of the respondents strongly agreed with the statement, "feed is emptied from my bins and not credited to my account." Twelve (8.7\%) agreed and $13(9.4 \%)$ somewhat agreed with the statement. Most respondents disagreed with the statement with 33 (23.9\%) somewhat disagreed with the statement, 47 (34.1\%) disagreed with the statement and 27 (19.6\%) completely disagreeing with the statement (see Table 14). 
Table 14

Producer Level of Agreement with Statements Related to Company and Service Person

\begin{tabular}{|c|c|c|c|c|c|c|c|c|c|c|c|c|}
\hline & \multicolumn{2}{|c|}{$\begin{array}{l}\text { Completely } \\
\text { Disagree }\end{array}$} & \multicolumn{2}{|c|}{ Disagree } & \multicolumn{2}{|c|}{$\begin{array}{l}\text { Somewhat } \\
\text { Disagree }\end{array}$} & \multicolumn{2}{|c|}{$\begin{array}{l}\text { Somewhat } \\
\text { Agree }\end{array}$} & \multicolumn{2}{|c|}{ Agree } & \multicolumn{2}{|c|}{$\begin{array}{l}\text { Completely } \\
\text { Agree }\end{array}$} \\
\hline & $\mathrm{N}$ & $\%$ & $\mathrm{~N}$ & $\%$ & $\mathrm{~N}$ & $\%$ & $\mathrm{~N}$ & $\%$ & $\mathrm{~N}$ & $\%$ & $\mathrm{~N}$ & $\%$ \\
\hline $\begin{array}{l}\text { Company management responds } \\
\text { helpfully to my complaints }\end{array}$ & 16 & 10.3 & 11 & 7.1 & 27 & 17.3 & 62 & 39.7 & 32 & 20.5 & 8 & 5.1 \\
\hline $\begin{array}{l}\text { My service person takes time to help } \\
\text { me understand and follow }\end{array}$ & & & & & & & & & & & & \\
\hline recommendations & 5 & 3.2 & 6 & 3.8 & 4 & 2.5 & 38 & 24.1 & 72 & 45.6 & 33 & 20.9 \\
\hline $\begin{array}{l}\text { My service person makes a written } \\
\text { evaluation after visiting my farm }\end{array}$ & 0 & .0 & 3 & 1.9 & 1 & .6 & 11 & 7.0 & 88 & 55.7 & 55 & 34.8 \\
\hline $\begin{array}{l}\text { My service person provides me with } \\
\text { a hard copy of any written evaluation }\end{array}$ & 1 & .7 & 6 & 3.9 & 4 & 2.6 & 15 & 9.8 & 80 & 52.3 & 47 & 30.7 \\
\hline $\begin{array}{l}\text { My service person keeps the } \\
\text { promises made to me }\end{array}$ & 5 & 3.2 & 5 & 3.2 & 7 & 4.5 & 41 & 26.1 & 66 & 42.0 & 33 & 21.0 \\
\hline $\begin{array}{l}\text { My service person is hard to contact } \\
\text { between visits }\end{array}$ & 36 & 23.1 & 54 & 34.6 & 33 & 21.2 & 19 & 12.2 & 9 & 5.8 & 5 & 3.2 \\
\hline $\begin{array}{l}\text { I am left without birds long enough to } \\
\text { hurt me financially }\end{array}$ & 9 & 6.0 & 43 & 28.5 & 17 & 11.3 & 29 & 19.2 & 24 & 15.9 & 29 & 19.2 \\
\hline
\end{tabular}


Table 14 (continued)

Producer Level of Agreement with Statements Related to Company and Service Person

\begin{tabular}{|c|c|c|c|c|c|c|c|c|c|c|c|c|}
\hline & \multicolumn{2}{|c|}{$\begin{array}{l}\text { Completely } \\
\text { Disagree }\end{array}$} & \multicolumn{2}{|c|}{ Disagree } & \multicolumn{2}{|c|}{$\begin{array}{l}\text { Somewhat } \\
\text { Disagree }\end{array}$} & \multicolumn{2}{|c|}{$\begin{array}{l}\text { Somewhat } \\
\text { Agree }\end{array}$} & \multicolumn{2}{|c|}{ Agree } & \multicolumn{2}{|c|}{$\begin{array}{l}\text { Completely } \\
\text { Agree }\end{array}$} \\
\hline & $\mathrm{N}$ & $\%$ & $\mathrm{~N}$ & $\%$ & $\mathrm{~N}$ & $\%$ & $\mathrm{~N}$ & $\%$ & $\mathrm{~N}$ & $\%$ & $\mathrm{~N}$ & $\%$ \\
\hline $\begin{array}{l}\text { Chicks are delivered to my farm } \\
\text { when promised }\end{array}$ & 0 & .0 & 3 & 1.9 & 0 & .0 & 12 & 7.6 & 92 & 58.6 & 50 & 31.8 \\
\hline $\begin{array}{l}\text { Good quality chicks are delivered to } \\
\text { my farm }\end{array}$ & 6 & 3.9 & 16 & 10.5 & 17 & 11.1 & 75 & 49.0 & 34 & 22.2 & 5 & 3.3 \\
\hline $\begin{array}{l}\text { The chick count I am given is } \\
\text { accurate }\end{array}$ & 4 & 2.7 & 5 & 3.4 & 8 & 5.5 & 64 & 43.8 & 54 & 37.0 & 11 & 7.5 \\
\hline $\begin{array}{l}\text { Birds are weighed promptly once } \\
\text { they get to the plant }\end{array}$ & 6 & 5.1 & 8 & 6.8 & 7 & 5.9 & 46 & 39.0 & 45 & 38.1 & 6 & 5.1 \\
\hline The catching crew does a good job & 4 & 2.6 & 3 & 2.0 & 9 & 5.9 & 60 & 39.2 & 61 & 39.9 & 16 & 10.5 \\
\hline $\begin{array}{l}\text { My company provides me with good } \\
\text { quality feed }\end{array}$ & 8 & 5.4 & 12 & 8.1 & 18 & 12.2 & 65 & 43.9 & 40 & 27.0 & 5 & 3.4 \\
\hline $\begin{array}{l}\text { Feed is delivered to my farm as } \\
\text { scheduled }\end{array}$ & 3 & 2.0 & 0 & .0 & 4 & 2.6 & 43 & 28.5 & 80 & 53.0 & 21 & 13.9 \\
\hline $\begin{array}{l}\text { I am charged for more feed than is } \\
\text { delivered }\end{array}$ & 20 & 15.4 & 40 & 30.8 & 44 & 33.8 & 19 & 14.6 & 5 & 3.8 & 2 & 1.5 \\
\hline
\end{tabular}


Table 14 (continued)

Producer Level of Agreement with Statements Related to Company and Service Person

\begin{tabular}{|c|c|c|c|c|c|c|c|c|c|c|c|c|}
\hline & \multicolumn{2}{|c|}{$\begin{array}{c}\text { Completely } \\
\text { Disagree }\end{array}$} & \multicolumn{2}{|c|}{ Disagree } & \multicolumn{2}{|c|}{$\begin{array}{c}\text { Somewhat } \\
\text { Disagree }\end{array}$} & \multicolumn{2}{|c|}{$\begin{array}{l}\text { Somewhat } \\
\text { Agree }\end{array}$} & \multicolumn{2}{|c|}{ Agree } & \multicolumn{2}{|c|}{$\begin{array}{c}\text { Completely } \\
\text { Agree }\end{array}$} \\
\hline & $\mathrm{N}$ & $\%$ & $\mathrm{~N}$ & $\%$ & $\mathrm{~N}$ & $\%$ & $\mathrm{~N}$ & $\%$ & $\mathrm{~N}$ & $\%$ & $\mathrm{~N}$ & $\%$ \\
\hline $\begin{array}{l}\text { Feed is emptied from my bins and } \\
\text { not credited to my account }\end{array}$ & 27 & 19.6 & 47 & 34.1 & 33 & 23.9 & 13 & 9.4 & 12 & 8.7 & 6 & 4.3 \\
\hline $\begin{array}{l}\text { Growers who are company } \\
\text { employees are included in my grow- } \\
\text { out group }\end{array}$ & 15 & 12.1 & 22 & 17.7 & 16 & 12.9 & 22 & 17.7 & 35 & 28.2 & 14 & 11.3 \\
\hline
\end{tabular}


The statement, "growers who are company employees are included in my grow out group," was completely agreed upon by $14(11.3 \%)$ of the respondents to the survey. Thirty-five producers (28.2\%) agreed with the statement and 22 (17.7\%) somewhat agreed with the statement. Sixteen (12.9\%) somewhat disagreed with the statement, $22(17.7 \%)$ disagreed with the statement and 15 (12.1\%) completely disagreed (see Table 14).

Survey participants were asked to think back over the last three years and determine if the terms of their contracts have been changed to increase their net pay. Ninety-six (62.3\%) of the respondents indicated no. Forty-one (26.6\%) responded yes their contract terms had been changed to increase their net pay and 17 (11.0\%) did not know (see Table 15).

Table 15

Have the Terms of Your Contract Been Changed to Increase Net Pay

\begin{tabular}{lcc}
\hline & $N$ & $\%$ \\
\hline No & 96 & 62.3 \\
Yes & 41 & 26.6 \\
Don't Know & 17 & 11.0 \\
\hline
\end{tabular}

Producers were asked, based on the information you've received from the company when you're starting out, has your income from the poultry operation been more than you expected, about what you expected, or less than you expected. Eight (5.2\%) respondents indicated their income was more than expected, $73(47.1 \%)$ responded it was about what was expected and 74 $(47.7 \%)$ of the respondents indicated it was less than expected (see Table 16). 
Table 16

Income Expectations

\begin{tabular}{lcc}
\hline & $\mathrm{N}$ & $\%$ \\
\hline More than expected & 8 & 5.2 \\
About what I expected & 73 & 47.1 \\
Less than expected & 74 & 47.7 \\
\hline
\end{tabular}

The producers who responded their income was less than expected were asked, why has your income been less than expected. Twenty-one (13.2\%) of the respondents indicated it was because they have received fewer chicks than promised. Thirty (18.9\%) selected it was because more chicks have died than I had anticipated, 39 (24.5\%) stated their layout periods were too long and 33 (20.8\%) indicated they have been given poor quality feed or the wrong feed. I have been given poor quality chicks was selected by $48(30.2 \%)$ of respondents and nine $(5.7 \%)$ of the respondents indicated my birds have not received adequate veterinary care (see Table 17).

Twenty-one (13.2\%) of the respondents indicated their contract terms have changed and 73 (45.9\%) selected my operating costs have risen faster than expected. Thirty-one (19.5\%) respondents selected, the company required expensive improvements. This business has turned out to be more complicated than I thought was selected by $13(8.2 \%)$ respondents and 16 (10.1\%) selected they never seem to have enough time to do the work that needs to be done. Ten respondents (6.3\%) stated they have lost interest in growing poultry, while nine (5.7\%) chose other as an option (see Table 17). 
Table 17

Reasons for Lower Income Expectations

\begin{tabular}{lcc}
\hline & $\mathrm{N}$ & $\%$ \\
\hline Received fewer chicks than promised & 21 & 13.2 \\
More chicks have died than anticipated & 30 & 18.9 \\
Layout periods are too long & 39 & 24.5 \\
Given poor quality feed or the wrong feed & 33 & 20.8 \\
Given poor quality chicks & 48 & 30.2 \\
Birds have not received adequate veterinary care & 9 & 5.7 \\
Contract terms changed & 21 & 13.2 \\
Operating costs have risen faster than expected & 73 & 45.9 \\
Company required expensive improvements & 31 & 19.5 \\
Business is more complicated than I thought & 13 & 8.2 \\
Never seem to have enough time to do the work & 16 & 10.1 \\
needed & 10 & 6.3 \\
Lost interest in growing poultry & 9 & 5.7 \\
Other (please specify): & & \\
\hline
\end{tabular}

Producers were asked at the end of 2008, what was the total farm debt on your entire operation. Forty-one producers (27.7\%) indicated their debt load was under $\$ 49,999$. Twenty-eight (18.9\%) producers indicated their debt load was $\$ 50,000-\$ 99,000$ and 20 (13.5\%) respondents selected $\$ 100,000-\$ 199,999$. In the category of $\$ 200,000-\$ 299,999,11(7.4 \%)$ of the respondents made this selection and 22 (14.9\%) selected $\$ 300,000-\$ 499,999$. Ten (6.8\%) selected a total farm debt of $\$ 500,000-\$ 599,999$ on their operation and in the category of 
$\$ 600,000$ to $\$ 699,999$, four (2.7\%) respondents made this selection. Three (2.0\%) of the respondents selected a debt load of $\$ 700,000-\$ 799,999$ for their farm operation and two (1.4\%) of the respondents each selected $\$ 800,000$ $\$ 899,999$ and $\$ 900,000-\$ 999,999$ of debt on their farm operation. Five (3.4\%) of the respondents indicated the total farm debt on their operation was $\$ 1$ million or more (see Table 18).

Table 18

Total Farm Debt

\begin{tabular}{lcc}
\hline & $\mathrm{N}$ & $\%$ \\
\hline Under $\$ 49,999$ & 41 & 27.7 \\
$\$ 50,000-\$ 99,999$ & 28 & 18.9 \\
$\$ 100,000-\$ 199,999$ & 20 & 13.5 \\
$\$ 200,000-\$ 299,999$ & 11 & 7.4 \\
$\$ 300,000-\$ 499,999$ & 22 & 14.9 \\
$\$ 500,000-\$ 599,999$ & 10 & 6.8 \\
$\$ 600,000-\$ 699,999$ & 4 & 2.7 \\
$\$ 700,000-\$ 799,999$ & 3 & 2.0 \\
$\$ 800,000-\$ 899,999$ & 2 & 1.4 \\
$\$ 900,000-\$ 999,999$ & 2 & 1.4 \\
$\$ 1,000,000$ or more & 5 & 3.4 \\
\hline
\end{tabular}

Producers were asked to indicate the percentage of farm debt that is owed on the poultry operation. Fifty-three (35.3\%) of the respondents indicated less than $25 \%$ of their farm debt is owed on the farm operation, 26 (17.3) of the respondents indicated a debt load of $25 \%$ to $49 \%$ and 14 (9.3\%) selected $50 \%$ to 
$74 \%$. Fifty-five (36.7\%) of the producers indicated that $75 \%$ or more of farm debt was owed on the poultry operation and two (1.3\%) did not know (see Table 19). Table 19

Percent of Farm Debt Owed on the Poultry Operation

\begin{tabular}{lcc}
\hline & N & $\%$ \\
\hline Less than $25 \%$ & 53 & 35.3 \\
$25 \%$ to $49 \%$ & 26 & 17.3 \\
$50 \%$ to $74 \%$ & 14 & 9.3 \\
$75 \%$ or more & 55 & 36.7 \\
Don't Know & 2 & 1.3 \\
\hline
\end{tabular}

Producers were also asked to indicate the net cash flow from their poultry production last year. Net cash flow meaning poultry income left over after paying poultry related to expenses such as poultry house mortgage payments, insurance, repairs, utilities and disposal of litter. Twenty-eight (18.7\%) of the respondents indicated they lost money on their poultry operation. Forty-two $(28 \%)$ of the producers indicated their income was between zero dollars and $\$ 14,999$ last year. Thirty-four (22.7\%) of the respondents indicated their income was between $\$ 15,000$ and $\$ 29,999$ last year and 32 (21.3\%) selected between $\$ 30,000$ and $\$ 44,999$. Six (4.0\%) producers selected income levels of $\$ 45,000$ and $\$ 59,999$, two (1.3\%) producers selected $\$ 75,000-\$ 89,999$. Three (2.0\%) producers each indicated their income was $\$ 60,000-74,999$ or over $\$ 90,000$ last year (see Table 20). 
Table 20

Net Cash Flow from Poultry Operation 2008

\begin{tabular}{lcc}
\hline & $\mathrm{N}$ & $\%$ \\
\hline Lost money & 28 & 18.7 \\
$\$ 0-\$ 14,999$ & 42 & 28.0 \\
$\$ 15,000-\$ 29,999$ & 34 & 22.7 \\
$\$ 30,000-\$ 44,999$ & 32 & 21.3 \\
$\$ 45,000-\$ 59,999$ & 6 & 4.0 \\
$\$ 60,000-\$ 74,999$ & 3 & 2.0 \\
$\$ 75,000-\$ 89,999$ & 2 & 1.3 \\
Over $\$ 90,000$ & 3 & 2.0 \\
\hline
\end{tabular}

Producers were asked to indicate if they produce crops or livestock other than poultry on the farm operation that accounted for more than $50 \%$ of their total gross farm income. Of the producers who responded, $122(79.2 \%)$ indicated no and $32(20.8 \%)$ of the respondents replied yes (see Table 21).

Table 21

Produce Crops or Livestock Other than Poultry Income

\begin{tabular}{lrc}
\hline & $N$ & $\%$ \\
\hline No & 122 & 79.2 \\
Yes & 32 & 20.8 \\
\hline
\end{tabular}

Producers were asked to indicate what percentage of the total family income last year was from the poultry operation. Total family income meant income contributed by all members of your household from other farm 
enterprises, all farm enterprises, off farm jobs, rental income and the like. Forty (26.5\%) producers stated that less than $25 \%$ of income was from the poultry operation and $42(27.8 \%)$ of the respondents indicated it was 25 to $49 \%$. Twenty-seven (17.9\%) of the producers stated that their total family income was 50 to $74 \%$ and $42(27.8 \%)$ responded total family income was more than $75 \%$ (see Table 22).

Table 22

Percentage of Farm Income from Poultry in 2008

\begin{tabular}{lll}
\hline & $\mathrm{N}$ & $\%$ \\
\hline Less than $25 \%$ & 40 & 26.5 \\
$25 \%$ to $49 \%$ & 42 & 27.8 \\
$50 \%$ to $74 \%$ & 27 & 17.9 \\
$75 \%$ or more & 42 & 27.8 \\
\hline
\end{tabular}

Producers were asked to indicate "how many times over the past 10 flocks has the operation been ranked better than average in your settlement group." Thirteen producers (8.7\%) indicated they did not know and $136(91.3 \%)$ indicated they had ranked better than average in their settlement group (see Table 23). Producers who stated they ranked better than average had ranked better on an average of 5.59 times with a standard deviation of 3.73 (see Table 24). 
Table 23

Number of Times Over the Past Ten Flocks Producer was Average or Better

\begin{tabular}{lcc}
\hline & $\mathrm{N}$ & $\%$ \\
\hline Don't Know & 13 & 8.7 \\
Yes & 136 & 91.3 \\
\hline
\end{tabular}

Table 24

Average Number of Times Producer Settled Better than Average

\begin{tabular}{lcc}
\hline & $M$ & SD \\
\hline Number of times & 5.59 & 3.73 \\
\hline
\end{tabular}

Producers were asked to indicate if they belonged to any farm organizations. Fifty-seven (35.8\%) were members of the West Virginia Poultry Association and 71 (44.7\%) were members of the Farm Bureau. Membership in the Virginia poultry Federation was held by $21(13.2 \%)$ respondents and 18 (11.3\%) were members of the Contract Poultry Growers Association of the Virginias. Two (1.3\%) indicated they belonged to other farm organizations (see Table 25).

Producers were asked to rank on a Likert scale their agreement or disagreement with the following statements. Twelve (7.6\%) of the respondents completely agreed with the statement, "I am satisfied with my business as a poultry grower." Forty-three producers (27.4\%) agreed and 61 (38.9\%) somewhat agreed with the statement. Fourteen (8.9\%) somewhat disagreed, while 17 (10.8\%) disagreed with the statement and 10 (6.4\%) completely disagreed. 
Table 25

Producers Membership in Farm Organizations

\begin{tabular}{lcc}
\hline & $\mathrm{N}$ & $\%$ \\
\hline West Virginia Poultry Association & 57 & 35.8 \\
Farm Bureau & 71 & 44.7 \\
Virginia Poultry Federation & 21 & 13.2 \\
Contract Poultry Growers' Association of Virginia's & 18 & 11.3 \\
Grange & 0 & .0 \\
Other & 2 & 1.3 \\
\hline
\end{tabular}

Twelve (7.7\%) completely agreed with the statement, "I am satisfied with my relationship with my present company. Forty-six producers (29.5\%) agreed and $57(36.5 \%)$ somewhat agreed. Fourteen (9.0\%) of the respondents somewhat disagreed with the statement, 12 (7.7\%) disagreed and 15 (9.6\%) completely disagreed with that statement (see Table 26).

Six (3.9\%) of the producers completely agreed with the statement, "I am satisfied with the income I receive from our poultry operation." Twenty-six (16.9\%) of the respondents agreed with the statement and $43(27.9 \%)$ somewhat agreed. Thirty (19.5\%) producers somewhat disagreed with the statement, while 26 (16.9\%) disagreed and 23 (14.9\%) completely disagreed.

The producers were in agreement with the statement "I am optimistic about the future of the poultry industry." Ten (7.1\%) completely agreed with the statement, 35 (24.8\%) agreed and 51 (36.2\%) somewhat agreed. Six 
respondents (4.3\%) completely disagreed with the statement, $15(10.6 \%)$ disagreed and 24 (17.0\%) somewhat disagreed.

When asked to indicate their level of agreement with the statement, "the poultry industry needs more government regulation," three (2.0\%) of the respondents completely agreed with the statement, five (3.3\%) agreed and 10 $(6.7 \%)$ of respondents somewhat agreed. A majority of the respondents disagreed with the statement "the poultry industry needs more government regulation," with 13 (8.7\%) somewhat disagreeing, 55 (36.7\%) disagreed and 64 (42.7\%) completely disagreed (see Table 26 ).

One $(.7 \%)$ of the respondents completely agreed with the statement, "I would recommend the poultry growing business to somewhat who is interested." Twenty-eight (18.4\%) agreed with the statement and 40 (26.3\%) somewhat agreed. A majority of the respondents disagreed with this statement with 24 (15.8\%) somewhat disagreeing, 28 (18.4\%) disagreeing and 31 (20.4\%) completely disagreed (see Table 26). 
Table 26

Producer Satisfaction toward Poultry Business

\begin{tabular}{|c|c|c|c|c|c|c|c|c|c|c|c|c|}
\hline & \multicolumn{2}{|c|}{$\begin{array}{l}\text { Completely } \\
\text { Disagree }\end{array}$} & \multicolumn{2}{|c|}{ Disagree } & \multicolumn{2}{|c|}{$\begin{array}{l}\text { Somewhat } \\
\text { Disagree }\end{array}$} & \multicolumn{2}{|c|}{$\begin{array}{l}\text { Somewhat } \\
\text { Agree }\end{array}$} & \multicolumn{2}{|c|}{ Agree } & \multicolumn{2}{|c|}{$\begin{array}{l}\text { Completely } \\
\text { Agree }\end{array}$} \\
\hline & $N$ & $\%$ & $\mathrm{~N}$ & $\%$ & $N$ & $\%$ & $\mathrm{~N}$ & $\%$ & $\mathrm{~N}$ & $\%$ & $\mathrm{~N}$ & $\%$ \\
\hline $\begin{array}{l}\text { Satisfied with business as a } \\
\text { poultry grower }\end{array}$ & 10 & 6.4 & 17 & 10.8 & 14 & 8.9 & 61 & 38.9 & 43 & 27.4 & 12 & 7.6 \\
\hline $\begin{array}{l}\text { Satisfied with relationship with } \\
\text { present company }\end{array}$ & 15 & 9.6 & 12 & 7.7 & 14 & 9.0 & 57 & 36.5 & 46 & 29.5 & 12 & 7.7 \\
\hline $\begin{array}{l}\text { Satisfied with the income } \\
\text { received from poultry operation }\end{array}$ & 23 & 14.9 & 26 & 16.9 & 30 & 19.5 & 43 & 27.9 & 26 & 16.9 & 6 & 3.9 \\
\hline $\begin{array}{l}\text { Optimistic about the future of the } \\
\text { poultry industry }\end{array}$ & 6 & 4.3 & 15 & 10.6 & 24 & 17.0 & 51 & 36.2 & 35 & 24.8 & 10 & 7.1 \\
\hline $\begin{array}{l}\text { Poultry industry needs more } \\
\text { government regulation }\end{array}$ & 64 & 42.7 & 55 & 36.7 & 13 & 8.7 & 10 & 6.7 & 5 & 3.3 & 3 & 2.0 \\
\hline $\begin{array}{l}\text { Would recommend the poultry } \\
\text { growing business to somewhat } \\
\text { who is interested }\end{array}$ & 31 & 20.4 & 28 & 18.4 & 24 & 15.8 & 40 & 26.3 & 28 & 18.4 & 1 & .7 \\
\hline
\end{tabular}


Survey respondents were asked to rank their level of agreement with the following statements using a Likert Scale. Twenty-one (13.3\%) respondents strongly agreed with the statement, "I can speak freely with representatives of my present company," 57 (36.1\%) agreed and 41 (25.9\%) somewhat agreed with the statement. Six (3.8\%) completely disagreed with the statement, 17 (10.8\%) disagreed and 16 (10.1\%) somewhat disagreed.

Six (3.9\%) of the respondents completely agreed with the statement, "company management understands the concerns of growers," 28 (18.1\%) agreed and 50 (32.3\%) somewhat agreed with the statement. Thirty-two (20.6\%) somewhat disagreed with the statement, while $19(12.3 \%)$ of the respondents disagreed and 20 (12.9\%) completely disagreed (see Table 27).

Six (3.9\%) of the respondents completely agreed with the statement, "if I have a question I can get a prompt response from my company." Forty-four (28.4\%) each agreed or somewhat agreed with the statement. Thirty-four $(21.9 \%)$ of the respondents somewhat disagreed with the statement, $16(10.3 \%)$ disagreed and 11 (7.1\%) completely disagreed.

When indicating their level of agreement, 17 (10.8\%) completely agreed and $66(41.8 \%)$ agreed with the statement, "I get the support I need when there is a problem with my flock." Forty-four (27.8\%) somewhat agreed. Thirteen (8.2\%) of all respondents somewhat disagreed with the statement, 11 (7.0\%) disagreed and 67 (4.4\%) completely disagreed with the statement.

Fourteen (9.0\%) of the producers completely agreed, with the statement, "my company provides information I need to know." Forty-eight (30.8\%) of the 
respondents agreed and $58(37.2 \%)$ somewhat agreed. Three (1.9\%) of the respondents completely disagreed with the statement while 17 (10.9\%) somewhat disagreed and 16 (10.3\%) disagreed (see Table 27).

Nine (5.8\%) of the respondents completely agreed or completely disagreed with the statement, "when new technology is introduced, I get adequate information from my poultry company with which to make decisions." Thirty-eight producers (24.5\%) agreed and 55 (35.5\%) somewhat agreed with the statement. Twenty (12.9\%) of the producers somewhat disagreed with the statement and 24 (15.5\%) disagreed (see Table 27).

When asked if "communication between growers and companies is adequate," $10(6.4 \%)$ of the respondents completely agreed with the statement, $33(21.2 \%)$ agreed and $46(29.5 \%)$ somewhat agreed with the statement.

Twenty-six (16.7\%) of the respondents somewhat disagreed with the statement, 27 (17.3\%) disagreed and 14 (9.0\%) completely disagreed.

Seven (4.6\%) of the respondents completely agreed with the statement, "my company is concerned with helping me increase my profits from my poultry operation." Twenty-four producers (15.7\%) agreed or disagreed and 40 (26.1\%) somewhat agreed or somewhat disagreed with the statement. Eighteen (11.8\%) of the respondents completely disagreed with the statement.

Ten (6.5\%) of the respondents completely agreed with the statement, "I consider myself a full and equal business partner with my company," 24 (15.5\%) agreed and 39 (25.2\%) somewhat agreed. Twenty-seven (17.4\%) somewhat 
disagreed with the statement, $33(21.3 \%)$ disagreed and $22(14.2 \%)$ completely disagreed.

Seventeen (11.3\%) of all respondents completely agreed with the statement "there should be a special company program for growers who have fallen below average with emphasis on problem identification and resolution." Fifty-seven (38.0\%) respondents somewhat agreed or agreed with the statement, $9(6.0 \%)$ somewhat disagreed, eight (5.3\%) disagreed and two (1.3\%) completely disagreed.

Eighteen (11.6\%) of the respondents completely agreed with the statement, "educational programs are needed to help producers better manage their operation." Thirty-eight (24.5\%) agreed and 64 (41.3\%) somewhat agreed. Five (3.2\%) of the respondents completely disagreed with the statement, while $12(7.7 \%)$ disagreed and 18 (11.6\%) somewhat disagreed.

Twenty-two (14.3\%) of the producers completely agreed with the statement, "I would attend educational programs on new technologies if it would improve my business." Sixty-nine producers (44.8\%) agreed and 43 (27.9\%) somewhat agreed with the statement. Nine (5.8\%) of the respondents somewhat disagreed or disagreed with the statement and two (1.3\%) completely disagreed with the statement. 
Table 27

Producer Attitudes toward Their Integrator

\begin{tabular}{|c|c|c|c|c|c|c|c|c|c|c|c|c|}
\hline & \multicolumn{2}{|c|}{$\begin{array}{l}\text { Completely } \\
\text { Disagree }\end{array}$} & \multicolumn{2}{|c|}{ Disagree } & \multicolumn{2}{|c|}{$\begin{array}{l}\text { Somewhat } \\
\text { Disagree }\end{array}$} & \multicolumn{2}{|c|}{$\begin{array}{l}\text { Somewhat } \\
\text { Agree }\end{array}$} & \multicolumn{2}{|c|}{ Agree } & \multicolumn{2}{|c|}{$\begin{array}{l}\text { Completely } \\
\text { Agree }\end{array}$} \\
\hline & $\mathrm{N}$ & $\%$ & $\mathrm{~N}$ & $\%$ & $N$ & $\%$ & $N$ & $\%$ & $\mathrm{~N}$ & $\%$ & $\mathrm{~N}$ & $\%$ \\
\hline $\begin{array}{l}\text { I can speak freely with } \\
\text { representatives of my } \\
\text { present company }\end{array}$ & 6 & 3.8 & 17 & 10.8 & 16 & 10.1 & 41 & 25.9 & 57 & 36.1 & 21 & 13.3 \\
\hline $\begin{array}{l}\text { Company management } \\
\text { understands the concerns of } \\
\text { growers }\end{array}$ & 20 & 12.9 & 19 & 12.3 & 32 & 20.6 & 50 & 32.3 & 28 & 18.1 & 6 & 3.9 \\
\hline $\begin{array}{l}\text { If I have a question, I can } \\
\text { get a prompt response from } \\
\text { my company }\end{array}$ & 11 & 7.1 & 16 & 10.3 & 34 & 21.9 & 44 & 28.4 & 44 & 28.4 & 6 & 3.9 \\
\hline $\begin{array}{l}\text { I get the support I need } \\
\text { when there is a problem } \\
\text { with my flock }\end{array}$ & 7 & 4.4 & 11 & 7.0 & 13 & 8.2 & 44 & 27.8 & 66 & 41.8 & 17 & 10.8 \\
\hline $\begin{array}{l}\text { My company provides } \\
\text { information I need to know }\end{array}$ & 3 & 1.9 & 16 & 10.3 & 17 & 10.9 & 58 & 37.2 & 48 & 30.8 & 14 & 9.0 \\
\hline
\end{tabular}


Table 27 (continued)

Producer Attitudes toward Their Integrator

\begin{tabular}{|c|c|c|c|c|c|c|c|c|c|c|c|c|}
\hline & \multicolumn{2}{|c|}{$\begin{array}{c}\text { Completely } \\
\text { Disagree }\end{array}$} & \multicolumn{2}{|c|}{ Disagree } & \multicolumn{2}{|c|}{$\begin{array}{l}\text { Somewhat } \\
\text { Disagree }\end{array}$} & \multicolumn{2}{|c|}{$\begin{array}{l}\text { Somewhat } \\
\text { Agree }\end{array}$} & \multicolumn{2}{|c|}{ Agree } & \multicolumn{2}{|c|}{$\begin{array}{c}\text { Completely } \\
\text { Agree }\end{array}$} \\
\hline & $\mathrm{N}$ & $\%$ & $\mathrm{~N}$ & $\%$ & $\mathrm{~N}$ & $\%$ & $\mathrm{~N}$ & $\%$ & $\mathrm{~N}$ & $\%$ & $\mathrm{~N}$ & $\%$ \\
\hline $\begin{array}{l}\text { When new technology is } \\
\text { introduced, I get adequate } \\
\text { information from my poultry } \\
\text { company with which to } \\
\text { make decisions }\end{array}$ & 9 & 5.8 & 24 & 15.5 & 20 & 12.9 & 55 & 35.5 & 38 & 24.5 & 9 & 5.8 \\
\hline $\begin{array}{l}\text { Communication between } \\
\text { growers and companies is } \\
\text { adequate }\end{array}$ & 14 & 9.0 & 27 & 17.3 & 26 & 16.7 & 46 & 29.5 & 33 & 21.2 & 10 & 6.4 \\
\hline $\begin{array}{l}\text { My company is concerned } \\
\text { with helping me increase my } \\
\text { profit from my poultry } \\
\text { operation }\end{array}$ & 18 & 11.8 & 24 & 15.7 & 40 & 26.1 & 40 & 26.1 & 24 & 15.7 & 7 & 4.6 \\
\hline $\begin{array}{l}\text { I consider myself a full and } \\
\text { equal business partner with } \\
\text { my company }\end{array}$ & 22 & 14.2 & 33 & 21.3 & 27 & 17.4 & 39 & 25.2 & 24 & 15.5 & 10 & 6.5 \\
\hline
\end{tabular}


Table 27 (continued)

Producer Attitudes toward Their Integrator

\begin{tabular}{|c|c|c|c|c|c|c|c|c|c|c|c|c|}
\hline & \multicolumn{2}{|c|}{$\begin{array}{l}\text { Completely } \\
\text { Disagree }\end{array}$} & \multicolumn{2}{|c|}{ Disagree } & \multicolumn{2}{|c|}{$\begin{array}{l}\text { Somewhat } \\
\text { Disagree }\end{array}$} & \multicolumn{2}{|c|}{$\begin{array}{l}\text { Somewhat } \\
\text { Agree }\end{array}$} & \multicolumn{2}{|c|}{ Agree } & \multicolumn{2}{|c|}{$\begin{array}{c}\text { Completely } \\
\text { Agree }\end{array}$} \\
\hline & $\mathrm{N}$ & $\%$ & $\mathrm{~N}$ & $\%$ & $\mathrm{~N}$ & $\%$ & $\mathrm{~N}$ & $\%$ & $\mathrm{~N}$ & $\%$ & $\mathrm{~N}$ & $\%$ \\
\hline $\begin{array}{l}\text { There should be a special } \\
\text { company program for } \\
\text { growers who have fallen } \\
\text { below average with } \\
\text { emphasis on problem } \\
\text { identification and resolution }\end{array}$ & 2 & 1.3 & 8 & 5.3 & 9 & 6.0 & 57 & 38.0 & 57 & 38.0 & 17 & 11.3 \\
\hline $\begin{array}{l}\text { Educational programs are } \\
\text { needed to help producers } \\
\text { better manage their } \\
\text { operation }\end{array}$ & 5 & 3.2 & 12 & 7.7 & 18 & 11.6 & 64 & 41.3 & 38 & 24.5 & 18 & 11.6 \\
\hline $\begin{array}{l}\text { I would attend educational } \\
\text { programs on new } \\
\text { technologies if it would } \\
\text { improve my business }\end{array}$ & 2 & 1.3 & 9 & 5.8 & 9 & 5.8 & 43 & 27.9 & 69 & 44.8 & 22 & 14.3 \\
\hline $\begin{array}{l}\text { I would attend training on } \\
\text { management techniques if it } \\
\text { would improve my business }\end{array}$ & 2 & 1.3 & 8 & 5.2 & 7 & 4.6 & 49 & 32.0 & 63 & 41.2 & 24 & 15.7 \\
\hline
\end{tabular}


Producers responded to the statement, "I would attend training on management techniques if it would improve my business," with 24 producers (15.7\%) completely agreeing with the statement. Sixty-three producers $(41.2 \%)$ agreed and 49 (32.0\%) somewhat agreeing with the statement. Seven (4.6\%) of the respondents somewhat disagreed with the statement, eight (5.2\%) disagreed and two (1.3\%) completely disagreed (see Table 27).

\section{Farm Demographics}

Producers were asked to give demographic information on their houses that are under contract with their poultry integrator. The mean number of houses under contract was 2.99 with a standard deviation of 1.69 . The mean age of the respondent's oldest house was 23.34 years with a standard deviation of 8.93. The mean age of the youngest house was 16.71 years with a standard deviation of 7.23. The number of houses on the farm using tunnel ventilation had a mean of 1.14 with a standard deviation of 1.50 and houses under negative pressure had a mean of 2.52 with a standard deviation of 2.1. The mean maximum farm capacity and birds per flock was $68,081.70$ with a standard deviation of 48,191.33 (see Table 28).

Survey respondents were asked to indicate their state of residence. One hundred two respondents (65.0\%) resided in the state of West Virginia and 55 (35.0\%) resided in Virginia (see Table 29). When asked to indicate their gender, $131(85.1 \%)$ of the respondents were male and 23 (14.9\%) were female (see Table 29) 
Table 28

Farm Demographics

M SD

How many houses are currently under

contract

$2.99 \quad 1.69$

What is the age of your oldest house

23.34

8.93

What is the age of your youngest house

16.71

7.23

How many houses use tunnel ventilation

1.14

1.50

How many houses use negative pressure

2.52

2.11

What is your maximum farm capacity in birds per flock

Table 29

State of Residence and Gender of Respondents

$\mathrm{N}$

State

West Virginia

Virginia

Gender

Male

Female
102

55

131

23
$\%$

65.0

35.0

When examining the age of respondents, one respondent (6\%) was between the ages of 20 and 25 years and three (1.9\%) respondents were in each of the following age categories: 25 and 30,30 and 35 and over 75 . Eight (5.2\%) respondents were in each of the following: 35 and 40 and 70 to 75 . Seventeen 
(11.0\%) indicated that their age was between 40 and 45, and $24(15.5 \%)$ of the respondents indicated their age range was 40 to 50 and 50 to 55. Thirty-two $(20.6 \%)$ of the respondents indicated they were in the age range of 55 to 60,19 (12.3\%) were in the 60 to 65 range and $13(8.4 \%)$ were the 65 to 70 range (see Table 30).

Table 30

Age of Respondents

\begin{tabular}{lcc}
\hline Years & $N$ & $\%$ \\
\hline $20-25$ & 1 & .6 \\
$25-30$ & 3 & 1.9 \\
$30-35$ & 3 & 1.9 \\
$35-40$ & 8 & 5.2 \\
$40-45$ & 17 & 11.0 \\
$45-50$ & 24 & 15.5 \\
$50-55$ & 24 & 15.5 \\
$55-60$ & 32 & 20.6 \\
$60-65$ & 19 & 12.3 \\
$65-70$ & 13 & 8.4 \\
$70-75$ & 8 & 5.2 \\
Over 75 & 3 & 1.9 \\
\hline
\end{tabular}

Survey respondents were asked to indicate the highest level of education completed. Sixteen (10.3) of the respondents indicated they had less than a high school education. Sixty-eight (43.9\%) indicated they were high school graduates, $20(12.9 \%)$ had attended trade or technical school and $22(14.2 \%)$ 
had some four-year college education. Twenty-one of the respondents (13.5\%) had a bachelors degree and eight (5.2\%) had a master's degree or higher (see Table 31).

Table 31

Level of Education

\begin{tabular}{lcc}
\hline & N & $\%$ \\
\hline Less than high school & 16 & 10.3 \\
High school graduate & 68 & 43.9 \\
Trade or technical school & 20 & 12.9 \\
Some four year college & 22 & 14.2 \\
Bachelor's degree & 21 & 13.5 \\
Masters degree or higher & 8 & 5.2 \\
\hline
\end{tabular}

A comparison of debt load and income was developed using crosstabs, of the respondents who indicated their farm debt load was under $\$ 49,999$, five (12.8\%) reported they lost money in 2008. Ten respondents (25.6\%) reported their income was $\$ 0-\$ 14,999$ and nine (23.1\%) reported their income level was $\$ 15,000-\$ 29,999$. Eleven respondents (28.2\%) who had a debt load under $\$ 49,999$ indicated they made $\$ 30,000$ - $\$ 44,999$ in 2008 . One respondent (2.6\%) in each category, indicated their farm income was, $\$ 45,000-\$ 59,000$, $\$ 60,000-\$ 74,999, \$ 75,000-\$ 89,999$ or over $\$ 90,000$ (see Table 32).

Of the survey respondents who indicated their farm debt load was $\$ 50,000-\$ 99,999$, four $(14.8 \%)$ producers reported their operation lost money in 2008, eight (29.6\%) reported they made between zero dollars and $\$ 14,999$ and 
five (18.5\%) indicated their income was between $\$ 15,000-\$ 29,999$ or $\$ 30,000$ $\$ 44,999$. Two respondents (7.4\%) each indicated their income level for 2008 was $\$ 45,000.03 \$ 59,999$ or $\$ 60,000-\$ 74,999$ and one respondent (3.7\%) responded their income was over $\$ 90,000$.

Seven respondents (36.8\%) indicated they had farm income of $\$ 0$ $\$ 14,999$ or $\$ 15,000-\$ 29,999$ with a debt load of $\$ 100,000-\$ 199,999$, four (21.1\%) had an income between $\$ 30,000-\$ 44,999$ and one (5.3\%) had a farm income of over $\$ 90,000$. Of the respondents who had a farm debt load of between $\$ 200,000$ and $\$ 299,999$, two respondents (18.2\%) each indicated they lost money, or had an income of $\$ 15,000-\$ 29,999$ or $\$ 30,000-\$ 44,999$. Four (36.4\%) producers indicated an income level of zero dollars to $\$ 14,999$ in one (9.1\%) producer responded they had an income of $\$ 45,000-\$ 59,999$ (see Table 32).

The survey respondents who indicated their debt load was $\$ 300,000$ $\$ 499,999$, one respondent (4.5\%) reported an income of $\$ 75,000-\$ 89,999$, six (27.3\%) had an income of $\$ 0-\$ 14,999$ or $\$ 30,000-\$ 44,999$. Four $(18.2 \%)$ indicated they lost money and five respondents (22.7\%) stated their income was $\$ 15,000-\$ 29,999$. Respondents with a debt load of $\$ 500,000-\$ 599,999$, had four (44.4\%) producers indicate they lost money in 2008 , one (11.1\%) each indicated they made between zero dollars and $\$ 14,999, \$ 30,000-\$ 44,999$ or $\$ 45,000$ $\$ 59,999$. Two (22.2\%) indicated their income in 2008 was $\$ 15,000-\$ 29,999$.

Farms who indicated a debt load of $\$ 600,000-\$ 699,999$ in 2008 had one (25.0\%) respondent each who indicated that operation lost money in 2008 ,or had 
an income of $\$ 45,000-\$ 59,999$ and two $(50 \%)$ indicated their income level was zero dollars to $\$ 14,999$. One respondent (33.3\%) each responded that in 2008 , their farm operation lost money, had an income of $\$ 15,000-\$ 29,999$ or $\$ 30,000$ $\$ 44,999$ and had a farm debt load of $\$ 700,000-\$ 799,999$. Of the farm operations with a debt load of $\$ 800,000-\$ 899,999$ or $\$ 900,000-\$ 999,999$; two (100\%) respondents indicated their farm income was $\$ 0-\$ 14,999$ in 2008 . Of the respondents who indicated that farm debt was $\$ 1$ million or more, two (40\%) responded the farm operation either lost money or had an income of $\$ 30,000$ $\$ 44,999$ and one (20\%) had an income of $\$ 15,000-\$ 29,999$ (see Table 32). 
Table 32

Comparison of Total Farm Debt in 2008 to Net Cash Flow from Poultry Production Income levels

\begin{tabular}{|c|c|c|c|c|c|c|c|c|c|c|c|c|c|c|c|c|c|c|}
\hline \multirow[b]{2}{*}{ Debt Load } & \multicolumn{2}{|c|}{ Lost money } & \multicolumn{2}{|c|}{$\$ 0-\$ 14,999$} & \multicolumn{2}{|c|}{$\begin{array}{c}\$ 15,000- \\
\$ 29,999\end{array}$} & \multicolumn{2}{|c|}{$\begin{array}{l}\$ 30,000- \\
\$ 44,999\end{array}$} & \multicolumn{2}{|c|}{$\begin{array}{c}\$ 45,000- \\
\$ 59,999\end{array}$} & \multicolumn{2}{|c|}{$\begin{array}{c}\$ 60,000- \\
\$ 74,999\end{array}$} & \multicolumn{2}{|c|}{$\begin{array}{l}\$ 75,000- \\
\$ 89,999\end{array}$} & \multicolumn{2}{|c|}{$\begin{array}{c}\text { Over } \\
\$ 90,000\end{array}$} & \multicolumn{2}{|c|}{ Totals } \\
\hline & $\mathrm{N}$ & $\%$ & $\mathrm{~N}$ & $\%$ & $\mathrm{~N}$ & $\%$ & $\mathrm{~N}$ & $\%$ & $\mathrm{~N}$ & $\%$ & $\mathrm{~N}$ & $\%$ & $\mathrm{~N}$ & $\%$ & $\mathrm{~N}$ & $\%$ & $\mathrm{~N}$ & $\%$ \\
\hline $\begin{array}{l}\text { Under } \\
\$ 49,999\end{array}$ & 5 & 12.8 & 10 & 25.6 & 9 & 23.1 & 11 & 28.2 & 1 & 2.6 & 1 & 2.6 & 1 & 2.6 & 1 & 2.6 & 39 & 100.0 \\
\hline $\begin{array}{l}\$ 50,000- \\
\$ 99,999\end{array}$ & 4 & 14.8 & 8 & 29.6 & 5 & 18.5 & 5 & 18.5 & 2 & 7.4 & 2 & 7.4 & 0 & 0.0 & 1 & 3.7 & 27 & 100.0 \\
\hline $\begin{array}{l}\$ 100,000- \\
\$ 199,999\end{array}$ & 0 & 0.0 & 7 & 36.8 & 7 & 36.8 & 4 & 21.1 & 0 & 0.0 & 0 & 0.0 & 0 & 0.0 & 1 & 5.3 & 19 & 100.0 \\
\hline $\begin{array}{l}\$ 200,000- \\
\$ 299,999\end{array}$ & 2 & 18.2 & 4 & 36.4 & 2 & 18.2 & 2 & 18.2 & 1 & 9.1 & 0 & 0.0 & 0 & 0.0 & 0 & 0.0 & 11 & 100.0 \\
\hline $\begin{array}{l}\$ 300,000- \\
\$ 499,999\end{array}$ & 4 & 18.2 & 6 & 27.3 & 5 & 22.7 & 6 & 27.3 & 0 & 0.0 & 0 & 0.0 & 1 & 4.5 & 0 & 0.0 & 22 & 100.0 \\
\hline $\begin{array}{l}\$ 500,000- \\
\$ 599,999\end{array}$ & 4 & 44.4 & 1 & 11.1 & 2 & 22.2 & 1 & 11.1 & 1 & 11.1 & 0 & 0.0 & 0 & 0.0 & 0 & 0.0 & 9 & 100.0 \\
\hline $\begin{array}{l}\$ 600,000- \\
\$ 699,999\end{array}$ & 1 & 25.0 & 2 & 50.0 & 0 & 0.0 & 0 & 0.0 & 1 & 25.0 & 0 & 0.0 & 0 & 0.0 & 0 & 0.0 & 4 & 100.0 \\
\hline $\begin{array}{l}\$ 700,000- \\
\$ 799,999\end{array}$ & 1 & 33.3 & 0 & 0.0 & 1 & 33.3 & 1 & 33.3 & 0 & 0.0 & 0 & 0.0 & 0 & 0.0 & 0 & 0.0 & 3 & 100.0 \\
\hline $\begin{array}{l}\$ 800,000- \\
\$ 899,999\end{array}$ & 0 & 0.0 & 2 & 100.0 & 0 & 0.0 & 0 & 0.0 & 0 & 0.0 & 0 & 0.0 & 0 & 0.0 & 0 & 0.0 & 2 & 100.0 \\
\hline $\begin{array}{l}\$ 900,000- \\
\$ 999,999\end{array}$ & 0 & 0.0 & 2 & 100.0 & 0 & 0.0 & 0 & 0.0 & 0 & 0.0 & 0 & 0.0 & 0 & 0.0 & 0 & 0.0 & 2 & 100.0 \\
\hline $\begin{array}{l}\$ 1,000,000 \\
\text { or more }\end{array}$ & 2 & 40.0 & 0 & 0.0 & 1 & 20.0 & 2 & 40.0 & 0 & 0.0 & 0 & 0.0 & 0 & 0.0 & 0 & 0.0 & 5 & 100.0 \\
\hline Totals & 23 & 16.1 & 42 & 29.4 & 32 & 22.4 & 32 & 22.4 & 6 & 4.2 & 3 & 2.1 & 2 & 1.4 & 3 & 2.1 & 143 & 100.0 \\
\hline
\end{tabular}


Total farm debt in 2008 was also compared with the producer's age. Of respondents with debt under $\$ 49,999$, one (2.5\%) respondent each indicated they were between the age of 30 and 35 and 35 and 40 . Four respondents (10\%) each indicated they were in the age categories of 40 to 45,45 to 50 , and 70 to 75 . Three (7.5\%) producers indicated they were in the age categories of 50 to 55 and over 75 , six (15\%) indicated they were 60 to 65,65 to 70 and eight (20\%) of the respondents indicated their age group was 55 to 60 (see Table 33).

Of the respondents with a debt load of $\$ 50,000-\$ 99,999$, four respondents (14.3\%) indicated their ages were in the categories of 40 to 45,60 to 65,65 to 70 years of age Three (10.7\%) producers indicated they were 45 to 50 and 55 to 60 , two respondents (7.1\%) they were 35 to 40 and eight (28.6\%) reported they were 50 to 55.

Respondents who indicated their debt load in 2008 ranged from $\$ 100,000$ $\$ 199,999$, six (30\%) were between the age of 55 to 60 , four (20\%) were between the ages of 40 to 45 or 50 to 55 . Two (10\%) of the respondents were between the ages of 45 to 50 or 60 to 65 and one (5\%) each indicated they were between the age of 30 to 35 and 70 to 75 (see Table 33).

For producers with a debt load between $\$ 200,000-\$ 299,999$, three (30.0\%) of the respondents each reported being between 50 to 55 and 55 to 60 , two (20\%) were between the age of 60 to 65 and one producer (10\%) each indicated they were between the ages of 35 to 40 and 40 to 45 . Seven respondents (35.0\%) were between the age of 45 to 50 with a debt load of $\$ 300,000-\$ 499,999$ and three (15\%) were between the ages of 50 to 55 and 55 
to 60 . Two (10\%) respondents were between age 70 to 75 and one (5\%) respondent each indicated they were 20 to 25,25 to 30,35 to 40,40 to 45 , and 60 to 65 with a debt load of $\$ 300,000-\$ 499,999$ (see Table 33).

Respondents who indicated their debt load was $\$ 500,000-\$ 599,999$, three (30\%) reported their age was 45 to 50 and 55 to 60 , one (10\%) respondent in each category indicated their age group was 25 to 30,30 to 35,50 to 55 , and 65 to 70 . Producers who had a debt load of $\$ 600,000-\$ 699,999$ included one (25\%) respondent in each of the age categories of 25 to 30,40 to 45,45 to 50 , and 55 to 60 . One respondent (33.3\%) was included in each of the age categories of 35 to 40,60 to 65 , and 65 to 70 , with a farm debt load of $\$ 700,000-\$ 799,999$. Producers with a debt load of $\$ 800,000-\$ 899,999$ had one respondent each (50\%) in the age categories of 50 to 55 and 55 to 60 . Producers with a debt load of $\$ 900,000-\$ 999,999$ had one respondent each (50\%) in the age categories of 45 to 50 and 55 to 60 . Producers who indicated they had a $\$ 1$ million or more debt load on their farm operation had two respondents (40\%) who were 45 to 50 and one (20\%) respondent in each of the age categories of 35 to 40,55 to 60 , and 60 to 65 (see Table 33). 
Table 33

Comparison of Total Farm Debt 2008 to Producer Age

\begin{tabular}{|c|c|c|c|c|c|c|c|c|c|c|c|c|c|c|}
\hline & & $20-25$ & $25-30$ & $30-35$ & $35-40$ & $40-45$ & $45-50$ & $50-55$ & $55-60$ & $60-65$ & $65-70$ & $70-75$ & Over 75 & Total \\
\hline \multirow[t]{2}{*}{ Under $\$ 49,999$} & $\mathrm{~N}$ & 0 & 0 & 1 & 1 & 4 & 4 & 3 & 8 & 6 & 6 & 4 & 3 & 40 \\
\hline & $\%$ & 0.0 & 0.0 & 2.5 & 2.5 & 10.0 & 10.0 & 7.5 & 20.0 & 15.0 & 15.0 & 10.0 & 7.5 & 100.0 \\
\hline \multirow[t]{2}{*}{$\$ 50,000$ - $\$ 99,999$} & $\mathrm{~N}$ & 0 & 0 & 0 & 2 & 4 & 3 & 8 & 3 & 4 & 4 & 0 & 0 & 28 \\
\hline & $\%$ & 0.0 & 0.0 & 0.0 & 7.1 & 14.3 & 10.7 & 28.6 & 10.7 & 14.3 & 14.3 & 0.0 & 0.0 & 100.0 \\
\hline \multirow[t]{2}{*}{$\$ 100,000-\$ 199,999$} & $\mathrm{~N}$ & 0 & 0 & 1 & 0 & 4 & 2 & 4 & 6 & 2 & 0 & 1 & 0 & 20 \\
\hline & $\%$ & 0.0 & 0.0 & 5.0 & 0.0 & 20.0 & 10.0 & 20.0 & 30.0 & 10.0 & 0.0 & 5.0 & 0.0 & 100.0 \\
\hline \multirow[t]{2}{*}{$\$ 200,000-\$ 299,999$} & $\mathrm{~N}$ & 0 & 0 & 0 & 1 & 1 & 0 & 3 & 3 & 2 & 0 & 0 & 0 & 10 \\
\hline & $\%$ & 0.0 & 0.0 & 0.0 & 10.0 & 10.0 & 0.0 & 30.0 & 30.0 & 20.0 & 0.0 & 0.0 & 0.0 & 100.0 \\
\hline \multirow[t]{2}{*}{$\$ 300,000-\$ 499,999$} & $\mathrm{~N}$ & 1 & 1 & 0 & 1 & 1 & 7 & 3 & 3 & 1 & 0 & 2 & 0 & 20 \\
\hline & $\%$ & 5.0 & 5.0 & 0.0 & 5.0 & 5.0 & 35.0 & 15.0 & 15.0 & 5.0 & 0.0 & 10.0 & 0.0 & 100.0 \\
\hline \multirow[t]{2}{*}{$\$ 500,000-\$ 599,999$} & $\mathrm{~N}$ & 0 & 1 & 1 & 0 & 0 & 3 & 1 & 3 & 0 & 1 & 0 & 0 & 10 \\
\hline & $\%$ & 0.0 & 10.0 & 10.0 & 0.0 & 0.0 & 30.0 & 10.0 & 30.0 & 0.0 & 10.0 & 0.0 & 0.0 & 100.0 \\
\hline \multirow[t]{2}{*}{$\$ 600,000-\$ 699,999$} & $\mathrm{~N}$ & 0 & 1 & 0 & 0 & 1 & 1 & 0 & 1 & 0 & 0 & 0 & 0 & 4 \\
\hline & $\%$ & 0.0 & 25.0 & 0.0 & 0.0 & 25.0 & 25.0 & 0.0 & 25.0 & 0.0 & 0.0 & 0.0 & 0.0 & 100.0 \\
\hline \multirow[t]{2}{*}{$\$ 700,000-\$ 799,999$} & $\mathrm{~N}$ & 0 & 0 & 0 & 1 & 0 & 0 & 0 & 0 & 1 & 1 & 0 & 0 & 3 \\
\hline & $\%$ & 0.0 & 0.0 & 0.0 & 33.3 & 0.0 & 0.0 & 0.0 & 0.0 & 33.3 & 33.3 & 0.0 & 0.0 & 100.0 \\
\hline \multirow[t]{2}{*}{$\$ 800,000$ - $\$ 899,999$} & $\mathrm{~N}$ & 0 & 0 & 0 & 0 & 0 & 0 & 1 & 1 & 0 & 0 & 0 & 0 & 2 \\
\hline & $\%$ & 0.0 & 0.0 & 0.0 & 0.0 & 0.0 & 0.0 & 50.0 & 50.0 & 0.0 & 0.0 & 0.0 & 0.0 & 100.0 \\
\hline \multirow[t]{2}{*}{$\$ 900,000$ - \$999,999 } & $\mathrm{N}$ & 0 & 0 & 0 & 0 & 0 & 1 & 0 & 1 & 0 & 0 & 0 & 0 & 2 \\
\hline & $\%$ & 0.0 & 0.0 & 0.0 & 0.0 & 0.0 & 50.0 & 0.0 & 50.0 & 0.0 & 0.0 & 0.0 & 0.0 & 100.0 \\
\hline \multirow[t]{2}{*}{$\$ 1,000,000$ or more } & $\mathrm{N}$ & 0 & 0 & 0 & 1 & 0 & 2 & 0 & 1 & 1 & 0 & 0 & 0 & 5 \\
\hline & $\%$ & 0.0 & 0.0 & 0.0 & 20.0 & 0.0 & 40.0 & 0.0 & 20.0 & 20.0 & 0.0 & 0.0 & 0.0 & 100.0 \\
\hline
\end{tabular}


A comparison of the statement "I am satisfied with my business as a poultry grower" and "type of poultry produced" was performed. Of the producers who completely disagreed with the statement, nine (90\%) produced broilers and one $(10 \%)$ produced broiler breeders in their operation. Of the respondents who disagreed with the statement, 16 (94.1\%) were broiler producers and one (5.9\%) was a broiler breeder producer, of the producers who somewhat disagreed with the statement, 11 (78.6\%) were broiler producers, two (14.3\%) were broiler breeder producers and one (7.1\%) was a pullet producer. Forty-six (75.4\%) broiler producers somewhat agreed with the statement, 10 (16.4\%) broiler breeder producers and five (8.2\%) pullet producers somewhat agreed with the statement. Of the respondents who agreed with the statement, 27 (64.3\%) were broiler producers, 12 (28.6\%) were broiler breeder producers and three (7.1\%) were pullet producers. Producers who completely agreed with the statement, two (16.7\%) were broiler producers, seven (58.3\%) produced broiler breeders and three (25\%) were pullet producers (see Table 34).

Producers were given several reasons why they chose to raise poultry and asked to rank them on a Likert scale; this was compared with the statement "I am satisfied with my business as a poultry grower." When comparing the statements, eight (80\%) of respondents ranked "making more money very important," but completely disagreed with the statement "I am satisfied with my business as a poultry grower." Two (20\%) of the respondents indicated making more money was somewhat important, but completely disagreed with the statement I am satisfied with my business as a poultry grower (see Table 35). 
Table 34

Comparison of Satisfaction and Type of Poultry Produced

\begin{tabular}{|c|c|c|c|c|c|c|c|c|}
\hline & \multicolumn{2}{|c|}{ Broilers } & \multicolumn{2}{|c|}{$\begin{array}{c}\text { Broiler } \\
\text { Breeders }\end{array}$} & \multicolumn{2}{|c|}{ Pullets } & \multicolumn{2}{|c|}{ Total } \\
\hline & $\mathrm{N}$ & $\%$ & $\mathrm{~N}$ & $\%$ & $\mathrm{~N}$ & $\%$ & $\mathrm{~N}$ & $\%$ \\
\hline \multicolumn{9}{|l|}{ Completely } \\
\hline Disagree & 9 & 90.0 & 1 & 10.0 & 0 & 0.0 & 10 & 100.0 \\
\hline Disagree & 16 & 94.1 & 1 & 5.9 & 0 & 0.0 & 17 & 100.0 \\
\hline \multicolumn{9}{|l|}{ Somewhat } \\
\hline Disagree & 11 & 78.6 & 2 & 14.3 & 1 & 7.1 & 14 & 100.0 \\
\hline \multicolumn{9}{|l|}{ Somewhat } \\
\hline Agree & 46 & 75.4 & 10 & 16.4 & 5 & 8.2 & 61 & 100.0 \\
\hline Agree & 27 & 64.3 & 12 & 28.6 & 3 & 7.1 & 42 & 100.0 \\
\hline \multicolumn{9}{|l|}{ Completely } \\
\hline Agree & 2 & 16.7 & 7 & 58.3 & 3 & 25.0 & 12 & 100.0 \\
\hline
\end{tabular}

Of the producers who considered making more money very important, 13 (76.5\%) disagreed with the statement "I'm satisfied with my business as a poultry grower," and four (23.5\%) somewhat agreed. Producers who somewhat disagreed with the statement, "I'm satisfied with my business as a poultry grower," five (35.7\%) respondents felt making more money was very important, eight (57.1\%) responded it was somewhat important and one (7.1\%) indicated it was not important at all. Producers who somewhat agreed with the statement, "I'm satisfied with my business as a poultry grower," had 38 (64.4\%) producers who felt that making more money was very important in their decision to raise poultry, and 21 (35.6\%) who indicated it was somewhat important. Respondents who agreed with the statement, "I'm satisfied with my business as a poultry 
grower," had $30(73.2 \%)$ producers who felt it was very important to make more money, and 10 (24.4\%) felt it was somewhat important. Respondents who completely agreed with the statement "I'm satisfied with my business as a poultry grower," included seven (63.6\%) respondents who indicated it is very important to make more money raising poultry, and four (36.4\%) felt it was somewhat important (see Table 35).

Table 35

Comparison of Satisfaction and Reason to Raise Poultry: to Make More Money

\begin{tabular}{|c|c|c|c|c|c|c|c|c|}
\hline & \multicolumn{2}{|c|}{$\begin{array}{l}\text { Not at All } \\
\text { Important }\end{array}$} & \multicolumn{2}{|c|}{$\begin{array}{l}\text { Somewhat } \\
\text { Important }\end{array}$} & \multicolumn{2}{|c|}{$\begin{array}{c}\text { Very } \\
\text { Important }\end{array}$} & \multicolumn{2}{|c|}{ Total } \\
\hline & $N$ & $\%$ & $N$ & $\%$ & $N$ & $\%$ & $\mathrm{~N}$ & $\%$ \\
\hline \multicolumn{9}{|l|}{ Completely } \\
\hline Disagree & 0 & 0.0 & 2 & 20.0 & 8 & 80.0 & 10 & 100.0 \\
\hline Disagree & 0 & 0.0 & 4 & 23.5 & 13 & 76.5 & 17 & 100.0 \\
\hline \multicolumn{9}{|l|}{ Somewhat } \\
\hline Disagree & 1 & 7.1 & 8 & 57.1 & 5 & 35.7 & 14 & 100.0 \\
\hline \multicolumn{9}{|l|}{ Somewhat } \\
\hline Agree & 0 & 0.0 & 21 & 35.6 & 38 & 64.4 & 59 & 100.0 \\
\hline Agree & 1 & 2.4 & 10 & 24.4 & 30 & 73.2 & 41 & 100.0 \\
\hline \multicolumn{9}{|l|}{ Completely } \\
\hline Agree & 0 & 0.0 & 4 & 36.4 & 7 & 63.6 & 11 & 100.0 \\
\hline
\end{tabular}

Using a Likert scale, producers ranked their agreement with the statement "I'm satisfied with my business as a poultry grower" and the reason they began raising poultry," to have something extra to live on in my retirement." Of the producers who completely disagreed with the statement, "I'm satisfied with my business as a poultry grower," four (40\%) of the respondents indicated "to have 
something extra to live on in my retirement" was not at all important or very important in their decision to raise poultry. The statement was somewhat important to two (20\%) respondents (see Table 36).

Of those producers who disagreed with the statement, "I'm satisfied with my business as a poultry grower," $10(58.8 \%)$ indicated "to have something extra to live on in my retirement" was very important in their decision to raise poultry, four $(23.5 \%)$ responded it was somewhat important and three (17.6\%) indicated it was not at all important. For producers who somewhat disagreed with the statement, "I'm satisfied with my business as a poultry grower," six (46.2\%) believed it was very important "to have something extra to live on in my retirement" as a reason for choosing to raise poultry and seven (53.8\%) felt was somewhat important.

Producers who somewhat agreed with the statement, "I'm satisfied with my business as a poultry grower," 25 (42.4\%) indicated "to have something extra to live on my retirement" was very important, 22 (37.3\%) believed it was somewhat important and $12(20.3 \%)$ responded it was not at all important. "To have something extra to live on in my retirement" was very important to 21 (52.5\%) of respondents who agreed with the statement "I'm satisfied with my business as a poultry grower," 13 (32.5\%) felt was somewhat important and six (15.0\%) responded it was not at all important. Of the respondents who completely agreed with the statement "I'm satisfied with my business as a poultry grower," four (36.4\%) felt it was very important or somewhat important "to have 
something extra to live on my retirement," and three (27.3\%) indicated it was not at all important (see Table 36).

Table 36

Comparison of Satisfaction and Reason for Raising Poultry: Retirement Income

\begin{tabular}{|c|c|c|c|c|c|c|c|c|}
\hline & \multicolumn{2}{|c|}{$\begin{array}{l}\text { Not at All } \\
\text { Important }\end{array}$} & \multicolumn{2}{|c|}{$\begin{array}{l}\text { Somewhat } \\
\text { Important }\end{array}$} & \multicolumn{2}{|c|}{$\begin{array}{c}\text { Very } \\
\text { Important }\end{array}$} & \multicolumn{2}{|c|}{ Totals } \\
\hline & $\mathrm{N}$ & $\%$ & $\mathrm{~N}$ & $\%$ & $\mathrm{~N}$ & $\%$ & $\mathrm{~N}$ & $\%$ \\
\hline \multicolumn{9}{|l|}{ Completely } \\
\hline Disagree & 4 & 40.0 & 2 & 20.0 & 4 & 40.0 & 10 & 100.0 \\
\hline Disagree & 3 & 17.6 & 4 & 23.5 & 10 & 58.8 & 17 & 100.0 \\
\hline \multicolumn{9}{|l|}{ Somewhat } \\
\hline Disagree & 0 & 0.0 & 7 & 53.8 & 6 & 46.2 & 13 & 100.0 \\
\hline \multicolumn{9}{|l|}{ Somewhat } \\
\hline Agree & 12 & 20.3 & 22 & 37.3 & 25 & 42.4 & 59 & 100.0 \\
\hline Agree & 6 & 15.0 & 13 & 32.5 & 21 & 52.5 & 40 & 100.0 \\
\hline \multicolumn{9}{|l|}{ Completely } \\
\hline Agree & 3 & 27.3 & 4 & 36.4 & 4 & 36.4 & 11 & 100.0 \\
\hline
\end{tabular}

Using a Likert scale, producers ranked the two statements, "I am satisfied with my business as a poultry grower," and "it was the easiest way for me to get financing," cross tabulations were run to compare the two statements. For producers who completely disagreed with the statement, "I'm satisfied with my business as a poultry grower," eight (80\%) responded easy financing was not at all important in their decision to raise poultry and two respondents (20\%) indicated that it was somewhat important (see Table 37).

Of the survey respondents who disagreed with the statement, "I'm satisfied with my business as a poultry grower," 14 (82.4\%) indicated it was not 
at all important in their decision to raise poultry because it was the easiest way for them to get financing, three (17.6\%) responded it was somewhat important. The statement, "it was the easiest way for me to get financing," was not at all important to eight $(72.7 \%)$ of respondents who somewhat disagreed with the statement, "I'm satisfied with my business as a poultry grower," three (27.3\%) responded it was somewhat important (see Table 37).

Of the producers who somewhat agreed with the statement, "I'm satisfied with my business as a poultry grower," five (9.3\%) responded it was very important in their decision to raise poultry as it was the easiest way for them to get financing, 14 (25.9\%) responded it was somewhat important and 35 (64.8\%) responded it was not at all important. Of the respondents who agreed with the statement, "'I'm satisfied with my business as a poultry grower," two (5.3\%) responded it was very important in their decision to raise poultry as it was the easiest way for them to get financing, $11(28.9 \%)$ felt it was somewhat important and 25 (65.8\%) responded it was not at all important. Producers who completely agreed with the statement, "I'm satisfied with my business as a poultry grower," had three (30\%) respondents who felt the statement, "it was the easiest way for me to get financing," was somewhat important or very important in their decision to raise poultry, four (40\%) responded the statement was not at all important (see Table 37). 
Table 37

Comparison of Satisfaction and Reason for Raising Poultry: Easy Financing

\begin{tabular}{|c|c|c|c|c|c|c|c|c|}
\hline & \multicolumn{2}{|c|}{$\begin{array}{l}\text { Not at All } \\
\text { Important }\end{array}$} & \multicolumn{2}{|c|}{$\begin{array}{l}\text { Somewhat } \\
\text { Important }\end{array}$} & \multicolumn{2}{|c|}{$\begin{array}{c}\text { Very } \\
\text { Important }\end{array}$} & \multicolumn{2}{|c|}{ Totals } \\
\hline & $\mathrm{N}$ & $\%$ & $N$ & $\%$ & $N$ & $\%$ & $N$ & $\%$ \\
\hline \multicolumn{9}{|l|}{ Completely } \\
\hline Disagree & 8 & 80.0 & 2 & 20.0 & 0 & 0.0 & 10 & 100.0 \\
\hline Disagree & 14 & 82.4 & 3 & 17.6 & 0 & 0.0 & 17 & 100.0 \\
\hline \multicolumn{9}{|l|}{ Somewhat } \\
\hline Disagree & 8 & 72.7 & 3 & 27.3 & 0 & 0.0 & 11 & 100.0 \\
\hline \multicolumn{9}{|l|}{ Somewhat } \\
\hline Agree & 35 & 68.4 & 14 & 25.9 & 5 & 9.3 & 54 & 100.0 \\
\hline Agree & 25 & 65.8 & 11 & 28.9 & 2 & 5.3 & 38 & 100.0 \\
\hline \multicolumn{9}{|l|}{ Completely } \\
\hline Agree & 4 & 40.0 & 3 & 30.0 & 3 & 30.0 & 10 & 100.0 \\
\hline
\end{tabular}

A crosstab procedure was run to compare the responses "I'm satisfied with my business as a poultry grower" and the variable "to provide more financial security" which is a reason why producers decided to raise poultry. Six (66.7\%) respondents completely disagree with this statement, "I am satisfied with my business as a poultry grower," indicated it was very important to have more financial security, and three (33.3\%) respondents indicated it was somewhat important to have more financial security. Of the respondents who disagreed with the statement, "I am satisfied with my business as a poultry grower," eight (47.1\%) respondents indicated it was very important to provide more financial security, six (35.3\%) responded it was somewhat important and three (17.6\%) 
responded it was not at all important. Of the producers who somewhat disagreed with the statement, "'I'm satisfied with my business as a poultry grower," five (38.5\%) respondents indicated it was very important to provide more financial security, seven (53.8\%) responded it was somewhat important and one (7.7\%) responded more financial security was not at all important in their decision to raise poultry (see Table 38).

Thirty-one (53.4\%) of the respondents who selected to provide more financial security was very important in their decision to raise poultry, somewhat agreed with the statement, "I'm satisfied with my business as a poultry grower," while 24 (41.4\%) felt it was somewhat important and three (5.2\%) responded it was not at all important. Producers who agreed with the statement, "I am satisfied with my business as a poultry grower," also saw $28(66.7 \%)$ of the respondents indicate it was very important to provide more financial security, 10 (23.8\%) of the respondents indicated it was somewhat important and four (9.5\%) indicated it was not at all important. Producers who completely agreed with the statement, "I am satisfied with my business as a poultry grower," had seven (63.6\%) respondents consider the variable to provide more financial security very important in their decision to raise poultry, three (27.3\%)producers indicated it was somewhat important and one (9.1\%) responded indicated it was not at all important (see Table 38). 
Table 38

Comparison of Satisfaction and Reason for Raising Poultry: Financial Stability

\begin{tabular}{|c|c|c|c|c|c|c|c|c|}
\hline & \multicolumn{2}{|c|}{$\begin{array}{l}\text { Not at All } \\
\text { Important }\end{array}$} & \multicolumn{2}{|c|}{$\begin{array}{l}\text { Somewhat } \\
\text { Important }\end{array}$} & \multicolumn{2}{|c|}{$\begin{array}{c}\text { Very } \\
\text { Important }\end{array}$} & \multicolumn{2}{|c|}{ Totals } \\
\hline & $\mathrm{N}$ & $\%$ & $\mathrm{~N}$ & $\%$ & $\mathrm{~N}$ & $\%$ & $\mathrm{~N}$ & $\%$ \\
\hline \multicolumn{9}{|l|}{ Completely } \\
\hline Disagree & 0 & 0.0 & 3 & 33.3 & 6 & 66.7 & 9 & 100.0 \\
\hline Disagree & 3 & 17.6 & 6 & 35.3 & 8 & 47.1 & 17 & 100.0 \\
\hline \multicolumn{9}{|l|}{ Somewhat } \\
\hline Disagree & 2 & 7.7 & 7 & 53.8 & 5 & 38.5 & 14 & 100.0 \\
\hline \multicolumn{9}{|l|}{ Somewhat } \\
\hline Agree & 3 & 5.2 & 24 & 41.4 & 31 & 53.4 & 58 & 100.0 \\
\hline Agree & 4 & 9.5 & 10 & 23 & 28 & 66.7 & 42 & 100.0 \\
\hline \multicolumn{9}{|l|}{ Completely } \\
\hline Agree & 1 & 9.1 & 3 & 27.3 & 7 & 63.6 & 11 & 100.0 \\
\hline
\end{tabular}

A comparison of the two statements "I am satisfied with my business as a poultry grower," and a reason to enter the poultry business to diversify my existing farm operation was compared. To diversify my existing farm operation, was very important to five (50\%) of the respondents who completely disagree with the statement "'I'm satisfied with my business as a poultry grower." One (10\%) respondent indicated it was somewhat important and four (40.0\%) indicated it was not at all important. Four respondents (23.5\%) indicated it was very important to diversify my existing farm operation but disagreed with the statement, "I am satisfied with my business as a poultry grower." Seven (41.2\%) producers responded it was somewhat important and six (35.3\%) responded it was not at all important. Survey respondents who somewhat disagreed with the 
statement, "I'm satisfied with my business as a poultry grower," included four respondents (36.4\%) who indicated it was very important or somewhat important to diversify their existing farm operation, and three (27.3\%) responded it was not at all important (see Table 39).

Respondents who somewhat agreed with the statement, "I'm satisfied with my business as a poultry grower," included $23(39.7 \%)$ respondents who indicated it was very important to diversify their existing farm operation, 18 (31.0\%) indicated it was somewhat important and 17 (29.3\%) producers responded it was not at all important. Respondents who agreed with the statement, "I am satisfied with my business as a poultry grower," had six (15.0\%) respondents indicate it was very important to diversify their existing farm operation, $10(25.0 \%)$ responded it was somewhat important and $24(60.0 \%)$ indicated it was not at all important. Producers who completely agreed with the statement, "I am satisfied with my business as a poultry grower," included three (30.0\%) respondents who indicated it was very important to diversify their existing farm operation, three (30.0\%) responded it was somewhat important and four (40.0\%) indicated it was not at all important (see Table 39). 
Table 39

Comparison of Satisfaction and Reason for Raising Poultry: Diversification of Farm Operation

\begin{tabular}{lcccccccc}
\hline & \multicolumn{2}{c}{$\begin{array}{c}\text { Not at All } \\
\text { Important }\end{array}$} & \multicolumn{2}{c}{$\begin{array}{c}\text { Somewhat } \\
\text { Important }\end{array}$} & \multicolumn{2}{c}{$\begin{array}{c}\text { Very } \\
\text { Important }\end{array}$} & \multicolumn{2}{c}{ Totals } \\
\cline { 2 - 9 } & $\mathrm{N}$ & $\%$ & $\mathrm{~N}$ & $\%$ & $\mathrm{~N}$ & $\%$ & $\mathrm{~N}$ & $\%$ \\
\hline $\begin{array}{l}\text { Completely } \\
\text { Disagree }\end{array}$ & 4 & 40.0 & 1 & 10.0 & 5 & 50.0 & 10 & 100.0 \\
$\begin{array}{l}\text { Disagree } \\
\begin{array}{l}\text { Somewhat } \\
\text { Disagree }\end{array}\end{array}$ & 6 & 35.3 & 7 & 41.2 & 4 & 23.5 & 17 & 100.0 \\
$\begin{array}{l}\text { Somewhat } \\
\text { Agree }\end{array}$ & 17 & 27.3 & 4 & 36.4 & 4 & 36.4 & 11 & 100.0 \\
$\begin{array}{l}\text { Agree } \\
\begin{array}{l}\text { Completely } \\
\text { Agree }\end{array}\end{array}$ & 6 & 15.0 & 10 & 25.0 & 24 & 60.0 & 40 & 100.0 \\
\hline
\end{tabular}

A comparison of the two variables "I am satisfied with my business as a poultry grower" with "poultry production has been in my family" was conducted using crosstabs. Producers who completely disagree with the statement, "I am satisfied with my business as a poultry grower," had four (40.0\%) respondents indicate it was very important to raise poultry because poultry production had been in their family, one (10.0\%) responded it was somewhat important and five (50.0\%) responded it was not at all important. Of respondents who disagreed with the statement, "I'm satisfied with my business as a poultry grower," four (23.5\%) respondents indicated because poultry production has been in their 
family was a very important reason why they choose to raise poultry, five (29.4\%) indicated it was somewhat important and eight (47.1\%) producers responded it was not at all important. Poultry production has been in my family was one reason which influenced producers choice to raise poultry, four (36.4\%) producers responded it was very important or somewhat important in their decision, three (27.3\%) producers responded it was not at all important. These producers somewhat disagreed with the statement, "I am satisfied with my business is poultry grower (see Table 40 )."

Table 40

Comparison of Satisfaction and Reason for Raising Poultry: Family Tradition

\begin{tabular}{lcccccccc}
\hline & $\begin{array}{c}\text { Not at All } \\
\text { Important }\end{array}$ & \multicolumn{2}{c}{$\begin{array}{c}\text { Somewhat } \\
\text { Important }\end{array}$} & \multicolumn{2}{c}{$\begin{array}{c}\text { Very } \\
\text { Important }\end{array}$} & \multicolumn{2}{c}{ Totals } \\
& $\mathrm{N}$ & $\%$ & $\mathrm{~N}$ & $\%$ & $\mathrm{~N}$ & $\%$ & $\mathrm{~N}$ & $\%$ \\
\hline $\begin{array}{l}\text { Completely } \\
\text { Disagree }\end{array}$ & 5 & 50.0 & 1 & 10.0 & 4 & 40.0 & 10 & 100.0 \\
$\begin{array}{l}\text { Disagree } \\
\text { Somewhat }\end{array}$ & 8 & 47.1 & 5 & 29.4 & 4 & 23.5 & 17 & 100.0 \\
$\begin{array}{l}\text { Disagree } \\
\text { Somewhat Agree }\end{array}$ & 25 & 42.4 & 14 & 23.7 & 20 & 33.9 & 59 & 100.0 \\
Agree & 22 & 55.0 & 11 & 27.5 & 7 & 17.5 & 40 & 100.0 \\
$\begin{array}{l}\text { Completely } \\
\text { Agree }\end{array}$ & 3 & 33.3 & 2 & 22.2 & 4 & 44.4 & 9 & 100.0 \\
\hline
\end{tabular}

A comparison of the two statements, "I am satisfied with my business as a poultry grower," and the reason a producer chose to enter the poultry business which was "to be my own boss," was run. Producers who completely disagreed 
with the statement, "I am satisfied with my business as a poultry grower," indicated it was very important, to be their own boss by five (50.0\%) respondents. Two (20.0\%) producers indicated it was somewhat important to be their own boss and three (30.0\%) indicated it was not at all important. Of producers who disagreed with the statement, "I am satisfied with my business as a poultry grower," eight (47.1\%) of the respondents indicated it was very important to be my own boss when choosing to raise poultry, four (23.5\%) producers responded it was somewhat important and five (29.4\%) indicated it was not at all important. Of the producers who somewhat disagreed with the statement, am satisfied with my business as a poultry grower, five (38.5\%) of the respondents indicated it was very important or somewhat important to be my own boss when deciding to raise poultry, three (23.1\%) if the respondents indicated it was not all important See Table 41).

The respondents who somewhat agreed with the statement, "I'm satisfied with my business as a poultry grower," had 27 (45.8\%) producers indicate it was very important to be my own boss when deciding to raise poultry, 26 (44.1\%) selected it was somewhat important and six (10.2\%) indicated it was not at all important. Of producers who agree with the statement, "I'm satisfied with my business as a poultry grower," $23(57.5 \%)$ of the producers indicated it was very important to be my own boss, $7(17.5 \%)$ of the respondents indicated it was somewhat important and10 (25.0\%) indicated it was not at all important. Producers who completely agree with the statement, "I am satisfied with my business as a poultry grower," included eight (66.7\%) respondents who indicated 
it was very important to be their own boss, three (25.0\%) of the producers responded it was somewhat important and one (8.3\%) indicated it was not at all important (see Table 41).

Table 41

Comparison of Satisfaction and Reason for Raising Poultry: To be my Own Boss

\begin{tabular}{|c|c|c|c|c|c|c|c|c|}
\hline & \multicolumn{2}{|c|}{$\begin{array}{l}\text { Not at All } \\
\text { Important }\end{array}$} & \multicolumn{2}{|c|}{$\begin{array}{l}\text { Somewhat } \\
\text { Important }\end{array}$} & \multicolumn{2}{|c|}{$\begin{array}{c}\text { Very } \\
\text { Important }\end{array}$} & \multicolumn{2}{|c|}{ Totals } \\
\hline & $\mathrm{N}$ & $\%$ & $\mathrm{~N}$ & $\%$ & $\mathrm{~N}$ & $\%$ & $\mathrm{~N}$ & $\%$ \\
\hline \multicolumn{9}{|l|}{ Completely } \\
\hline Disagree & 3 & 30.0 & 2 & 20.0 & 5 & 10.0 & 10 & 100.0 \\
\hline Disagree & 5 & 29.4 & 4 & 23.5 & 8 & 47.1 & 17 & 100.0 \\
\hline \multicolumn{9}{|l|}{ Somewhat } \\
\hline Disagree & 3 & 23.1 & 5 & 38.5 & 5 & 38.5 & 13 & 100.0 \\
\hline \multicolumn{9}{|l|}{ Somewhat } \\
\hline Agree & 6 & 10.2 & 26 & 44.1 & 27 & 45.8 & 59 & 100.0 \\
\hline Agree & 10 & 25.0 & 7 & 17.5 & 23 & 57.5 & 40 & 100.0 \\
\hline \multicolumn{9}{|l|}{ Completely } \\
\hline Agree & 1 & 8.9 & 3 & 25.0 & 8 & 66.7 & 12 & 100.0 \\
\hline
\end{tabular}

A crosstab comparison of the two statements, "I satisfied with my business as a poultry grower," and producers who chose other as a reason why they began to raise poultry was developed. Of producers who completely disagreed with the statement, "I am satisfied with my business as a poultry grower," one (100\%) responded it was not at all important to select other as a reason to raise poultry. Producers who disagreed with the statement, "I am satisfied with my business as a poultry grower," three (100\%) respondents indicated that other was a reason that was very important when deciding to raise 
poultry. One producer (100\%) somewhat disagreed with the statement, "I am satisfied with my business as a poultry grower," and selected other as a very important reason as to why they choose to raise poultry. Producers who somewhat agreed with the statement, "I am satisfied with my business as a poultry grower," had three (75.0\%) respondents indicate other was a very important reason why they began to raise poultry, and one (25.0\%) selected other as a somewhat important reason. Two producers (100.0\%) agreed with the statement "I am satisfied with my business as a poultry grower," and also selected other as a very important reason why they began to raise poultry (see Table 42).

Table 42

Comparison of Satisfaction and Reason for Raising Poultry: Other

\begin{tabular}{lcccccccc}
\hline & $\begin{array}{c}\text { Not at All } \\
\text { Important }\end{array}$ & \multicolumn{2}{c}{$\begin{array}{c}\text { Somewhat } \\
\text { Important }\end{array}$} & \multicolumn{2}{c}{$\begin{array}{c}\text { Very } \\
\text { Important }\end{array}$} & \multicolumn{2}{c}{ Totals } \\
\cline { 2 - 9 } & $\mathrm{N}$ & $\%$ & $\mathrm{~N}$ & $\%$ & $\mathrm{~N}$ & $\%$ & $\mathrm{~N}$ & $\%$ \\
\hline Completely Disagree & 1 & 100.0 & 0 & 0.0 & 0 & 0.0 & 1 & 100.0 \\
Disagree & 0 & 0.0 & 0 & 0.0 & 3 & 100.0 & 3 & 100.0 \\
Somewhat Disagree & 0 & 0.0 & 0 & 0.0 & 1 & 100.0 & 1 & 100.0 \\
Somewhat Agree & 0 & 100.0 & 1 & 25.0 & 3 & 75.0 & 4 & 100.0 \\
Agree & 0 & 0.0 & 0 & 0.0 & 2 & 100.0 & 2 & 100.0 \\
Completely Agree & 0 & 0.0 & 0 & 0.0 & 0 & 0.0 & 0 & 100.0 \\
\hline
\end{tabular}

A comparison of the statement, "I am satisfied with my business as poultry grower," and income levels for 2008 were compared. Of producers who 
completely disagreed with the statement, "I am satisfied with my business as a poultry grower," five (50.0\%) lost money in 2008 , four (40.0\%) had a net cash flow of $\$ 0-\$ 14,999$ and one (10.0\%) had a net income of $\$ 15,000-\$ 29,999$. Of producers who disagreed with the statement, "I am satisfied with my business as a poultry grower," six (40.0\%) lost money in 2008 , four $(26.7 \%)$ had a net cash flow of $\$ 0-\$ 14,999$ or $\$ 15,000-\$ 29,999$ and one (6.7\%) had a net cash flow of $\$ 30,000-\$ 44,999$. Respondents who somewhat disagreed with the statement, "I am satisfied with my business as a poultry grower," had two (14.3\%) respondents indicate they lost money in 2008, six (42.9\%) made between zero dollars and $\$ 14,999$, one (7.1\%) had a net income of $\$ 15,000-\$ 29,999, \$ 45,000-\$ 59,999$ or in income over $\$ 90,000$. Three respondents (21.4\%) had a net income of $\$ 30,000-\$ 44,999$ (see Table 43).

Respondents who somewhat agreed with the statement, "I am satisfied with my business as a poultry grower," saw 10 (17.2\%) respondents indicate they lost money in 2008, 19 (32.8\%) had an income between zero dollars and $\$ 14,999,15$ (25.9\%) had an income of $\$ 15,000-\$ 29,999$ to 11 had an income level between $\$ 30,000$ and $\$ 44,999$. One (1.7\%) respondent each had an income level of $\$ 45,000-\$ 59,999, \$ 75,000-\$ 89,999$ or over $\$ 90,000$. Producers agreed with the statement, "I am satisfied with my business as a poultry grower," two (5.1\%) indicated they lost money in 2008 , or had an income of $\$ 60,000$ $\$ 74,999$. Seven (17.9\%) had an income between zero dollars and $\$ 14,999$, eight (20.5\%) had an income level of \$15,000-\$29,999, 15 (38.5\%) respondents had an income of $\$ 30,000-\$ 44,999$, four $(10.3 \%)$ had an income of $\$ 45,000-\$ 59,999$ 
and one (2.6\%) had an income of $\$ 75,000-\$ 89,999$. Of the respondents who completely agreed with the statement, "I am satisfied with my business as a poultry grower," two (16.7\%) of the respondents indicated they lost money in 2008 , or had an income of $\$ 30,000-\$ 44,999$. One (8.3\%) had an income of $\$ 0$ $\$ 14,999, \$ 60,000-\$ 74,999$ or over $\$ 90,000$ in five (41.7\%) had an income level of $\$ 15,000-\$ 29,999$ (see Table 43).

Using crosstabs, debt load on the farm operation and satisfaction with the poultry producers business were compared. Four (40.0\%) producers who completely disagree with the statement, "I am satisfied with my business as a poultry grower," had a debt load of under $\$ 49,999$, two (20.0\%) had a debt load of $\$ 50,000-\$ 99,999$ and one (10.0\%) indicated the debt load on their farm operation was either $\$ 10,000-\$ 19,999, \$ 300,000-\$ 499,999, \$ 500,000-\$ 599,999$, or $\$ 800,000-\$ 899,999$. Of producers who disagreed with the statement, "I am satisfied with my business as a poultry grower," there was one (7.1\%) respondent that the debt load for the entire operation was either under $\$ 49,999$, $\$ 200,000-\$ 299,999, \$ 700,000-\$ 799,999$ or $\$ 1$ million or more. Three (21.4\%) respondents indicated the debt load on their operation was $\$ 50,000-\$ 99,999$, or $\$ 100,000 \$ 199,999$ and two (14.3\%) indicated they are debt load was between $\$ 300,000$ and $\$ 499,999$ or $\$ 500,000-\$ 599,999$ (see Table 44). 
Table 43

Comparison of Satisfaction and Income Levels

\begin{tabular}{|c|c|c|c|c|c|c|c|c|c|c|c|c|}
\hline & \multicolumn{2}{|c|}{$\begin{array}{l}\text { Completely } \\
\text { Disagree }\end{array}$} & \multicolumn{2}{|c|}{ Disagree } & \multicolumn{2}{|c|}{$\begin{array}{l}\text { Somewhat } \\
\text { Disagree }\end{array}$} & \multicolumn{2}{|c|}{$\begin{array}{l}\text { Somewhat } \\
\text { Agree }\end{array}$} & \multicolumn{2}{|c|}{ Agree } & \multicolumn{2}{|c|}{$\begin{array}{l}\text { Completely } \\
\text { Agree }\end{array}$} \\
\hline & $\mathrm{N}$ & $\%$ & $\mathrm{~N}$ & $\%$ & $\mathrm{~N}$ & $\%$ & $\mathrm{~N}$ & $\%$ & $\mathrm{~N}$ & $\%$ & $\mathrm{~N}$ & $\%$ \\
\hline Lost Money & 5 & 50.0 & 4 & 40.0 & 2 & 14.3 & 10 & 17.2 & 2 & 5.1 & 2 & 16.7 \\
\hline$\$ 0-\$ 14,999$ & 4 & 40.0 & 4 & 26.7 & 6 & 42.9 & 19 & 32.8 & 7 & 17.9 & 1 & 18.3 \\
\hline$\$ 15,000-\$ 29,999$ & 1 & 10.0 & 4 & 26.7 & 1 & 7.1 & 15 & 25.9 & 8 & 20.5 & 5 & 41.7 \\
\hline$\$ 30,000-\$ 44,999$ & 0 & 0.0 & 1 & 6.7 & 3 & 21.4 & 11 & 19.0 & 15 & 38.5 & 2 & 16.7 \\
\hline$\$ 45,000-\$ 59,999$ & 0 & 0.0 & 0 & 0.0 & 1 & 7.1 & 1 & 1.7 & 4 & 10.3 & 0 & 0.0 \\
\hline$\$ 60,000-\$ 74,999$ & 0 & 0.0 & 0 & 0.0 & 0 & 0.0 & 0 & 0.0 & 2 & 5.1 & 1 & 8.3 \\
\hline$\$ 75,000-\$ 89,999$ & 0 & 0.0 & 0 & 0.0 & 0 & 0.0 & 1 & 1.7 & 1 & 2.6 & 0 & 0.0 \\
\hline Over $\$ 90,000$ & 0 & 0.0 & 0 & 0.0 & 1 & 7.1 & 1 & 1.7 & 0 & 0.0 & 1 & 8.3 \\
\hline Totals & 10 & 100.0 & 15 & 100.0 & 14 & 100.0 & 58 & 100.0 & 39 & 100.0 & 12 & 100.0 \\
\hline
\end{tabular}


Of the respondents who somewhat disagreed with the statement, "I am satisfied with my business as a poultry grower," 3 (21.4\%) respondents indicated the farm debt load was under $\$ 49,999, \$ 100,000-\$ 199,999, \$ 200,000-\$ 299,999$ or $\$ 600,000-\$ 600,999$. Two (14.3\%) respondents indicated their debt load was $\$ 50,000-\$ 99,999$. Survey respondents who somewhat agreed with the statement, "I am satisfied with my business as a poultry grower," saw 19 (32.8\%) respondents indicate the debt on their farm operation was under $\$ 49,999,10$ (17.2\%) had a debt load of $\$ 50,000-\$ 99,999$ and nine had a debt load of $\$ 100,000-\$ 199,999$. The respondents who agreed with the statement, "I am satisfied with my business as a poultry grower," 10 (25.0\%) had a debt load of under $\$ 49,999$ or $\$ 300,000-\$ 499,000$ and nine (22.5\%) had a debt load of $\$ 50,000-\$ 99,999$. Two (5.0\%) respondents indicated their debt load was $\$ 100,000-\$ 199,999$ and one (2.5\%) indicated they are debt load was $\$ 500,000$ $\$ 599,999, \$ 600,000-\$ 699,999, \$ 700,000$ to $799,999, \$ 900,000-\$ 999,999$ or $\$ 1$ million or more. Survey respondents who completely agreed with the statement, "I am satisfied with my business as a poultry grower," saw three (30.0\%) respondents indicate their debt load was under $\$ 49,999$, two (20.0\%) indicated the debt load on their farm operation was $\$ 50,000-\$ 99,999, \$ 100,000$ to hundred $\$ 99,999$, or $\$ 500,000-\$ 599,999$. One (10.0\%) respondent indicated their debt loaded at the end of 2008 was $\$ 300,000-\$ 499,999$ (see Table 44). 
Table 44

Comparison of Producer Satisfaction and Debt Load

\begin{tabular}{|c|c|c|c|c|c|c|c|c|c|c|c|c|}
\hline & \multicolumn{2}{|c|}{$\begin{array}{l}\text { Completely } \\
\text { Disagree }\end{array}$} & \multicolumn{2}{|c|}{ Disagree } & \multicolumn{2}{|c|}{$\begin{array}{l}\text { Somewhat } \\
\text { Disagree }\end{array}$} & \multicolumn{2}{|c|}{$\begin{array}{l}\text { Somewhat } \\
\text { Agree }\end{array}$} & \multicolumn{2}{|c|}{ Agree } & \multicolumn{2}{|c|}{$\begin{array}{l}\text { Completely } \\
\text { Agree }\end{array}$} \\
\hline & $\mathrm{N}$ & $\%$ & $\mathrm{~N}$ & $\%$ & $\mathrm{~N}$ & $\%$ & $\mathrm{~N}$ & $\%$ & $\mathrm{~N}$ & $\%$ & $\mathrm{~N}$ & $\%$ \\
\hline Under $\$ 49,999$ & 4 & 40.0 & 1 & 7.1 & 3 & 21.4 & 19 & 32.8 & 10 & 25.0 & 3 & 30.0 \\
\hline$\$ 50,000-\$ 99,999$ & 2 & 20.0 & 3 & 21.4 & 2 & 14.3 & 10 & 17.2 & 9 & 22.5 & 2 & 20.0 \\
\hline$\$ 100,000-\$ 199,999$ & 1 & 10.0 & 3 & 21.4 & 3 & 21.4 & 9 & 15.5 & 2 & 5.0 & 0 & 0.0 \\
\hline$\$ 200,000-\$ 299,999$ & 1 & 10.0 & 1 & 7.1 & 0 & 0.0 & 3 & 5.2 & 4 & 10.0 & 1 & 10.0 \\
\hline$\$ 300,000-\$ 499,999$ & 0 & 0.0 & 2 & 14.3 & 0 & 0.0 & 8 & 13.8 & 1 & 2.5 & 2 & 20.0 \\
\hline$\$ 500,000-\$ 599,999$ & 0 & 0.0 & 2 & 14.3 & 3 & 21.4 & 3 & 5.2 & 1 & 2.5 & 0 & 0.0 \\
\hline$\$ 600,000-699,999$ & 1 & 10.0 & 0 & 0.0 & 0 & 0.0 & 0 & 0.0 & 1 & 2.5 & 0 & 0.0 \\
\hline$\$ 700,000-799,999$ & 0 & 0.0 & 1 & 1.7 & 0 & 0.0 & 1 & 1.7 & 1 & 2.5 & 0 & 0.0 \\
\hline$\$ 800,000-\$ 899,999$ & 0 & 0.0 & 0 & 0.0 & 0 & 0.0 & 1 & 1.7 & 0 & 0.0 & 0 & 0.0 \\
\hline$\$ 900,000-\$ 999,999$ & 0 & 0.0 & 0 & 0.0 & 0 & 0.0 & 1 & 1.7 & 1 & 2.5 & 0 & 0.0 \\
\hline Over $\$ 1,000,000$ & 0 & 0.0 & 1 & 7.1 & 0 & 0.0 & 3 & 5.2 & 1 & 2.5 & 0 & 0.0 \\
\hline
\end{tabular}


A crosstabulation was used to compare the statement; "I am satisfied with my business as a poultry grower," and state of residence. Of the producers who completely disagreed with the statement, "I am satisfied with my business as a poultry grower," eight (80.0\%) of the respondents were from West Virginia and two (20.0\%) were from Virginia. Of the producers who disagreed with the statement "I am satisfied with my business as a poultry grower," 15 (88.2\%) of the producers indicated they were from West Virginia and two (11.8\%) were from Virginia. Of producers who somewhat disagreed with the statement "I am satisfied with my business as a poultry grower," 10 (71.4\%) indicated they were from West Virginia and four (28.6\%) were from Virginia (see Table 45).

Producers who somewhat agreed with the statement, "I am satisfied with my business as a poultry grower," saw $37(60.7 \%)$ respondents from West Virginia and 24 (39.3\%) from Virginia. Producers who agreed with the statement "I am satisfied with my business as a poultry grower," were equally split with 21 (50.0\%) being from West Virginia and Virginia and of producers who completely agreed with the statement, nine (81.8\%) respondents were from West Virginia and two (18.2\%) were from Virginia. Chi square was statistically significant at 04 with alpha >.05 (see Table 45). 
Table 45

Comparison of Producer Satisfaction and State of Residence

\begin{tabular}{lcccccc}
\hline & \multicolumn{2}{c}{ West Virginia } & \multicolumn{2}{c}{ Virginia } & \multicolumn{2}{c}{ Totals } \\
\cline { 2 - 7 } & $\mathrm{N}$ & $\%$ & $\mathrm{~N}$ & $\%$ & $\mathrm{~N}$ & $\%$ \\
\hline Completely Disagree & 8 & 80.0 & 2 & 20.0 & 10 & 100.0 \\
Disagree & 15 & 88.2 & 2 & 11.8 & 17 & 100.0 \\
Somewhat Disagree & 10 & 71.4 & 4 & 28.6 & 14 & 100.0 \\
Somewhat Agree & 37 & 60.7 & 24 & 39.3 & 61 & 100.0 \\
Agree & 21 & 50.0 & 21 & 50.0 & 42 & 100.0 \\
Completely Agree & 9 & 81.8 & 2 & 18.2 & 11 & 100.0 \\
\hline
\end{tabular}

A crosstab was used to compare the statement, "I am satisfied with my business as a poultry grower," and the gender of the respondent. Producers who completely disagreed with the statement, I am satisfied with my business as a poultry grower," had nine (90.0\%) respondents who were male, and one (10.0\%) was female. Of those who disagreed with the statement, 14 (82.4\%) were male and three (17.6\%) were female. Producers who somewhat disagreed with the statement, "I am satisfied with my business as a poultry grower," saw eleven (78.6\%) respondents who were male and three (21.4\%) were female and of those who somewhat agreed with the statement, 50 (83.3\%) were male and 10 (16.7\%) were female. Survey respondents who agreed with the statement, "I am satisfied with my business as a poultry grower," had 37 (90.2\%) respondents who were male, and four (9.8\%) who were female, and of those who completely 
agreed with the statement, eight (80.0\%) were male and two (20.0\%) were female (see Table 46).

Table 46

Comparison of Producer Satisfaction by Gender

\begin{tabular}{lrrrrrr}
\hline & \multicolumn{2}{c}{ Male } & \multicolumn{2}{c}{ Female } & \multicolumn{2}{c}{ Totals } \\
\cline { 2 - 7 } & \multicolumn{1}{c}{$\mathrm{N}$} & $\%$ & $\mathrm{~N}$ & $\%$ & $\mathrm{~N}$ & $\%$ \\
\hline Completely Disagree & 9 & 90.0 & 1 & 10.0 & 10 & 100.0 \\
Disagree & 14 & 82.4 & 3 & 17.6 & 17 & 100.0 \\
Somewhat Disagree & 11 & 78.6 & 3 & 24.4 & 14 & 100.0 \\
Somewhat Agree & 50 & 83.3 & 10 & 16.7 & 60 & 100.0 \\
Agree & 37 & 90.2 & 4 & 9.8 & 41 & 100.0 \\
Completely Agree & 8 & 80.0 & 2 & 20.0 & 10 & 100.0 \\
\hline
\end{tabular}

A comparison of the respondents' age and satisfaction with their business as a poultry grower was conducted. Producers who completely disagreed with the statement, "I am satisfied with my business as a poultry grower," were represented by one (10.0\%) respondent in each of the following age categories: 35 to 40,45 to 50,50 to 55,55 to 60 and 65 to 70 . Two (20.0\%) respondents were the age category of 40 to 45 and three (30.0\%) were age 60 to 65 (see Table 47).

Producers who disagreed with the statement, "I am satisfied with my business as a poultry grower," had one (5.9\%) respondent in each of the age categories 35 to 40,40 to 45 and 65 to 70 , five (29.4\%) were in the age category of 50 to 55 , six (35.3\%) were 55 to 60 and three (17.6\%) was 60 to 65 . 
Producers who somewhat disagreed with the statement, "I am satisfied with my business as a poultry grower," had one (7.1\%) response in each of the age categories 25 to 30 , and 70 to 75 , three (21.4\%) were 40 to 45 and 60 to 65 . Two (14.3\%) were age 50 to 55 and four (28.6\%) were 55 to 60 . Of producers who somewhat agreed with the statement "I am satisfied with my business as a poultry grower," one (1.7\%) was age 20 to 25 and over 75 . Three (5.0\%) was 35 to 40 or 70 to 75 , four (6.7\%) were 40 to 45 and five (8.3\%) were 60 to 65 . In the other age categories, 12 (20.0\%) were aged between 45 to 50,50 to 55, and 55 to 60 . Survey respondents, who agreed with the statement, "I am satisfied with my business as a poultry grower," had two (4.9\%) respondents in the age categories of 30 to 35,35 to 40 and over 75 . Six respondents (14.6\%) indicated they were in the age categories of 40 to 45,10 (24.4\%) were 45 to 50, four (9.8\%) were the age category of 50 to 55 and 60 to 65 and five (12.2\%) were 55 to 60 . Producers who completely agreed with the statement, "I am satisfied with my business as a poultry grower," had three $(27.3 \%)$ of the producers responded to the age category of 55 to 60 , and there one (9.1\%) respondent each in the categories of 25 to 30,30 to 35,35 to 40,40 to 45,45 to 50,60 to 65,65 to 70 and 70 to 75 . (see Table 47). 
Table 47

Comparison of Satisfaction and Age

\begin{tabular}{lcrrrrrrrrrrr}
\hline & \multicolumn{1}{c}{$\begin{array}{c}\text { Completely } \\
\text { Disagree }\end{array}$} & \multicolumn{2}{c}{ Disagree } & \multicolumn{2}{c}{$\begin{array}{c}\text { Somewhat } \\
\text { Disagree }\end{array}$} & \multicolumn{2}{c}{$\begin{array}{c}\text { Somewhat } \\
\text { Agree }\end{array}$} & \multicolumn{2}{c}{ Agree } & \multicolumn{2}{c}{$\begin{array}{c}\text { Completely } \\
\text { Agree }\end{array}$} \\
\hline & $\mathrm{N}$ & \multicolumn{1}{c}{$\%$} & \multicolumn{1}{c}{$\mathrm{N}$} & \multicolumn{1}{c}{$\%$} & \multicolumn{1}{c}{$\mathrm{N}$} & \multicolumn{1}{c}{$\%$} & $\mathrm{~N}$ & $\%$ & $\mathrm{~N}$ & $\%$ & $\mathrm{~N}$ & $\%$ \\
\hline $20-25$ & 0 & 0.0 & 0 & 0.0 & 0 & 0.0 & 1 & 1.7 & 0 & 0.0 & 0 & 0.0 \\
$25-30$ & 0 & 0.0 & 0 & 0.0 & 1 & 1.7 & 0 & 0.0 & 0 & 0.0 & 1 & 9.1 \\
$30-35$ & 0 & 0.0 & 0 & 0.0 & 0 & 0.0 & 0 & 0.0 & 2 & 4.9 & 1 & 9.1 \\
$35-40$ & 1 & 10.0 & 1 & 5.9 & 0 & 0.0 & 3 & 5.0 & 2 & 4.9 & 1 & 9.1 \\
$40-45$ & 2 & 20.0 & 1 & 5.9 & 3 & 21.4 & 4 & 6.7 & 6 & 14.6 & 1 & 9.1 \\
$45-50$ & 1 & 10.0 & 0 & 0.0 & 0 & 0.0 & 12 & 20.0 & 10 & 24.4 & 1 & 9.1 \\
$50-55$ & 1 & 10.0 & 6 & 29.4 & 2 & 14.3 & 12 & 20.0 & 4 & 9.8 & 0 & 0.0 \\
$55-60$ & 1 & 10.0 & 6 & 35.3 & 4 & 28.6 & 12 & 20.0 & 5 & 12.2 & 3 & 27.3 \\
$60-65$ & 3 & 30.0 & 3 & 17.6 & 3 & 21.4 & 5 & 8.3 & 4 & 9.8 & 1 & 9.1 \\
$65-70$ & 1 & 10.0 & 1 & 5.9 & 0 & 0.0 & 7 & 11.7 & 3 & 7.3 & 1 & 9.1 \\
$70-75$ & 0 & 0.0 & 0 & 0.0 & 1 & 7.1 & 3 & 3.0 & 3 & 7.3 & 1 & 9.1 \\
Over 75 & 0 & 0.0 & 0 & 0.0 & 0 & 0.0 & 1 & 1.7 & 2 & 4.9 & 0 & 0.0 \\
Totals & 10 & 100.0 & 16 & 100.0 & 14 & 100.0 & 64 & 100.0 & 41 & 100.0 & 11 & 100.0 \\
\hline
\end{tabular}




\section{CHAPTER V}

\section{Summary, Conclusions, and Recommendations}

\section{Problem Statement}

The poultry industry in West Virginia and Virginia is a vital part to the rural local economies that depend on the jobs produced by these industries, as well as, the farm income that enters the local economy. The producers have not been given an opportunity for some time to tell an outside group how they feel about their chosen occupation and raising contract poultry in the current economy. This study will give producers that chance to improve producer relations in the poultry producing regions of Virginia and West Virginia. In order to improve the poultry industry in West Virginia and Virginia, the producers need an opportunity to express their opinions on how they feel about the poultry industry, their income and their company.

\section{Purpose of Study}

The purpose of this study was to provide producers an opportunity to express their attitudes about raising poultry under contract. Contract producers were given the opportunity to provide feedback on their companies' communication, payment structure and grower relations.

\section{Objectives of Study}

The focus of this project was to determine satisfaction of contract poultry producers in West Virginia and Virginia. Producers raise birds under a flock to flock contract and through this study have been given the opportunity to voice their opinions about their choices and how it has affected their family income. 
The objectives of this study were::

1. Determine satisfaction of contract poultry producers compared to type of poultry raised.

2. Determine reasons why poultry producers began raising contact poultry and if it impacts their satisfaction.

3. Determine whether having an off farm income affects a producer's satisfaction with raising poultry.

4. Determine if producer opinions of their integrators, performance, and other factors affect production and does this impact producer satisfaction?

5. What are the impacts of debt load and income on poultry operations and does this impact producer satisfaction?

6. Do specific demographics impact producer satisfaction with raising contract poultry?

\section{Summary}

The sample population for this study consisted of 383 West Virginia and Virginia poultry producers whose names and addresses were provided by their integrator. Of the 383 surveys mailed, $161(42 \%)$ were returned. The research questions will be addressed using the research objectives.

1. Determine satisfaction of contract poultry producers compared to type of poultry raised.

When reviewing the data, the pullet and broiler breeder producers show an overall higher level of satisfaction than the broiler producers. There was only one pullet producer who ranked their satisfaction with 
raising poultry in a disagree category and four broiler breeder producers indicated some type of disagreement with the statement, "I am satisfied with my business as a poultry producer."

2. Determine reasons why poultry producers began raising contact poultry and if it impacts their satisfaction.

Poultry producers had many reasons why they began to raise poultry under contract. Most producers indicated "To make more money" as the most important reason they began raising poultry. This variable had the highest level of importance to the majority of producers who responded to the survey. Producers were also looking for financial security to most producers, which had the second highest level of importance to producers who responded to the survey.

Other variables that showed high levels of importance to producers when deciding to raise poultry was the ability to be their own boss and to have something extra to live on in their retirement which also had high levels of importance to many respondents. Several producers wanted to diversify their existing operation and have the ability to enable their family to work together. These variable showed high levels of importance but was also not at all important to many producers as well. Variables that did not have high levels of importance were easy financing of which many producers indicated it was not at all important and family history of poultry production. 
3. Determine whether having an off farm income affects a producer's satisfaction with raising poultry.

Most producers who responded to the survey did not work off the farm, although their spouses had a higher incidence of employment off the farm. The producers who work off the farm are likely to be employed full time and are likely to have insurance provided by off farm employment.

4. Determine if producer opinions of their integrators, performance, and other factors affect production and does this impact producer satisfaction?

The majority of producers had very high levels of agreement when asked how they felt about information on flock management, their service persons judgment of their work, and their understanding of their contact. Producers also strongly agreed that chick and feed quality impacted their pay more than the quality of their work.

They also showed high levels of agreement with their ability to complain or speak freely to their company, support with flock problems, and the calculations on their settlement sheet, their satisfaction with raising poultry, their present company and their optimism of the future of the poultry industry. Producers also strongly agreed with their service person taking time to help them, providing written evaluations, and keeping promises. They also strongly agreed that chicks and feed are delivered in a timely manner, the chick count is accurate and that the catching crew does a good job. They believed that raising poultry was a good decision for them. Producers agreed with the statements they would 
participate in programs that would increase their income or improve production on their operation.

Producers showed moderate or low levels of agreement with the statements that they believe that raising poultry takes more time than they expected, contract renewal is dependent on new housing or major improvements, the company's ability to understand grower concerns and to respond helpfully, the information provided by the company about new technologies.

Producers showed low levels of agreement with the statement their service person was hard to contact between farm visits, that they are charged for feed they did not receive and that feed is not credited after being emptied from their bins. They also indicated some agreement when asked if they were left without birds long enough to hurt them financially. They were also moderately satisfied with their business as a poultry grower and their relationship with their present company.

Producers disagreed with the statements relating to encouraging others to enter the poultry business, that the company suggests they purchase equipment from particular vendors, the company's concern about the producers ability to increase profit, the producers ability to consider themselves an equal partner with their integrator and that the industry needs more government regulation.

5. What are the impacts of debt load and income on poultry operations and does this impact producer satisfaction? 
A majority of farm operations owe less than $\$ 499,999$ on their farm operation. The majority of producers reported their 2008 income was below $\$ 44,999$ and the income from their poultry operations account for less than half of the total farm income. The majority of producers also do not produce other crops or livestock that would account for more than 50\% of their gross farm income. Producers who responded to the survey settle average or better slightly more than half the time. When asked if their income levels were what they expected, a slight majority of producers said yes. Of producers who said their income was not what they expected, the highest number indicated it was because their operating costs rose faster than expected. They also indicated that chick and feed quality has impacted their income along with the length of their layout periods. A majority of the producers indicated no or they did not know if their contact terms had been changed to increase net pay.

6. Do specific demographics impact producer satisfaction with raising contract poultry?

The majority of survey respondents were between the ages of $45-$ 60 while the fewest number of respondents reported being less than 40 or over 75. A majority of the respondents were high school graduates although almost an equal number of producers reported some form of higher education. The majority of the respondents were males who resided in the state of West Virginia. There was a significance difference in the producer's state of residence and their satisfaction with raising poultry. 


\section{Conclusions}

Overall, producers are satisfied with their decision to raise poultry under contract; a majority of the respondents were in agreement that they were satisfied with their business as a poultry producer. This supports the findings of Ilvento and Watson (1998) and Schrader and Wilson (2001)

When comparing the research of Schrader and Wilson (2001) and the results of the current study, producers have shown a slight increase in income levels, but the number of producers who reported they lost money also increased. Results for farm operations with a debt load of less than $\$ 200,000$ were consistent from both studies, although in the current study, there was an increase in the debt loading when evaluating high debt loads on farm operations.

When comparing Schrader and Wilson (2001), the percentage of producers who understood the calculations on their settlement sheet and their understanding of their contacts increased. Producer responses saw no change in the 2001 Schrader and Wilson study and the current study when asked if raising poultry has been a good decision for them, but there was an increase in the number of producers who would encourage others to raise poultry. Overall when comparing the two studies, there has been slight gains in almost all areas of agreement on behalf of the producers.

When comparing the study results with Ilvento and Watson (1998), there was almost no change in the satisfaction of the respondents. There was a slight decrease in the producers' satisfaction with their present company and a slight increase in satisfaction of income received from the poultry operation. There are 
fewer producers who responded that would like to see more government regulation for the industry and fewer producers who would recommend the poultry business to someone who was interested. Although there have been many changes in the industry and changes in the economy, the changes do not appear to have negatively impacted producer satisfaction.

\section{Recommendations}

Producers overwhelming agreed with the statements they would participate in programs that would increase their income or improve production on their operation, however, according to industry trade groups and the integrators, very few producers turn out for programs that can provide this information. I would recommend future research on why producers will or will not participate in educational programs.

It would also be important to determine what educational needs producers would like to focus on, from previous studies to this survey, debt loads have risen on farm operations and income has remained comparable. There is a need to determine if there are practices or educational programs that can be developed to assist producers to increase income levels in the future.

There was a significant difference in the satisfaction level of producers in West Virginia and Virginia. The recommendation for the integrator is to evaluate ways to improve the level of satisfaction. Since the development and implementation of this study, there have been management changes in the West Virginia complex that may impact producer satisfaction. Additional research will 
be needed in the future to see if the management changes have impacted producer satisfaction.

Additional research is needed to look at producers' feelings about debt loading and ways to increase profitability and farm operations. Additional research needs to be conducted in the future to determine impacts of new factors such as forthcoming regulations on producer satisfaction.

Time management was cited as one reason producers felt their income levels were not where they should be, educational programs should be developed to assist producers with time management skills to help them improve their poultry operations.

Producers continually cited that their expenses have tripled in the past 1020 years, additional research is needed to look at the expense sheets and base pay of producers and the cost of utilities and other inputs to determine if these statements can be documented with data. 


\section{REFERENCES}

Aho, P. (2009, January). The fall of Pilgrim's Pride. WATT Poultry, 10-1, pp. 1416.

Ary, D., Jacobs, L. C., Razavieh, A., \& Sorensen, C. (2006). Introduction to research in education. Belmont, CA: Thomson Wadsworth.

Cunningham, D. (1997). Contract broiler grower returns: a long-term assessment. Journal of Applied Poultry Research,6, 267-273.

Cunningham, D. (2008, May). Guide for prospective contract broiler producers. Retrieved September 2009, from University of Georgia Extension: http://pubs.caes.uga.edu/caespubs/pubcd/B1167.htm.

Cunningham, D. L. (2009A). A comparison of farm incomes for poultry and nonpoultry producing counties in south Georgia. Athens, GA: University of Georgia Cooperative Extension.

Cunningham, D. L. (2009B). Cash flow estimates for contract broiler production in Georgia: a 20 year analysis. Athens, GA: The University of Georgia Cooperative Extension.

Cunningham, D. L., \& Fairchild, B. D. (2009). 2009-2010 broiler production systems in Georgia costs and returns analysis. Athens, GA: The University of Georgia Cooperative Extension.

Dillman, D. (2000). Mail and internet surveys the tailored design method. New York, New York: John Wiley \& Sons.

Fernandez-Cornejo, J., Mishra, A., Nehring, R., Hendricks, C., Southern, M., \& Gregory, A. (2007). Off-farm income, technology adoption and farm 
income performance. (ERS Report Number 36) Washington DC: USDA Economic Research Service.

Goodwin, H. (2005). Location of production and consolidation in the processing industry. Journal of Agriculture and Applied Economics,37, 339-346.

Goodwin, H. (2001, Summer). What do poultry growers think? AVIAN Advice 3(3), pp. 4-7.

Ilvento, T., \& Watson, A. (1998). Poultry growers speak out! A closer look at Delmarva poultry growers. Dover, DE: University of Deleware College of Agriculture and Natural Resouces.

MacDonald, J. M. (2008). The economic organization of US broiler production.

(Economic Information Bulletin No. EIB-38) Washinton DC: USDA Economic Research Service.

National Agriculture Statistics Service. (2007). Agriculture statisitics. Washington DC: United States Department of Agriculture.

Robinson, J. P., Shaver, P. R., \& Wrightsman, L. S. (1991). Criteria for scale selection and evaluation. In J. P. Robinson, P. R. Chaver, \& L. S. Wrightsman (Eds.), Measures of personality and soicial psychological attitudes (pp. 1-16). New York: Academic Press.

Schrader, L., \& Wilson, J. W. (2001). Broiler grower survey report. Retrieved June 2 2009, from http://www.flaginc.org/topics/pubs/poultry/poultryrpt.pdf Virginia Poultry Federation. (2007). Virginia poultry industry facts and figures 2007. Retrieved September 10 2009, from http://www.vapoultry.com/facts.asp 
APPENDICES 
APPENDIX A

Cover Letter 
June 29, 2009

Dear Poultry Producer:

Over the past several years, the poultry industry has seen many ups and downs and faces many challenges. There has been uncertainty in the industry, and producers have many feelings about the direction of raising poultry in West Virginia. It is important to have a clear understanding of the issues and problems facing poultry growers.

I am Christina Richmond, a graduate student in Agriculture and Extension Education at West Virginia University. Under the direction of my advisor, Dr. Deborah A. Boone, I am conducting a research study to explore satisfaction of poultry producers in West Virginia. The results of this study will be used to prepare a thesis to partially fulfill the requirements for a Masters of Science degree in Agriculture and Extension Education at West Virginia University. West Virginia University's IRB acknowledgement of this research is on file.

Your participation in this research is completely voluntary. You may stop filling out this survey at any time or skip any questions that you do not wish to answer. However, the completion of this survey is vital to the success of this study. The survey should only take you about 30 minutes and your results will be held as confidential as possible. There are no penalties if you choose not to participate. You will notice a code number at the bottom left hand corner of your return envelope. This number is only used to keep track of non-respondents and will be destroyed before the data are analyzed making it impossible to track your individual responses. . No individual data will be shared with your integrator or others outside of this research project.

Please place the completed questionnaire in the self addressed pre-paid envelope and drop it into the mail box by August 15, 2009. Thank you, we appreciate your time and efforts. If you have any questions or problems, please call me at 304-257-5236.

Sincerely,

Christina Richmond Graduate Student
Deborah A. Boone, Ph.D. Assistant Professor 


\section{APPENDIX B}

Follow-up Cover Letter 
August 16, 2009

Dear Poultry Producer:

Several weeks ago, you received a survey, seeking your input on your satisfaction as a poultry grower in West Virginia. You input is vital to this study and your participation is appreciated. I hope you will take a few minutes to fill out the survey and return it in the postage paid envelope.

I am Christina Richmond, a graduate student in Agriculture and Extension Education at West Virginia University. Under the direction of my advisor, Dr. Deborah A. Boone, I am conducting a research study to explore differences among agricultural education programs throughout the nation. The results of this study will be used to prepare a thesis to partially fulfill the requirements for a Master's of Science degree in Agriculture and Extension Education at West Virginia University. West Virginia University's IRB acknowledgement of this research is on file.

Your participation in this research is completely voluntary. You may stop filling out this survey at any time or skip any questions that you do not wish to answer. However, the completion of this survey is vital to the success of this study. The survey should only take you about 20 minutes and your results will be held as confidential as possible. There are no penalties if you choose not to participate. You will notice a code number at the bottom left hand corner of your return envelope. This number is only used to keep track of non-respondents and will be destroyed before the data are analyzed making it impossible to track your individual responses. No individual data will be shared with your integrator or others outside of this research project.

Please place the completed questionnaire in the self addressed pre-paid envelope and drop it into the mail box by August 31, 2009. Thank you, we appreciate your time and efforts. If you have any questions or problems, please call me at 304-257-5236.

Sincerely,

Christina Richmond Graduate Student
Deborah A. Boone, Ph.D. Associate Professor 


\section{APPENDIX C}

Instrument 


\title{
Contract Poultry Producer Satisfaction Survey
}

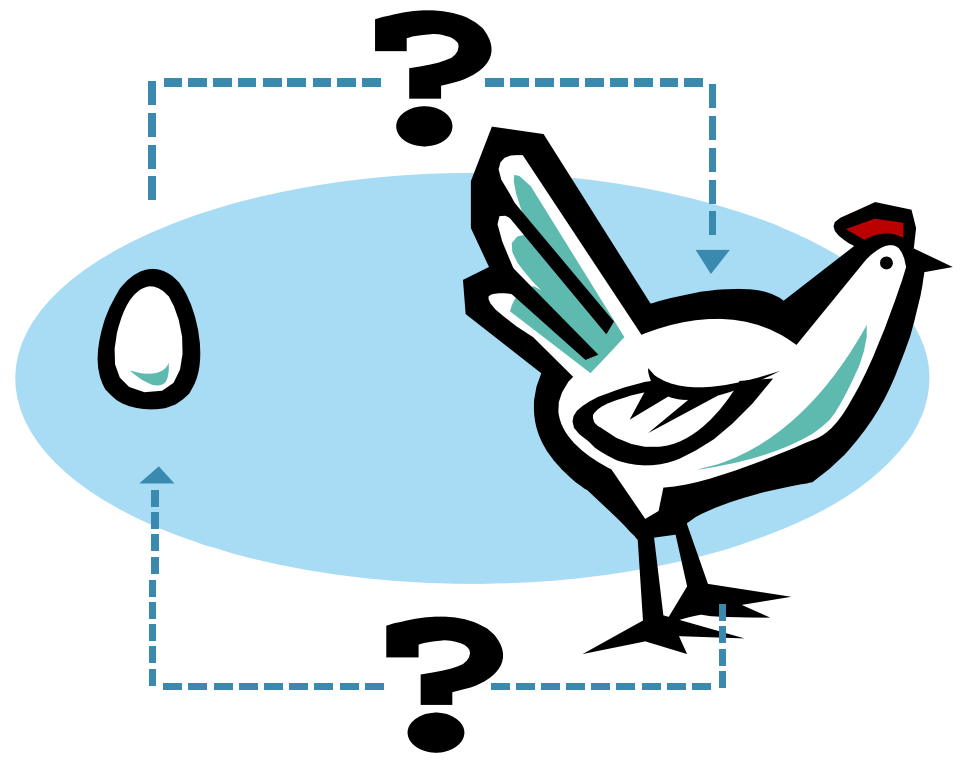

\author{
Christina Richmond \\ Graduate Student \\ Agriculture and Extension Education \\ Davis College of Agriculture, Forestry and Consumer Sciences \\ West Virginia University \\ Morgantown, WV 26506
}




\section{Contract Poultry Producer Satisfaction Survey}

1. Is this operation currently engaged in contract poultry production?

a. Yes (proceed to question 2)

2. No (skip to question 3) If yes, please indicate what type of poultry you produce.

a. Broilers

b. Broiler Breeders

c. Pullets

3. If no, please indicate which of the following applies to you; and return the survey. (check all that apply)

a. This operation has never been engaged in poultry production

b. We decided to close the poultry operation

c. Contract was not renewed by poultry integrator

d. Poultry operation was sold or rented out

e. Other (please specify)

4. How many years have you been raising poultry under contract?

5. Please indicate your occupation prior to becoming a poultry grower?

a. Operating a farm

b. Working off the farm as:

c. Homemaker

d. Completing my high school education

e. Completing my college education

f. Not working/retired

g. Other (Please Specify): 
Instructions: The following is a list of reasons people enter into poultry production. Using the scale below please circle the number that corresponds to the level of importance with which each reason impacted your decision to enter the poultry profession.

(3 = Very Important, 2 = Somewhat Important, or 1 = Not at all Important)

\begin{tabular}{|l|c|c|c|}
\hline Reasons for Entering Poultry Profession & $\begin{array}{c}\text { Very } \\
\text { Important }\end{array}$ & $\begin{array}{c}\text { Somewhat } \\
\text { Important }\end{array}$ & $\begin{array}{c}\text { Not at All } \\
\text { Important }\end{array}$ \\
\hline 6. To make more money & 3 & 2 & 1 \\
\hline $\begin{array}{l}\text { 7. To have something extra to live on in } \\
\text { my retirement }\end{array}$ & 3 & 3 & 2 \\
\hline $\begin{array}{l}\text { 8. It was the easiest way for me to get } \\
\text { financing }\end{array}$ & 3 & 2 & 1 \\
\hline $\begin{array}{l}\text { 9. To provide more financial security } \\
\text { 10. To diversify my existing farm } \\
\text { operation }\end{array}$ & 3 & 2 & 1 \\
\hline $\begin{array}{l}\text { 11. Poultry production has been in my } \\
\text { family }\end{array}$ & 3 & 2 & 1 \\
\hline 12. To enable my family to work together & 3 & 2 & 1 \\
\hline 13. To be my own boss & 3 & 2 & 1 \\
\hline $\begin{array}{l}\text { 14. Other (Please specify) } \\
\text { - }\end{array}$ & 3 & 2 & 1 \\
\hline
\end{tabular}

Instructions: When you first began to think about growing poultry for a living, where did you get information about how much income you could expect to earn? Using the following scale please circle the number that corresponds to the degree of importance each information source had on your decision to enter the poultry profession.

(3 = Very Important, 2 = Somewhat Important, or 1 = Not at all Important)

\begin{tabular}{|l|c|c|c|}
\hline Source of Information & $\begin{array}{c}\text { Very } \\
\text { Important }\end{array}$ & $\begin{array}{c}\text { Somewhat } \\
\text { Important }\end{array}$ & $\begin{array}{c}\text { Not at all } \\
\text { Important }\end{array}$ \\
\hline 15. Integrator & 3 & 2 & 1 \\
\hline 16. Family Member & 3 & 2 & 1 \\
\hline
\end{tabular}




\begin{tabular}{|l|c|c|c|}
\hline Source of Information & $\begin{array}{c}\text { Very } \\
\text { Important }\end{array}$ & $\begin{array}{c}\text { Somewhat } \\
\text { Important }\end{array}$ & $\begin{array}{c}\text { Not at all } \\
\text { Important }\end{array}$ \\
\hline 17. Other poultry growers & 3 & 2 & 1 \\
\hline 18. Farm Credit Services & 3 & 2 & 1 \\
\hline 19. Farm Service Agency & 3 & 2 & 1 \\
\hline 20. Extension Service & 3 & 2 & 1 \\
\hline 21. Poultry Association & 3 & 2 & 1 \\
\hline $\begin{array}{l}\text { 22. Other Farm Organizations } \\
\text { (Please specify) }\end{array}$ & 3 & 2 & 1 \\
\hline \begin{tabular}{l} 
23. Other (Please specify) \\
24. Other (Please specify) \\
\hline
\end{tabular} & 3 & 2 & 1 \\
\hline
\end{tabular}

Instructions: Please read each question completely and place a check mark in front of the appropriate response or provide an answer where indicated.

25. Do you currently have an off farm job?

a. Yes (proceed to question 26)

b. No (skip to question 28)

26. If yes, what is your off farm job?

27. Is your off farm job full time or part-time?

a. Full Time

b. Part Time

28. Do you work on your farm raising crops or livestock in addition to raising poultry?
a. Yes
b. No

29. Are you currently married or living with a partner?

a. Yes (proceed to question 30)

b. No (skip to question 33) 
If yes, does your spouse or partner help with crop or livestock production on your farm other than what might be needed for the poultry operation?

a. Yes

b. No

30. Does your spouse or partner work off the farm?

a. Yes (proceed to question 32)

b. No (skip to question 33)

31. If yes, what is your spouse's off farm job?

32. Do you have health insurance for your family?

a. Yes, provided by off farm job

b. Yes, individual policy

c. Yes, group policy

d. No

33. How many paid employees do you have on your operation?

a. Total number of paid employees

b. Number of part time paid employees

c. Number of full time paid employees

Instructions: How much work does it take to run your poultry operation? Please indicate how many hours are worked by you, other members of your household and hired workers during each of the following times?

\begin{tabular}{|l|l|l|l|}
\hline & $\begin{array}{c}\text { Your hours } \\
\text { per day } \\
\text { household } \\
\text { hours per } \\
\text { day }\end{array}$ & $\begin{array}{c}\text { Other } \\
\text { workers } \\
\text { hours per } \\
\text { day }\end{array}$ \\
\hline $\begin{array}{c}\text { 34. During the first two weeks after you get } \\
\text { your birds }\end{array}$ & & & \\
\hline 35. During the rest of the production period & & & \\
\hline 36. During preparation for each new flock & & & \\
\hline 37. During each major cleanout & & & \\
\hline
\end{tabular}


Instructions: Using the following scale please circle the letters that indicate your level of agreement with each of the following statements. (CA = Completely Agree, $\mathrm{A}=$ Agree, $\mathrm{SA}=$ Somewhat Agree, $\mathrm{SD}=$ Somewhat Disagree, $\mathrm{D}=$ Disagree, $\mathrm{CD}=$ Completely Disagree)

\begin{tabular}{|c|c|c|c|c|c|c|}
\hline & D. & 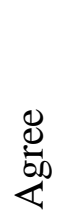 & 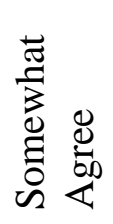 & 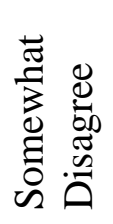 & 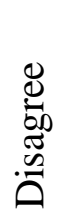 & 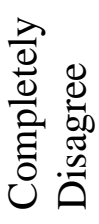 \\
\hline $\begin{array}{l}\text { 38. My company provides me with helpful } \\
\text { information about flock management. }\end{array}$ & CA & A & SA & SD & $\mathrm{D}$ & CD \\
\hline $\begin{array}{l}\text { 39. I feel free to complain to my company } \\
\text { if I have a problem. }\end{array}$ & CA & A & SA & SD & $\mathrm{D}$ & CD \\
\hline $\begin{array}{l}\text { 40. My service person is a good judge of } \\
\text { the quality of my work. }\end{array}$ & CA & A & SA & SD & $\mathrm{D}$ & CD \\
\hline $\begin{array}{l}\text { 41. I have made a real effort to read and } \\
\text { understand my contract. }\end{array}$ & CA & A & SA & SD & $\mathrm{D}$ & CD \\
\hline 42. I understand the terms of my contract. & CA & A & SA & SD & $\mathrm{D}$ & CD \\
\hline $\begin{array}{l}\text { 43. I understand the calculations on my } \\
\text { settlement sheet. }\end{array}$ & CA & A & SA & SD & $\mathrm{D}$ & $\mathrm{CD}$ \\
\hline $\begin{array}{l}\text { 44. The settlement method provides me a } \\
\text { good incentive to work hard. }\end{array}$ & CA & A & SA & SD & $\mathrm{D}$ & $\mathrm{CD}$ \\
\hline $\begin{array}{l}\text { 45. My pay depends more on the quality of } \\
\text { chicks supplied by the company than } \\
\text { on the quality of my work. }\end{array}$ & CA & A & SA & SD & $\mathrm{D}$ & CD \\
\hline $\begin{array}{l}\text { 46. My pay depends more on the quality of } \\
\text { the feed supplied by the company than } \\
\text { on the quality of my work. }\end{array}$ & CA & A & SA & SD & $\mathrm{D}$ & CD \\
\hline
\end{tabular}




\begin{tabular}{|c|c|c|c|c|c|c|}
\hline & 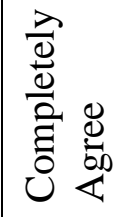 & 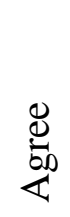 & 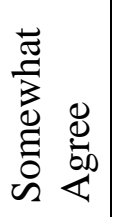 & 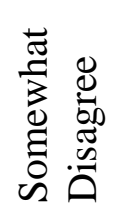 & 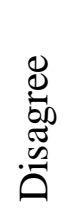 & 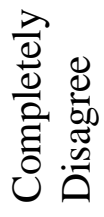 \\
\hline $\begin{array}{l}\text { 47. The time my family and I spend caring } \\
\text { for the poultry is more than my } \\
\text { company led me to expect. }\end{array}$ & CA & A & SA & SD & D & CD \\
\hline $\begin{array}{l}\text { 48. The improvements to my houses } \\
\text { suggested by my company have made } \\
\text { me better off. }\end{array}$ & CA & A & SA & SD & $\mathrm{D}$ & CD \\
\hline $\begin{array}{l}\text { 49. My company strongly suggests that } \\
\text { new equipment should be purchased } \\
\text { from particular vendors. }\end{array}$ & CA & A & SA & SD & $\mathrm{D}$ & CD \\
\hline $\begin{array}{l}\text { 50. My contract will not be renewed unless } \\
\text { I follow my company's } \\
\text { recommendations about building new } \\
\text { houses }\end{array}$ & CA & A & SA & SD & D & CD \\
\hline $\begin{array}{l}\text { 51. My contract will not be renewed unless } \\
\text { I follow my company's } \\
\text { recommendations about making major } \\
\text { improvements to my old houses. }\end{array}$ & CA & A & SA & SD & $\mathrm{D}$ & CD \\
\hline $\begin{array}{l}\text { 52. Poultry growers who are also company } \\
\text { employees should not be included in } \\
\text { the same grow-out group as others. }\end{array}$ & CA & A & SA & SD & D & CD \\
\hline $\begin{array}{l}\text { 53. Getting into poultry growing has been a } \\
\text { good decision for me. }\end{array}$ & CA & A & SA & SD & $\mathrm{D}$ & CD \\
\hline $\begin{array}{l}\text { 54. I would encourage others to become } \\
\text { poultry growers. }\end{array}$ & CA & A & SA & SD & $\mathrm{D}$ & CD \\
\hline
\end{tabular}


Instructions: Using the following scale please circle the letters that indicate your level of agreement with each of the following statements. (CA = Completely Agree, A = Agree, SA = Somewhat Agree, $\mathrm{SD}=$ Somewhat Disagree, $\mathrm{D}=$ Disagree, $\mathrm{CD}=$ Completely Disagree)

\begin{tabular}{|c|c|c|c|c|c|c|}
\hline & 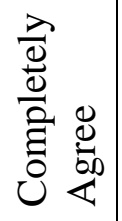 & 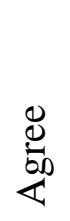 & 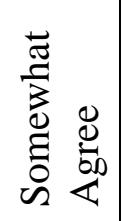 & 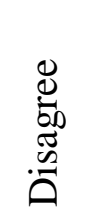 & 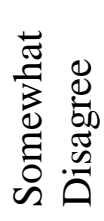 & 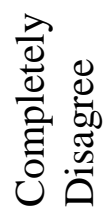 \\
\hline $\begin{array}{l}\text { 55. Company management responds } \\
\text { helpfully to my complaints. }\end{array}$ & CA & A & SA & SD & D & CD \\
\hline $\begin{array}{l}\text { 56. My service person takes time to help } \\
\text { me understand and follow } \\
\text { recommendations. }\end{array}$ & CA & A & SA & SD & D & CD \\
\hline $\begin{array}{l}\text { 57. My service person makes a written } \\
\text { evaluation after visiting my farm. }\end{array}$ & CA & A & SA & SD & D & CD \\
\hline $\begin{array}{l}\text { 58. My service person provides me with a } \\
\text { hard copy of any written evaluation. }\end{array}$ & CA & A & SA & SD & D & CD \\
\hline $\begin{array}{l}\text { 59. My service person keeps the promises } \\
\text { made to me. }\end{array}$ & CA & A & SA & SD & D & CD \\
\hline $\begin{array}{l}\text { 60. My service person is hard to contact } \\
\text { between visits. }\end{array}$ & CA & A & SA & SD & D & CD \\
\hline $\begin{array}{l}\text { 61. I am left without birds long enough to } \\
\text { hurt me financially. }\end{array}$ & CA & A & SA & SD & D & CD \\
\hline $\begin{array}{l}\text { 62. Chicks are delivered to my farm when } \\
\text { promised. }\end{array}$ & CA & A & SA & SD & D & CD \\
\hline $\begin{array}{l}\text { 63. Good quality chicks are delivered to } \\
\text { my farm. }\end{array}$ & CA & A & SA & SD & D & CD \\
\hline $\begin{array}{l}\text { 64. The chick count I am given is } \\
\text { accurate. }\end{array}$ & CA & A & SA & SD & D & CD \\
\hline
\end{tabular}




\begin{tabular}{|c|c|c|c|c|c|c|}
\hline & 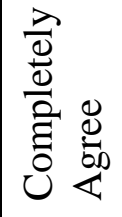 & 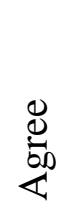 & 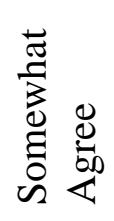 & 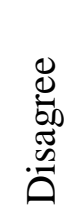 & 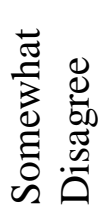 & 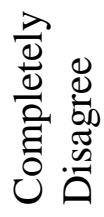 \\
\hline $\begin{array}{l}\text { 65. Birds are weighed promptly once they } \\
\text { get to the plant. }\end{array}$ & CA & A & SA & SD & D & CD \\
\hline 66. The catching crew does a good job. & CA & A & SA & SD & $\mathrm{D}$ & $\mathrm{CD}$ \\
\hline $\begin{array}{l}\text { 67. My company provides me with good } \\
\text { quality feed. }\end{array}$ & CA & A & SA & SD & D & CD \\
\hline $\begin{array}{l}\text { 68. Feed is delivered to my farm as } \\
\text { scheduled. }\end{array}$ & CA & A & SA & SD & D & CD \\
\hline $\begin{array}{l}\text { 69. I am charged for more feed than is } \\
\text { delivered. }\end{array}$ & CA & A & SA & SD & D & CD \\
\hline $\begin{array}{l}\text { 70. Feed is emptied from my bins and not } \\
\text { credited to my account. }\end{array}$ & CA & A & SA & SD & D & CD \\
\hline $\begin{array}{l}\text { 71. Growers who are company employees } \\
\text { are included in my grow-out group. }\end{array}$ & CA & A & SA & SD & $\mathrm{D}$ & CI \\
\hline
\end{tabular}

72. Thinking back over the last three years, have the terms of your contract been changed to increase your net pay?
a. Yes
b. No
c. Don't Know

73. Based on the information you received from the company when you were starting out, has your income from the poultry growing been more than you expected, about what you expected, or less than you expected?

a. More than expected (proceed to question 76)

b. About what I expected (proceed to question 76)

c. Less than expected (proceed to question 75) 
74. If less, why has your income been less than expected? (check all that apply)

a. I have received fewer chicks than promised.

b. More chicks have died than I had anticipated.

c. My layout periods are too long.

d. I have been given poor quality feed or the wrong feed.

e. I have been given poor quality chicks.

f. My birds have not received adequate veterinary care.

g. My contract terms changed.

h. My operating costs have risen faster than I expected.

i. The company required expensive improvements.

j. This business has turned out to be more complicated than I thought.

k. I never seem to have enough time to do the work that needs to be done.

l. I've lost interest in growing poultry.

m. Other (please specify):

75. At the end of 2008, what was the total farm debt on your entire operation?

$\begin{aligned} \text { a. } & \text { Under } \$ 49,999 \\ \text { b. } & \$ 50,000-\$ 99,999 \\ \text { c. } & \$ 100,000-\$ 199,999 \\ \text { d. } & \$ 200,000-\$ 299,999 \\ \text { e. } & \$ 300,000-\$ 499,999 \\ \text { f. } & \$ 500,000-\$ 599,999 \\ \text { g. } & \$ 600,000-\$ 699,999 \\ \text { h. } & \$ 700,000-\$ 799,999 \\ \text { i. } & \$ 800,000-\$ 899,999 \\ \text { j. } & \$ 900,000-\$ 999,999 \\ \text { k. } & \$ 1,000,000 \text { or more }\end{aligned}$


76. Of the total farm debt, what percent is owed on your poultry operation?
a. Less than $25 \%$
b. $25 \%$ to $49 \%$
c. $50 \%$ to $74 \%$
d. $75 \%$ or more
e. Don't Know

77. What was the net cash flow from your poultry production last year? By "net cash flow”, we mean poultry income left over after paying poultry-related expenses, such as poultry house mortgage payments, insurance, repairs, utilities and disposal of litter.

a. Lost money

b. $\$ 0-\$ 14,999$

c. $\$ 15,000-\$ 29,999$

d. $\$ 30,000-\$ 44,999$

e. $\$ 45,000-\$ 59,999$

f. $\$ 60,000-\$ 74,999$

g. $\$ 75,000-\$ 89,999$

h. Over $\$ 90,000$

78. Do you produce crops or livestock other than poultry on your farm that account for more than $50 \%$ of you gross farm income?

a. Yes

b. No

79. What percentage of your total family income last year was from the poultry operation? By "total family income" we mean income contributed by all members of your household from other farm enterprises, off-farm enterprises, off-farm jobs, rental income and the like.

a. Less than $25 \%$

b. $25 \%$ to $49 \%$

c. $50 \%$ to $74 \%$

d. $75 \%$ or more

80. How many times over the past 10 flocks have you been ranked better than average in your settlement group?

a. Number of times:

b. Don't know 
81. Some growers belong to organizations because they believe the organizations will help them manage their poultry operations better. Please indicate if you belong to any of the following organizations for this reason:

a. West Virginia Poultry Association

b. Farm Bureau

c. Virginia Poultry Federation

d. Contract Poultry Growers' Association of VA’s

e. Grange

f. Other (please specify):

Instructions: Using the following scale please circle the letters that indicates your level of agreement with each of the following statements. $(\mathrm{CA}=$ Completely Agree, $\mathrm{A}=$ Agree, $\mathrm{SA}=$ Somewhat Agree, $\mathrm{SD}=$ Somewhat Disagree, $\mathrm{D}=$ Disagree, $\mathrm{CD}=$ Completely Disagree)

\begin{tabular}{|c|c|c|c|c|c|c|}
\hline & 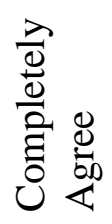 & 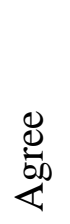 & 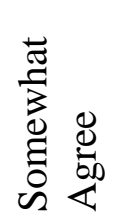 & 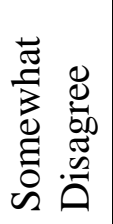 & 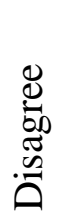 & 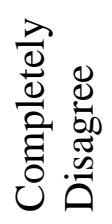 \\
\hline $\begin{array}{l}\text { 82. I am satisfied with my business as a } \\
\text { poultry grower. }\end{array}$ & CA & $\mathrm{A}$ & SA & SD & $\mathrm{D}$ & CD \\
\hline $\begin{array}{l}\text { 83. I am satisfied with my relationship with } \\
\text { my present company. }\end{array}$ & CA & $\mathrm{A}$ & SA & SD & $\mathrm{D}$ & CD \\
\hline $\begin{array}{l}\text { 84. I am satisfied with the income I receive } \\
\text { from my poultry operation. }\end{array}$ & CA & $\mathrm{A}$ & SA & SD & $\mathrm{D}$ & CD \\
\hline $\begin{array}{l}\text { 85. I am optimistic about the future of } \\
\text { WV's poultry industry. }\end{array}$ & CA & $\mathrm{A}$ & SA & SD & $\mathrm{D}$ & CD \\
\hline $\begin{array}{l}\text { 86. The poultry industry needs more } \\
\text { government regulation. }\end{array}$ & CA & $\mathrm{A}$ & SA & SD & $\mathrm{D}$ & CD \\
\hline $\begin{array}{l}\text { 87. I would recommend the poultry } \\
\text { growing business to someone who is } \\
\text { interested. }\end{array}$ & CA & A & SA & SD & $\mathrm{D}$ & CD \\
\hline
\end{tabular}

Instructions: Answer the following questions regarding all the poultry houses in your operation.

88. How many houses are currently under contract?

89. What is the age of your oldest house? 
90. What is the age of your youngest house?

91. How many houses use tunnel ventilation?

92. How many houses use negative pressure?

93. What is your maximum farm capacity in birds per flock?

Instructions: Using the following scale please circle the letters that indicates your level of agreement with each of the following statements. (CA = Completely Agree, $\mathrm{A}=$ Agree, $\mathrm{SA}=$ Somewhat Agree, $\mathrm{SD}=$ Somewhat Disagree, $\mathrm{D}=$ Disagree, $\mathrm{CD}=$ Completely Disagree)

\begin{tabular}{|c|c|c|c|c|c|c|}
\hline & 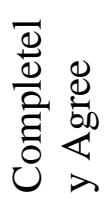 & 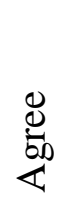 & 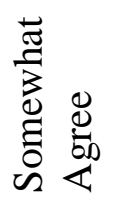 & 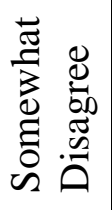 & 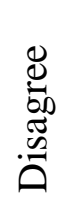 & 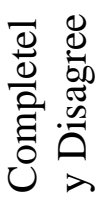 \\
\hline $\begin{array}{l}\text { 94. I can speak freely with representatives } \\
\text { of my present company. }\end{array}$ & CA & A & SA & SD & $\mathrm{D}$ & $\mathrm{CD}$ \\
\hline $\begin{array}{l}\text { 95. Company management understands } \\
\text { the concerns of growers. }\end{array}$ & CA & A & SA & SD & $\mathrm{D}$ & CD \\
\hline $\begin{array}{l}\text { 96. If I have a question, I can get a prompt } \\
\text { response from my company. }\end{array}$ & CA & A & SA & SD & $\mathrm{D}$ & CD \\
\hline $\begin{array}{l}\text { 97. I get the support I need when there is a } \\
\text { problem with my flock. }\end{array}$ & CA & A & SA & SD & $\mathrm{D}$ & CD \\
\hline $\begin{array}{l}\text { 98. My company provides information I } \\
\text { need to know. }\end{array}$ & CA & A & SA & SD & $\mathrm{D}$ & CD \\
\hline $\begin{array}{l}\text { 99. When new technology is introduced, } \\
\text { I get adequate information from my } \\
\text { poultry company with which to make } \\
\text { decisions. }\end{array}$ & CA & A & SA & SD & $\mathrm{D}$ & CD \\
\hline $\begin{array}{l}\text { 100. Communication between growers } \\
\text { and companies is adequate. }\end{array}$ & CA & A & SA & SD & $\mathrm{D}$ & CD \\
\hline $\begin{array}{l}\text { 101. My company is concerned with } \\
\text { helping me increase my profit from } \\
\text { my poultry operation. }\end{array}$ & CA & $\mathrm{A}$ & SA & SD & $\mathrm{D}$ & CD \\
\hline $\begin{array}{l}\text { 102. I consider myself a full and equal } \\
\text { business partner with my company. }\end{array}$ & CA & A & SA & SD & $\mathrm{D}$ & CD \\
\hline
\end{tabular}


Instructions: Using the following scale please circle the letters that indicates your level of agreement with each of the following statements that relate to future programs to improve the poultry industry. (CA = Completely Agree, $\mathrm{A}=$ Agree, $\mathrm{SA}=$ Somewhat Agree, $\mathrm{SD}=$ Somewhat Disagree, $\mathrm{D}=$ Disagree, $\mathrm{CD}=$ Completely Disagree)

\begin{tabular}{|c|c|c|c|c|c|c|}
\hline & 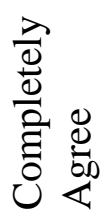 & 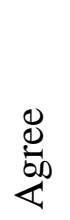 & 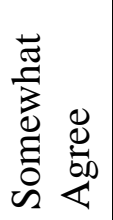 & 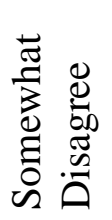 & 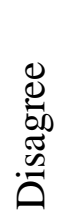 & 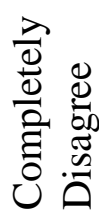 \\
\hline $\begin{array}{l}\text { 103. There should be a special company } \\
\text { program for growers who have fallen } \\
\text { below average with emphasis on } \\
\text { problem identification and } \\
\text { resolution. }\end{array}$ & CA & A & SA & SD & $\mathrm{D}$ & CD \\
\hline $\begin{array}{l}\text { 104. Educational programs are needed to } \\
\text { help producers better manage their } \\
\text { operation. }\end{array}$ & CA & A & SA & SD & D & CD \\
\hline $\begin{array}{l}\text { 105. I would attend educational programs } \\
\text { on new technologies if it would } \\
\text { improve my business. }\end{array}$ & CA & A & SA & SD & D & CD \\
\hline $\begin{array}{l}\text { 106. I would attend training on } \\
\text { management techniques if it would } \\
\text { improve my business. }\end{array}$ & CA & A & SA & SD & D & CD \\
\hline
\end{tabular}

107. What state do you reside in?
a. West Virginia
b. Virginia

108. What is your gender?
a. Male
b. Female 
109. What is your age?

a. 20-25

b. 25-30

C. $\quad 30-35$

d. $35-40$

e. $40-45$

f. $45-50$

g. $50-55$

h. $55-60$

i. $60-65$

j. $\quad 65-70$

k. $\quad 70-75$

l. Over 75

110. What was the highest level of education completed?

a. Less than High School

b. High School Graduate

c. Trade or Technical School

d. Some four-year college

e. Bachelor's degree

f. Masters degree or higher 


\title{
Comments
}

(Thank you for completing this survey and returning it in the enclosed business reply envelope)

If you have questions please contact:

\author{
Christina Richmond \\ Graduate Student \\ Agriculture and Extension Education \\ Davis College of Agriculture, Forestry and Consumer Sciences \\ West Virginia University \\ P.O. Box 6108 \\ Morgantown, WV 26506 \\ Phone: 304-257-5236 \\ Email: crichmo4@mix.wvu.edu
}




\section{APPENDIX D}

Comments 


\section{Question 6 - Reason to raise poultry: To make more money}

- To make more money for my mom and dad

\section{Question 13 - Reason to raise poultry: To be my own boss}

- You are never your own boss

\section{Question 14 - Reason to raise poultry: Other}

- More control over time

- More likely to stay in USA

- To "down" taxes on the farm land

- To be at home

- To make a living

- Purchase Farm

- Already family operation

- I wanted to tax my skills at farming

- Nice place to raise a family

- Be a stay at home mom

- To make a smaller operation more profitable

- To keep busy after retirement

- Extension of parents farm

- Be home with children

- Inherited family farm

- Houses were on farm which is why we were buying in the first place

- Second income for (husband) 


\section{Question 23 Source of information: Other}

- Worked on uncles farm at age 8 and up

- Ran poultry farm I bought

- I just wanted to farm

- Local integrator expansion

- Death of family member got me in business, Pilgrim's pride assessed me Question 41 - My service person is a good judge of the quality of my work

- Ask him or her

Question 42 - I have made a real effort to understand the terms of my contract

- I am not a lawyer

Question 44 - I understand the calculations on my settlement sheet

- Not Fair

- Do not understand at all

Question 45 - The settlement method provides me a good incentive to work hard

- No

- It used to but not any more

Question 51 - My contract will not be renewed unless I follow my company's recommendations about building new houses

- Not so far but I don't have double decks 
Question 55 - I would encourage others to become poultry growers

- Not with current conditions

- No, No, No

- Would not encourage anyone

- Depends

Question 59 - My service person provides me with a hard copy of any written evaluation

- Cannot read the writing

Question 61 - My service person is hard to contact between visits

- No comment

Question 62 - I am left without birds long enough to hurt me financially

- Yes

- Sometimes

- Winter season

- $2008-6$ flocks Normal 7 Flocks

- Much to longer

Question 63 - Chicks are delivered to my farm when promised

- But short numbers

Question 64- Good quality chicks are delivered to my farm

- Sometimes

- About half the time

- Not at all true

- Sometimes 
Question 65 - The chick count I am given is accurate

- We do not get count anymore

- How am I supposed to know

- Who knows

- Who knows

- I don't count them

Question 66 - Birds are weighed promptly once they get to the plant

- No

- Do not know

- Who knows

- Who knows

- Don't know

- Really Don't know

- I guess

- Don't know

- No way to know

Question 67 - The catching crew does a good job

- Some crews

- How about DOAs in cold weather

Question 68 - My company provides me with good quality feed

- I hope so-but how do I know

- Too fine 
Question 70 - I am charged for more feed than is delivered

- I hope not

- Do not Know

- Who knows

- Who knows

- Who knows

- No way of knowing

Question 72 - Growers who are company employees are included in my grow-out group

- I don't know

- Don't know

- No way of knowing

- Don't know

- How would I know

- Not sure

Question 73 - Thinking back over the last three years, have the terms of your contract been changed to increase your net pay?

- No, No

- That would be nice. We haven't gotten a raise in years.

- My pay has increased, but has not kept up with fuel, litter electric costs

- Expenses have tripled in the last 20 years

- Supposed to be. It appears to be they lean the way the wind blows, they are like the "they" speak with a forked tongue. 
- If the pay does not improve to compensate for the risings costs, l'll have to quit within the next year.

- My husband died and I have to hire to have work done. But I still need to make sure work is done correctly.

Question 74 - Based on the information you received from the company when you were starting out, has your income from the poultry growing been more than you expected, about what you expected, or less than you expected?

- I built my 2 poultry in 88 , it was Rockingham Poultry, a coop, the growers made pretty good money then but when Wamplers Food bought them out, "the" bought the stock. That fixed the money business

Question 75 - If less, why has your income been less than expected?

75C - My layout periods are too long

- 2-3 weeks downtime

- Recently

75D - I have been given poor quality feed or the wrong feed

- Sometimes when they experiment at my cost

75E - I have been given poor quality chicks

- Sometime this is expected 
75F - My birds have not received adequate veterinary care

- Can't complain

$75 \mathrm{H}-\mathrm{My}$ operating costs have risen faster than expected

- I am grossing about the same as I did 20 years ago, but my expenses have tripled.

- LP Gas

$75 I$ - The company requires expensive improvements

- To some people

$75 \mathrm{~K}$ - I never seem to have enough time to do the work that needs to be done

- $\mathrm{OK}$

$75 \mathrm{~L}$ - I've lost interest in growing poultry

- 80 Years old, starting to slow down some

$75 \mathrm{M}$ - other

- Income has not increased with operating costs

- Income has not increased in past ten years

- Company is selling smaller bird. Small bird means less income

- Fuel, shaving, electric increases are more than base pay

- Because of poor company management and concern and not making enough money to make ends meet

- We were not aware when you have been in this business that your pay helps pay new people coming into it 
- Company raise brooding temp from 85 to 90 . Company allows $\$ 200.00$ per house fuel and new litter per flock

- Cost and operating has tripled, but pay is still the same

- Possible -the economy

- Integrator and management changes

- Burn out

- They don't pay us enough. It's all eat up with expenses

- Cost of living expenses higher with no raises

- Income has not kept up with inflation

- Depends on time, has multiplied by $100 \%$.

Question 77 - Of the total farm debt, what percent is owed on your poultry operation

- No farm debt

- Houses are paid for

- I am debt free

Question 82f - Farm organizations producer belongs to: other

- Local Farm Association

Question 85 - I am satisfied with the income I receive from my poultry operation

- No

- Are you kidding 
Question 87 - The poultry industry needs more government regulation

- No

- Or self regulation

- If you want it screwed up -they can help

Question 88 - I would recommend the poultry growing business to someone who is interested

- No

- Depends

Question 95 - I can speak freely with representatives of my present company

- No

Question 96 - Company management understands the concerns of growers

- No

- Some do-some don't

- It changed not sure

- Trust like any politicians-act like they are listening

Question 97 - If I have a question, I can get a prompt response from my company

No

Question 100 - When a new technology is introduced, I get adequate information from my poultry company with which to make good decisions

- We do as they say 
Question 101 - Communication between growers and companies is

adequate

- No

Question 102 - My company is concerned with helping me increase my profits from my poultry operation

- No

- They are more concerned with theirs

Question 103 - I consider myself a full and equal business partner with my company

- No

Question 104 - There should be a special company program for growers who have fallen below average with emphasis on problem identification and resolution

- There will always be someone below average the way the contract is written

- There is already

Question 106 and 107 - I would attend educational programs on new technologies if it would improve my business and I would attend training on management techniques if it would improve my business

- Where 


\section{Comments}

- Being in the poultry business for 36 years and raising birds for three companies. I believe that the coop (Rockingham) had a better company and grower relationship. I believe the company has some control as to what the grower makes on his birds. Mostly by the quality of chicks and feed. When you are in the poultry business, its like having Christmas 6or 7 times a year. Each settlement you receive you never know what you will get.

- Good luck on thesis - Two respondents

- When I get farm credit paid off in 6 years. Lord willing. I'll be glad.

- Our company filed bankruptcy in December 2008. They over spent buying other companies, big shots made bad decisions

- My family has been in the poultry business for 30 years. This is the "worse" company that has ever been to work for. Yes, I would recommend someone to go into the poultry business not with

- As a contract growers, our goal with each flock is to do well. We maintain our houses and equipment, provide daily care of chicks, under direction of service of technician. We control temps, ventilation, air quality, water and litter conditions. Two determining factors, (controlled by integrator), with raising a good bird are chicks and feed quality. Feed continues to be a major issue, (poor) causing wet floors, meaning less weight gain for chicks, less lbs, less income---higher costs for grower in trying to treat floors by top dressing, heating, more ventilation and TIME. This is one of 
the issues we continue to deal with, which we attribute to be a direct result of our integrator's financial woes, not to mention the news of plant closings ---- contract growers losing everything, their dollar investments and time, we know, we are at risk, but continue to work hard each day with what we have to deal with. Hope this helps-Good luck.

- Extra hours depend on what breaks down and how long it takes to fix it. When it's hot and you're running foggers you need to check buildings often.

- Depends on who you mean by company

- The poultry industry has been good to my family

- I appreciate you asking

- Would have expanded on some answers if given space-good survey hits many important points-overall we are satisfied with our poultry operation. Although like many other enterprises in the past five to ten years, they pay has not increased with the cost to operate.

- Some questions were not answered because they did not apply to my operation

- I have grown chickens for years, before that it was turkeys, for another company, this survey would be filled with more negativity for the turkey company. They have some real problems.

- The poultry industry has been the worst investment I have ever put money into. Debt load, lies from the company, just the lack of help from the 
company. Large investments with no control on the growers part. You are a slave to the company with no way out. You are at their mercy.

- I hope this will be of help to you as you finish your education

- I'm old enough to remember a time when poultry companies and growers made money together. Not anymore.

- It's a hard business to make ends meet. We are getting paid basically same pay that has been for the past 20 years or so. ..18 and .20 per head. But the cost of raising chickens has more than tripled or more. Until most of the population is shown that you just don't go to the grocery store to buy what you need, there isn't going to be any changes and also less farmers.

- Growers should be entitled to same benefits as plant workers (insurance, 40IK, etc.) Migrant workers get better treatment than us contractors. Grower pay has not kept up with inflation. Pay broiler producers by the square foot. Provide LP gas and shavings. It works for pullet growers, so why not broiler folks? Guarantee us 7 flocks per year. That's what our mortgage payments are set up for. Quit pestering growers about updates until houses are paid for. Tell we know how to raise chickens in WV.

- The simple fact is this - the companies DO NOT care about the growers. Example - It's a known fact that some growers raise corn and soybeanssome of these growers feed that crop to their flocks, therefore those growers who don't raise their crops are at a disadvantage-this has been done. Also, I live in County, VA our birds are processed in 
Moorefield, WV which is a hour drive for a loaded truck; our birds are weighed at Moorefield. I am trying to compete against growers who are less than ten minutes from the plant; studies have been done to show birds loose between $.10 \mathrm{lb}$ to $.25 \mathrm{lb}$ every 2 hours they are transported.

- Too many sections here have side issues-true of most written or phone surveys. I normally do not do surveys for this reason. Hard to place ????? or surveys misleading unless done with eye contact. No mention of surveys and analysis to growers.

- Good luck on your thesis. Communication is the key to any successful business. 


\section{VITA}

Christina L. Richmond

\section{Education:}

August 2000

Bachelor's of Science

Agricultural and Environmental Education

West Virginia University

Morgantown, West Virginia

May 2010

Master's of Science

Agricultural and Extension Education

West Virginia University

Morgantown, West Virginia

\section{Professional Experience:}

June 2009- May 2010

West Virginia Department of Agriculture CAFO Coordinator

Regulatory and Environmental Affairs Division Moorefield, WV

September 2003-June 2009

West Virginia Department of Agriculture Poultry Specialist

Regulatory and Environmental Affairs Division Moorefield, West Virginia

April 2002 - September 2003

Environmental Specialist West Virginia Conservation Agency

Charleston, West Virginia

August 2000-April 2002

Poultry Service Technician

Perdue Farms, Inc

Salisbury, Maryland 